\title{
Plant uptake, translocation and metabolism of PBDEs in plants of food and feed industry: A review
}

\author{
Daniel Dobslaw (1D · Christine Woiski · Martina Kiel (D) Bertram Kuch • \\ Jörn Breuer (1)
}

Received: 7 August 2020/Accepted: 17 October 2020/Published online: 9 November 2020

(C) The Author(s) 2020

\begin{abstract}
Polybrominated diphenyl ethers (PBDEs) have widely been used for decades as flame retardants in a variety of products like plastics for building insulation, upholstered furniture, electrical appliances, vehicles, aircrafts, polyurethane foams, textiles, cable insulation, appliance plugs and various technical plastics in concentrations of 5-30\%. However, PBDEs also act as endocrine disrupters, neurotoxins, and negatively affect fertility. In 2001, worldwide consumption of technically relevant penta-BDEs was still estimated at 7500 tons, octa-BDEs at 3790 tons, and deca-BDE at 56,100 tons, but $50-60 \%$ of this total volume are discharged into the environment via sewage sludge and its agricultural use alone. In addition, soils are ubiquitously contaminated by the gaseous or particle-bound transport of PBDEs, which today has its main source in highly contaminated electronic waste recycling sites. The emitted PBDEs enter the food chain via uptake by the plants' roots and shoots. However, uptake and intrinsic transport behaviour strongly depend on crop specifics and
\end{abstract}

D. Dobslaw $(\bowtie) \cdot$ C. Woiski · M. Kiel · B. Kuch Department of Biological Waste Air Purification, Institute of Sanitary Engineering, Water Quality and Solid Waste Management, University of Stuttgart, Bandtäle 2, 70569 Stuttgart, Germany

e-mail: daniel.dobslaw@iswa.uni-stuttgart.de

J. Breuer

Center of Agricultural Technology Augustenberg,

76227 Karlsruhe, Germany various soil parameters. The relevant exposure and transformation pathways, transport-relevant soil and plant characteristics and both root concentration factors (RCF) and transfer factors (TF) as derivable parameters are addressed and quantified in this review. Finally, a simple predictive model for quantification of $\mathrm{RCF}$ and TF based on $\log \mathrm{K}_{\mathrm{Ow}}$ values and the organic content of the soil/lipid content of the plants is also presented.

Keywords Plant uptake - Translocation - Root concentration factor $\cdot$ PBDE - Shoot concentration factor $\cdot$ Food industry

\section{Application of PBDE and environmental relevance}

Polybrominated diphenyl ethers (PBDEs) were used as flame retardants for decades in multiple products like building insulations, upholstered furniture, electrical devices, vehicles and aircrafts, polyurethane foams, textiles, cable insulations, device plugs, and a large number of technical plastics (ABS, HIPS, PBT, PAP) in concentrations of 5-30\% (European Chemicals Bureau ECB 2003; Freudenschuß et al. 2008; Han et al. 2017). Even though 209 congeners of PBDEs exist, there were only three technical mixtures of PBDEs of commercial interest, named 
pentabromodiphenyl ether (penta-BDEs), octabromodiphenyl ether (octa-BDEs), and perbrominated diphenyl ether (deca-BDE). The global demand (EU demand) of penta-BDEs, octa-BDEs, and deca-BDE in 2001 was about 7500 tons (EU: 150 tons), 3790 tons (EU: 610 tons), and 56,100 tons (EU: 7600 tons), respectively (BSEF Bromine Science and Environmental Forum 2003). In 2003-2006 the annual consumption of BDE-209 reached 30,000 tons (China), 9600 tons (EU), 5000-10,000 tons (Northern America), and 1600 tons (Japan) (ECHA European Chemicals Agency 2015).

Besides their endocrine-disrupting properties, neurotoxicity, and negative impacts on fertility, the use of these PBDE mixtures was strictly regulated by the Stockholm Convention of 2001 due to their high degree of bromination and their classification as persistent organic pollutants (POPs). As acute toxicity of PBDEs declines by increasing degree of bromination (Sun et al. 2020), penta-BDEs and octa-BDEs were firstly banned in 2004, and deca-BDE was finally restricted in March 2019. At present, the use of deca$\mathrm{BDE}$ is severely restricted to the production of spare parts of cars, trucks, and aeronautic vehicles (European Commission EC 2017).

As high-volume chemicals used in multiple applications and due to their both gaseous and particulatebased atmospheric transport, PBDEs are ubiquitous, but mainly detectable in soil and dust samples of China, where $70 \%$ of the global e-waste as the main source of PBDEs are recycled (Stone 2009), and in waste water treatment sludges as the second main source (Venkatesan and Halden 2014). At these e-waste recycling sites the highest BDE-209 concentration levels ever listed were described by Han et al. (2017), namely 6.3-12,194.6 $\mathrm{ng} \mathrm{g} \mathrm{DM}^{-1}$ at a ratio of $64.2-89.6 \%$ of the total PBDE ( $\sum$ PBDE). At levels of 2720-4250 ng $\mathrm{g} \mathrm{DM}^{-1}$ of $\sum$ PBDE at a BDE-209 ratio of $35-82 \%$ and at $\sum$ PBDE levels up to 2000 ng g DM ${ }^{-1}$ similar concentration levels were previously described (Leung et al. 2007; Zhang et al. 2015). Moreover, the currently highest $\sum$ PBDE levels in soil were quantified as $8.70-18,451 \mathrm{ng} \mathrm{g} \mathrm{DM}^{-1}$ by $\mathrm{Xu}$ et al. (2019) at a production site for plastic parts in electrical industry in Changzhou. The same study revealed the currently highest measured dust concentrations of PBDEs with 7240-10,469 $\mathrm{ng} \mathrm{g} \mathrm{DM}^{-1}$ in an industrial environment, while concentrations of even 180-370,000 $\mathrm{ng} \mathrm{g} \mathrm{DM}^{-1}$ and
270-110,000 ng $\mathrm{g} \mathrm{DM}^{-1}$ were detected in house dust and office dust samples in the UK (Tao et al. 2016).

The study of Hale et al. (2012) focused on the BDE209 levels in sludges of waste water treatment plants (WWTPs) of 75 US WWTPs. It was detected at an average concentration of $2310 \mathrm{ng} \mathrm{g} \mathrm{DM}^{-1}$ with a top level of 15,500 $\mathrm{ng} \mathrm{g} \mathrm{DM}^{-1}$ at a WWTP in Chicago. A similar study at 15 Hessian WWTPs revealed $\sum$ PBDE levels of $85.5-5856 \mathrm{ng} \mathrm{g} \mathrm{DM}^{-1}$ in aerated sludges and $140.84-14,816 \mathrm{ng} \mathrm{g} \mathrm{DM}^{-1}$ in excess sludges (Leisewitz et al. 2003), but record setting levels of $2.5 \mathrm{w} \%$ were observed in sewage sludge of an industrial wastewater treatment plant in Turkey (Demirtepe and Imamoglu 2019). The annual input of PBDEs into the US environment in 2001 was quantified as 47.9-60.1 tons, where 24.0-36.0 tons per year were set free by agricultural use of sewage sludges (Venkatesan and Halden 2014).

As WWTP sludges are used as fertilizers in agriculture PBDE contaminations in the environment are not restricted to hotspots like e-waste sites and are finally ubiquitous due to the gaseous and particulatebased transport of PBDEs. Consequently, soil samples were positively tested towards PBDE contaminations in grassland and forest soils of the UK and Norway ( PBDE: 65-12,000 pg g DM ${ }^{-1}$, (Hassanin et al. 2004), Western Austria ( $\mathrm{PPBDE}$ : 10.4-2744 pg g DM ${ }^{-1}$, (Freudenschuß et al. 2010), Germany (BDE-47: $<27-505$ pg g DM ${ }^{-1}$, BDE209: < 156-461 pg g DM ${ }^{-1}$, (Dreyer et al. 2018), and Artic ( $\sum 12 \mathrm{PBDEs}$ ex BDE-209: $120 \mathrm{pg} \mathrm{g} \mathrm{DM}^{-1}$, (Dreyer et al. 2018); ¿PBDE: 1.7-416 pg g DM ${ }^{-1}$, (Zhu et al. 2015).

In consequence of the restrictions in use of PBDEs, alternative brominated flame retardants like hexabromobenzene, pentabromotoluene, 1,2-bis(2,4,6-tribromophenoxy)ethane, decabromo diphenyl ethane, or chlorinated ones as Dechlorane Plus were introduced in the past decades. Their annual global production was about 100-180 kilotons in 2008 (Law et al. 2013). As these alternatives show similar degrees of bromination, high persistency and bioaccumulation potentials are expected (Liagkouridis et al. 2015; Zhu et al. 2018). A ubiquitous presence of these compounds was already proven by She et al. (2013). 


\section{Physical characteristics and their effect on transport pathways and plant uptake}

PBDEs cover diphenyl ethers with a wide range of 2-10 bromo substituents. Hence, PBDEs reveal a large range of molar masses (328-959 $\mathrm{g} \mathrm{mol}^{-1}$ ), heterogeneous lipophilicity $\left(\log \mathrm{K}_{\mathrm{OW}}=6-10\right)$, and volatility $\left(\log \mathrm{K}_{\mathrm{OA}}=9-16\right.$; (She et al. 2013; Zhu et al. 2018) as well. Therefore, BDE congener specific transport and plant uptake mechanisms (soil-air-plant vs. soil-soil moisture-root-plant) strongly differ and depend on compound physical parameters (vapor pressure, $\mathrm{K}_{\mathrm{OW}}$ value, $\mathrm{K}_{\mathrm{OA}}$ value, Henry coefficient, air to plant distribution coefficient), meteorological parameters (temperature, wind velocity, rainfall, temporal rainfall distribution, deposition kinetics of gaseous BDEs, deposition kinetics of particulate BDEs), long range transport, plant specific characteristics (species, lipid content, carbohydrate content, fiber content, leaf morphology, non-lipid plant parts, bark consistency), and rhizosphere parameters (Klinčić et al. 2020; Yogui et al. 2011; Zhao et al. 2009; Zhu et al. 2015). Under aspects of transport, low brominated BDEs $\left(\mathrm{Br}_{2}-\mathrm{Br}_{3}\right)$ are mainly and medium brominated BDEs $\left(\mathrm{Br}_{4}-\mathrm{Br}_{5}\right)$, depending on the study, are minorly to dominantly distributed as gaseous compounds (BDE-15: 100\%; BDE-28: 35-60\%), while transmission and deposition of higher brominated congeners $\left(\mathrm{Br}_{6}-\mathrm{Br}_{10}\right)$ are obligatorily characterized by adsorption of BDEs on a particulate phase (Dreyer et al. 2018; Gao et al. 2019; Yogui et al. 2011; Zhao et al. 2009; Zhu et al. 2020). Due to the lower-range transport of the particulate phase, spectrum and concentrations of BDEs in soil and plant samples taken out of densely populated regions are more or less in agreement with the BDE emission spectrum, while the spectrum of detected PBDEs in sparsely populated regions is dominated by low brominated congeners like BDE-47 (51.2\%) and BDE-99 (17.8\%; Zhao et al. 2009). The reduced ratio of high brominated BDEs in the PBDE pattern of soil samples was also shown by Han et al. (2017), where the ratio of BDE-209 declined from originally $64.2-89.6 \%$ of the $\sum$ PBDE at the e-waste site to $10.4-35.8 \%$ at a rural sampling site nearby. Additionally, a significant concentration gradient of $\sum$ PBDE from both densely populated to sparsely populated regions and from emission sites to adjacent regions can be observed. Similar results were observed in plant tissue samples of Ligustrum lucidum Ait (Graziani et al. 2019). Concentration levels in dust samples of 19 PBDEs were reported by Zhu et al. (2018) in China in the range of 4.33-71,000 $\mathrm{ng} \mathrm{g} \mathrm{DM}^{-1}$ at an average of

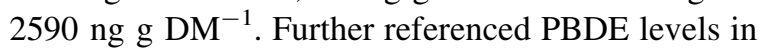
dust were in the range of 227-160,000 $\mathrm{ng} \mathrm{g} \mathrm{DM}^{-1}$ (South China; Wang et al. 2010), 6300-82,200 ng g DM ${ }^{-1}$ (East China; Ma et al. 2009), 320-290,000 ng g DM ${ }^{-1}$ (Thailand; Muenhor et al. 2010), 311-19,700 ng g DM ${ }^{-1}$ (USA; Schreder and La Guardia 2014), and 72-89,000 ng g DM ${ }^{-1}$ (UK; Harrad et al. 2010). Record setting levels of 180-370,000 ng g DM ${ }^{-1}$ were presented by Tao et al. (2016) in housing dust samples. Commonly, all studies revealed domination of BDE-209 ratio in the PBDE spectrum detected in dust and soil samples, i.e. BDE209: 69.2\%, BDE-196: 4.49\%, BDE-47: 4.40\%, other BDEs: $<3.00 \%$ as shown by Zhu et al. (2018). Even BDE-209 ratios of $90 \%$ (Zhu et al. 2020) and 93.2-99.6\% were reported (Tao et al. 2016).

Due to the high molar mass and the lipophilicity of high brominated BDEs, plant uptake by the soil-soil moisture-root-plant pathway is of low relevance and restricted to low and medium brominated BDEs $\left(\mathrm{Br}_{2}-\right.$ $\mathrm{Br}_{5}$ ) like BDE-47, BDE-99 and BDE-100 (Klinčić et al. 2020; Mueller et al. 2006). Nevertheless, high brominated BDEs $\left(\mathrm{Br}_{7}-\mathrm{Br}_{10}\right)$ like BDE-209 are detected in multiple plant samples, strengthening the hypothesis of adsorptive plant/shoot-uptake via the atmospheric pathway, even though BDE-209 revealed a low ratio of $0.1 \%$ of the total atmospheric PBDE pattern (Li et al. 2015b) due to high deposition rates of 120-137,000 pg PBDE m ${ }^{-2} \mathrm{~d}^{-1}$ (Zhan et al. 2019). Single studies delivered hints for intrinsic transport of BDE-209 in plants (Chow et al. 2015; Vrkoslavová et al. 2010; Zhao et al. 2017b). However, differentiation between intrinsic BDE-209 and BDE-209 adsorbed at the outer side of the roots/plant tissue is sophisticated. Plant availability of BDE-209 was quantified as $0.3-0.5 \%$ of the initial concentration set in the experimental setup of Wu et al. (2018b), i.e. 99.5-99.7\% of BDE-209 are solely adsorbed on soil matrix or the outer side of the roots. Hence, atmospheric uptake of high brominated BDEs is the dominant pathway (Gao et al. 2019). 


\section{Human exposure to PBDE contaminations and uptake}

Despite atmospheric PBDE plant uptake and subsequent use of plants as food, human PBDE uptake is dominated by inhalation of both gaseous and particulate PBDEs. The relevance of both pathways strongly depends on the contamination of the cultivation area and the place of residence, i.e. they are of low relevance in case of low contaminated regions, but might get highly relevant in case of contaminated regions next to industrial sites. Studies of Hites and Sjödin et al., scoping on the atmospheric 5 PBDE levels, revealed concentrations of 5.27-301 $\mathrm{pg} \mathrm{m}^{-3}$ in ambient air and $0.08-67 \mathrm{ng} \mathrm{m}^{-3}$ at indoor air, but increased levels of up to $312.1 \mathrm{ng}$ BDE-209 $\mathrm{m}^{-3}$ at a Swedish e-waste recycling site (Hites 2004; Sjödin et al. 2001). Average BDE-209 levels of $0.13 \mathrm{ng} \mathrm{m}^{-3}$ (gaseous BDE-209) and $140 \mathrm{ng} \mathrm{m}^{-3}$ (particulate BDE-209) were detected in 14 Chinese air samples of a wide spectrum of locations, pointing out the high relevance of inhalative human uptake in China $(\mathrm{Li}$ et al. 2015a). Here, the daily human uptake of BDE209 was calculated as $570 \mathrm{ng} \mathrm{d}^{-1}$ (food), $3000 \mathrm{ng} \mathrm{d}^{-1}$ (respiration), and $69 \mathrm{ng} \mathrm{d}^{-1}$ (dust uptake), i.e. $84 \%$ of the daily uptake takes place by gaseous and particulate PBDE uptake, but is clearly dominated by particulate uptake (Fraser et al. 2009; Johnson-Restrepo and Kannan 2009; Klinčić et al. 2020; Lorber 2008; Schecter et al. 2006; Stapleton et al. 2008; Wu et al. 2007). At a ratio of $16 \%$, uptake by food is the second dominant pathway.

At lower ambient PBDE levels dietary intake gets the dominant pathway, especially in case of high lipid content (European Food Safety Authority EFSA 2011; Martellini et al. 2016). Therefore, dietary intake is of high relevance for strategies in reduction of human PBDE uptake.

\section{Detoxification mechanisms of PBDEs}

\subsection{Transformation of PBDE in soil and sediments}

Transformation behavior of PBDEs in soil and sediments strongly depends on the degree of bromination and the concentration of oxygen, organic matter and microorganisms in these compartments as well. In general, low brominated compounds tend to be degraded under aerobic conditions, while high brominated compounds are mainly degraded under anaerobic conditions (Zhu et al. 2014c). This correlation was previously described in degradation of chlorinated compounds (Han et al. 2017; Pimviriyakul et al. 2020; Reineke et al. 2002). PBDEs are either mineralized by stepwise debromination or detoxified by hydroxylation or methoxylation reactions in the rhizosphere. Hence, Han et al. (2017) observed the formation of hydroxylated (OH-PBDE) and methoxylated (MeOPBDE) transformation products of BDE-209 and other PBDEs in soil samples under aerobic conditions at levels of $1-22 \mathrm{ng} \mathrm{g}^{-1} \mathrm{DM}$ ( $\left.\sum \mathrm{OH}-\mathrm{PBDE}\right)$ and 0.04-0.3 $\mathrm{ng} \mathrm{g}^{-1} \mathrm{DM}$ ( $\left.\sum \mathrm{MeO}-\mathrm{PBDE}\right)$. Hydroxylated transformation products were also observed for hydrophilic PBDEs like BDE-3 (Yao et al. 2020) or BDE-47 (Wang et al. 2019a).

Bacterial debromination of PBDEs in soil and sediments was shown by different authors (Chen et al. 2015, 2017; Farzana et al. 2019b; Hale et al. 2012; Wang et al. 2020; Zhao et al. 2017b; Zhu et al. 2014b, c). Transformation intermediates of BDE-153 $\left(\mathrm{Br}_{6}\right)$ were analyzed by $\mathrm{Zhu}$ et al. in eight different sediments revealing formation of lower brominated transformation products $\left(\mathrm{Br}_{1}-\mathrm{Br}_{6}\right)$ under anaerobic conditions and, contrarily, negligible transformation under aerobic conditions (Zhu et al. 2014b). A second study by these authors focusing on BDE-47 and BDE209 quantified conversion rates as $92-93.4 \%$ (BDE47) and less than 5\% (BDE-209) under anaerobic conditions at initial concentrations of $5000 \mathrm{ng} \mathrm{g}^{-1}$ DM, underlining the poor biodegradability of high brominated BDEs (Zhu et al. 2014c). Nevertheless, bacterial species of the genera Achromobacter, Burkholderia, Dehalobacter, Dehalococcoides, Dehalogenimonas, Geobacter, Microbacterium, Rhodococcus, Sphingomonas, and Sulfurospirillum are known for PBDE degradation potentials (Chen et al. 2015, 2017; Deng et al. 2016; Wang et al. 2019a; Yu et al. 2020; Zhu et al. 2014b).

\subsection{Transformation of PBDE in the gas phase}

Transformation of PBDEs by atmospheric reactions was also observed by multiple authors. Exemplarily, Ueno et al. detected OH-PBDEs in different Canadian abiotic surface waters, fresh snow and rainfall samples (Ueno et al. 2008). The authors suggested photolytic transformation of atmospheric PBDEs (gaseous and 
particulate) to their corresponding OH-PBDEs and subsequent transformations to lower brominated congeners. Kuch et al. (2005) observed the ring closure to the corresponding dibenzofurans and hydrodebromination to less brominated transformation products as the dominant reactions during UV exposure of PBDEs.

\subsection{Transformation of PBDE in plants}

Intrinsic PBDEs can be transformed by debromination, hydroxylation and methoxylation reactions mainly in the shoots of the plants as well, similar to microbial transformation reactions in soil and sediments. In the study of Huang et al. (2010) 19 different plants were initially spiked with BDE-209 via the soil phase. As transformation products lower brominated BDEs $\left(\mathrm{Br}_{2}-\mathrm{Br}_{9}\right)$ and five different $\mathrm{OH}-\mathrm{BDEs} / \mathrm{MeO}-$ BDEs were detected in the plant tissue. However, the concentration of microorganisms in the soil phase increased in parallel, particularly complicating the interpretation of the results. The ratio of $\mathrm{Br}_{2}$-BDEs up to $\mathrm{Br}_{5}$-BDEs in the plant tissue was elevated in comparison to the soil (7.3-21.1\% vs. $6.5-12.2 \%$ ), and hydroxylation/methoxylation products were solely detected in the plant tissues, from which the authors concluded that, besides soil based microbial debromination reactions, an additional transformative turnover of PBDEs in the plant tissue took place. Further studies showed similar interpretations (Deng et al. 2016; Hu et al. 2020; Xu et al. 2016). This conclusion was also verified by Wang et al. (2012) focusing on transformation of BDE-28 and BDE-47 in maize. Potential microbial as well as adsorptive aspects were excluded by hydroponic cultivation. Under these conditions, BDE-47 $\left(\mathrm{Br}_{4}\right)$ was transformed in the root phase dominantly to 6-MeO-BDE-47 (275 $\left.\mathrm{ng} \mathrm{g}^{-1} \mathrm{DM}\right)$, followed by 5 -MeO-BDE-47 (40 $\left.\mathrm{ng} \mathrm{g}^{-1} \mathrm{DM}\right)$, $\sum \mathrm{Br}_{2}$-BDEs $\quad\left(23 \mathrm{ng} \mathrm{g}^{-1} \quad \mathrm{DM}\right), \quad \sum \mathrm{Br}_{3}$-BDEs (20 $\left.\mathrm{ng} \mathrm{g}^{-1} \mathrm{DM}\right)$, and minor amounts of two unknown hydroxylated BDEs ( $\left.8 \mathrm{ng} \mathrm{g}^{-1} \mathrm{DM}\right)$ during the first 48-96 $\mathrm{h}$ after exposure. However, the total content of PBDEs and brominated intermediates was lower than the initial concentration by a factor of 2-3 and further declined with experimental progress, i.e. BDE-47 was mineralized. Similar results were also observed for BDE-28 $\left(\mathrm{Br}_{3}\right)$. Thus, the parallel presence of debromination, hydroxylation and methoxylation was demonstrated. Furthermore, these reactions mainly took place in the plants' stems and shoots and were of minor relevance in the root fraction. Similar conclusions were also drawn by Pan et al. (Pan et al. 2016) for transformation of BDE-99 in rice, wheat, and soy plants in hydroponic cultivation, where O-methylation was again the dominant transformation mechanism. The level of the reverse reaction of $\mathrm{x}-\mathrm{MeO}-\mathrm{BDE}-99$ to $\mathrm{x}$-HO-BDE-99 $(\mathrm{x}=5,6)$ was $1-2$ log units lower.

Debromination behavior of PBDEs in plants and quantification of corresponding congeners as intermediates were particularly demonstrated by She et al. (2013) for rice (conversion of BDE-209), by Zhao et al. (2012) for maize (conversion of BDE-28, BDE47, and BDE-99) and for Scirpus validus by Zhao et al. (2017b). The detected intermediates represented only a minority of the initial PBDE levels. Thus, supported by microbial biotransformation processes, PBDEs were mainly mineralized.

In contrast, various studies showed almost unchanged concentrations of PBDEs over the total test period or comparable PBDE patterns both in soil and plant tissues due to negligible or low metabolism of PBDEs in soil and roots (Venkatesan and Halden 2014; Yang et al. 2008). In agreement with the former issues, Chen et al. postulated the high relevance of the established rhizosphere in degradation of PBDEs (Chen et al. 2015).

In summary, PBDEs in plants are transformed by debromination, hydroxylation and methoxylation reactions. However, plant uptake and transformation behavior strongly depend on the plant species and the established microbial consortium in the rhizosphere.

\section{Soil-root transport: RCF and TF value}

\subsection{RCF value of PBDEs}

Besides the atmospheric pathway, uptake of low brominated and, thus, hydrophilic PBDE congeners may also take place by the soil-soil moisture-root pathway. This pathway was exemplarily proven by Zhao et al. in maize (2012), where a clear concentration gradient of low brominated PBDEs was observed over the height of the plant. Contrarily, high brominated PBDE show low mobility in root based PBDE uptake due to the high lipophilicity of these compounds. The mobility as core aspect of PBDE plant uptake was clearly shown by Freudenschuß et al. 
(2008) and Cheng et al. (2014) in soil samples, where concentration of low brominated congeners increased by soil depth, but decreased in case of high brominated compounds.

Even more, high brominated PBDEs are strongly adsorbed to soil particles or the outer root phase. In case of BDE-209 only $0.3-0.5 \%$ of the concentration present in soil is available to plants (Wu et al. 2018b). Hence, this pathway is of low relevance but still present as shown by BDE-209 levels 3.5-6 times higher in living roots of different plants than in nonliving samples (Chow et al. 2017) or by small-scale soil based BDE gradients within the root zone (Száková et al. 2019). BDE-209 uptake by roots even might be the dominant pathway at high soil contamination levels or hydroponic cultivation (Zhang et al. 2015). This statement was clearly evidenced by greenhouse experiments of Huang et al. (Huang et al. 2010). Here, BDE-209 levels of plants were examined during parallel cultivation in either noncontaminated or contaminated soil. Levels reached 5.2-10.4 ng g DM ${ }^{-1}$ of BDE-209 in six different plant species cultivated in non-contaminated soil, which was less than 5\% of the BDE-209 concentrations detected in the same species cultivated under contaminated conditions, i.e. more than $95 \%$ of BDE209 contamination in plants could be attributed to plant uptake and intrinsic plant transport. Both processes were shown to be coupled to plant transpiration by Zhao et al. (2012). Hot as well as dry weather conditions, which increase plant transpiration, may thus be connected to elevated PBDE levels in shoots and leaves of the plants.

To increase comparability of PBDE uptake and intrinsic transport, both the root concentration factor (RCF) and the translocation factor (TF) were introduced in literature and correlated to the log $\mathrm{K}_{\mathrm{Ow}}$ value of PBDEs. As a conclusion and in difference to PCBs, there is a strong negative correlation of the $\log \mathrm{K}_{\mathrm{OW}}$ value and the RCF, i.e. higher RCF values were detected in case of lower brominated PBDEs and, therefore, compounds with lower log $\mathrm{K}_{\mathrm{OW}}$ values than in case of higher $\log \mathrm{K}_{\mathrm{Ow}}$ values (Zhang et al. 2015). In detail, the plant specific RCF of BDE-209 was up to ten times lower than the RCF of BDE-28 (Han et al. 2017; She et al. 2013; Zhang et al. 2015). This effect may be explained both by the lack of water solubility and, therefore, restricted root uptake with the soil moisture phase, and the strong adsorption of higher brominated PBDE on the soil phase. Furthermore, a serious inhibition of PBDE uptake was observed in case of high concentration levels (Pier et al. 2002).

In difference, a positive correlation of the $\log \mathrm{K}_{\mathrm{ow}}$ value with both the RCF and the TF was observed for maize with increasing height of the plants solely in case of the low brominated BDE-15, BDE-28, and BDE-47 (Wang et al. 2011c; Zhao et al. 2012). This effect was explained by PBDE concentrating caused by plant transpiration and, therefore, increasing water losses in the shoots of the plants.

\subsection{RCF value of plants for bioremediation}

The plant ability of PBDE accumulation at high RCFs is technically used in phytoremediation processes. Radish, green squash, and S. validus were previously described in PBDE phytoremediation of $\mathrm{Br}_{5}$-BDEs (radish, green squash) and $\mathrm{Br}_{4}-\mathrm{BDEs}$ to $\mathrm{Br}_{7}$-BDEs ( $S$. validus) at RCFs of even 1 or higher. RCFs of nearly 0.1 were achieved in case of lipophilic BDE-206 and BDE-207 in this study (Zhao et al. 2017b). High phytoremediation potentials, further enhanced by inoculation of the rhizosphere with Bacillus cereus JP12, were also described for Sedum alfredii as a herb, and for Festuca arundinacea as a grass (Lu and Zhang 2014). Initial concentrations of $4870 \mathrm{ng} \mathrm{g}^{-1} \mathrm{DM}$ of BDE-209 were diminished by a factor of 15 reaching final levels of $320 \mathrm{ng} \mathrm{g}^{-1} \mathrm{DM}$ within 120 days. In general, with exception of these plants for phytoremediation, RCFs of clearly less than 1 and a negative correlation of RCF and $\log \mathrm{K}_{\mathrm{OW}}$ values might be expected.

\subsection{Effect of solubilizers}

Plant availability and, therefore, plant uptake of adsorbed PBDEs might be enhanced in presence of native plant extracts or by injection of artificial solubilizers into the soil phase. Solubilization efficiencies of BDE-209 by different solubilizers were analyzed by Zhao et al. (2017a). Here, the cationic solubility promotor cetyltrimethylammonium bromide (CTAB), sodium dodecyl sulfate (SDS) as anionic solubility promotor, and both Tween 80 and $\beta$-cyclodextrin as non-ionic solubilizers were tested either as sole compounds or in mixture with each other. While the addition of the solubilizers did not lead to negative effects on plant growth, enhanced 
plant uptake of BDE-209 was only observed in case of CTAB, SDS, or Tween 80 , but not for $\beta$-cyclodextrin. This finding is contradicted by the study of $\mathrm{Li}$ et al. (2018a), which investigated the elimination of BDE209 by planting amaranth (Amaranthus hypochondriacus) with the optional additional inoculation of the soil samples with a mycelium or $0-1.2 \mathrm{w} \%$ of $\beta$ cyclodextrin. While the BDE-209 levels in the control sample solely planted with amaranth smoothly declined from $2200 \mathrm{ng} \mathrm{g}^{-1} \mathrm{DM}$ to $2100 \mathrm{ng} \mathrm{g}^{-1} \mathrm{DM}$ during the test period, elimination was enhanced by application of the mycelium (1600 $\left.\mathrm{ng} \mathrm{g}^{-1} \mathrm{DM}\right)$ and also boosted in presence of $\beta$-cyclodextrin (750 $\mathrm{ng} \mathrm{g}^{-1} \mathrm{DM}$ ). Similar results were reported by $\mathrm{Li}$ et al. (2018b) in case of BDE-209 soil contaminations with Solanum nigrum as planting and optional application of mycorrhizal fungi Funneliformis mosseae or Rhizophagus intraradices, where initial BDE209 levels (4750 $\left.\mathrm{ng} \mathrm{g}^{-1} \mathrm{DM}\right)$ strongly declined to final levels of $2250 \mathrm{ng} \mathrm{g}^{-1}$ DM during operation time.

The same tendency-but with clearly more relevance for practice-was reflected by a study of Li et al. (2019c) that examined the effect of extracts from wheat straw or pig manure on BDE-47 uptake in wheat plants. Here, uptake increased by a factor of 3.1 (wheat straw) and 1.9 (pig manure). The addition of a solubilizer without pronounced surfactant properties that simply increases the organic content of the soil leads to a contrary effect. In this case an increased accumulation of PBDEs in the soil phase and a reduced plant uptake efficiency was observed (Cheng et al. 2014; Xiang et al. 2019b).

\subsection{Additional parameter affecting the $\log \mathrm{K}_{\mathrm{OW}^{-}}$ RCFs correlation}

As listed before, both positive and negative correlations between $\log \mathrm{K}_{\mathrm{OW}}$ and RCFs were observed. Potential explanatory approaches therefore refer to plant species specifics during accumulation and translocation of PBDEs, to differences in physical and chemical soil properties (see Sect. 6), variations of several orders of magnitude in pollutant concentrations, and the simultaneous, but hardly distinguishable, soil-air-plant uptake pathway. Especially the duration of the growth period of the cultivated plants (Gao et al. 2019; She et al. 2013) and the organic soil content (see Sects. 6, 7) showed considerable impact on PBDE uptake. Particularly high RCF levels up to
30,000 were observed in case of hydroponic cultivation approaches due to the high lipophilicity of the PBDEs and parallel absence of lipophilic soil matter (Pan et al. 2016).

\subsection{TF values of PBDE}

Following uptake, intrinsic PBDE transport via the plant specific water transport systems takes place. The concentration ratio of PBDE levels in the shoots to the levels in the roots is referred to as translocation factor (TF). A general statement about the correlation of log $\mathrm{K}_{\mathrm{OW}}$ and $\mathrm{TF}$ values is not appropriate, since no clear positive or negative correlation was found. The TF value depends on species specifics, the lipid content of the shoots, the plant age, the distance of the plant tissue from the root plexus, as well as numerous other parameters, which are partly insufficiently determined. According to Zhang et al. the PBDE concentration in the soil phase is of particular relevance (Zhang et al. 2015). Examining rice plant samples, the authors observed a negative correlation of $\log \mathrm{K}_{\mathrm{OW}}$ and TF values at low concentration levels $\left(\sum \mathrm{PBDE}=130 \mathrm{ng} \mathrm{g}^{-1} \mathrm{DM}\right)$, but this correlation turned to positive in case of high PBDE levels $\left(\sum \mathrm{PBDE}=2000 \mathrm{ng} \mathrm{g}^{-1} \mathrm{DM}\right)$. A clear quantification of the TF values is further complicated by the simultaneous soil-air-plant exposure pathway, potentially falsifying the detected concentrations. In principle, a negative correlation may be assumed, i.e. with increasing degree of bromination and therefore increasing $\log \mathrm{K}_{\mathrm{OW}}$ values a decreasing mobility and thus an accumulation of PBDEs in the root area is expected. Hence, stem and shoots show significant lower contamination levels and relevance of atmospheric PBDE uptake significantly increases (Zhao et al. 2012). The bioaccumulation and translocation behavior of PBDEs in plants is not conclusively clarified and depends on numerous, partially insufficiently determined parameters.

In summary, it can be stated that RCF and TF values in plants-besides species specifics-depend on multiple parameters like organic content and heavy metal content in the soil. The effect of various soil parameters on PBDE uptake is examined in more detail in the following section. The phenotypic effect of uptake or translocation of PBDEs is often not yet understood, i.e. bioaccumulation and translocation behavior of 
PBDEs in plants is not conclusively clarified and needs further investigations.

\section{Factors of PBDE plant uptake}

Various studies have looked at the physico-chemical properties of soils and the substance-specific properties of PBDEs with regard to plant uptake and biodegradation behavior. For dispersion, PBDE specifics (vapor pressure, $\mathrm{K}_{\mathrm{OW}}$ value, air-water distribution $\mathrm{K}_{\mathrm{AW}}$ value, air-plant distribution $\mathrm{K}_{\mathrm{AP}}$ value), environmental factors (temperature, wind speed, amount of rain, temporal rain distribution, kinetics of gas deposition, kinetics of particle-bound deposition), plant properties (species, lipid content, leaf morphology, ratio of non-lipid plant parts, thickness of the bark, sugar content, fiber content), as well as the presence of an active rhizosphere are commonly of high relevance. For bioavailability and thus biodegradability of PBDEs $\mathrm{pH}$ value and soil composition are of particular importance (Yogui et al. 2011; Zhao et al. 2009; Zhu et al. 2015). In detail, relevant parameters are:

\subsection{Excretion of plant solubilizers}

In order to prevent potentially toxic or inhibitory accumulation of PBDEs, some plants pursue the strategy of excreting easily metabolizable intermediates as solubilizers into the rhizosphere that facilitate microbial biodegradation of PBDEs (Zhao et al. 2017b). According to the authors, such compounds could be amino acids, organic acids, sugars and exoenzymes to improve the bioavailability and thus the microbial degradability of BDE-209. However, the authors did not provide direct evidence for this hypothesis. The proof was finally provided by Farzana et al. (2019b), where addition of $620 \mathrm{mg} \mathrm{L}^{-1}$ of hexose both enhanced microbial debromination of BDE-99 to $\mathrm{Br}_{2}$-BDEs and $\mathrm{Br}_{3}$-BDEs in soil and uptake of PBDEs into Kandelia obovate.

\subsection{Plant specifics}

Behavior of PBDE plant uptake is fundamentally plant-specific and particularly defined by plant morphology. Exemplarily, Zhao et al. (2009) found that the wax layer of bay leaves leads to an increased uptake of both particulate-bound and gaseously transported PBDEs. A similar correlation between the age dependent lipid content of leaf and the atmospheric PBDE exposure was also established by Gao et al. (2019). Zhu et al (2020) quantified the accumulation of $\mathrm{Br}_{3}$-BDEs to $\mathrm{Br}_{10}$-BDEs in the wax layer of wheat to $29-93 \%$ of the total plant uptake.

In case of the soil-soil moisture-plant pathway a strong plant-specific accumulation of PBDEs in the plant tissue was observed by Huang et al. (2010). In pot experiments with six different plant species and an initial concentration of $4700 \mathrm{ng} \mathrm{g}^{-1}$ DM of BDE-209, soil levels declined by $12.1-38.5 \%$ after 60 days of cultivation, while plant levels specifically increased, i.e. PBDE levels reached 1822 ng plant $^{-1}$ as lowest level in alfalfa and 10,933 $\mathrm{ng}_{\text {plant }}{ }^{-1}$ as the highest level in maize. Formation of plant eluates to enhance formation of the microbial microflora, biodegradation, as well as detoxification of PBDEs in the soil phase was postulated for single plant species by Wang et al. (2014).

\subsection{Rhizosphere and mycorrhiza}

The release of plant eluates is part of the symbiosis between the plant and the mycorrhizal fungi promoting the plant's uptake of nutrients and growth of microorganisms in the mycorrhizal area. The positive effects on biodegradation and detoxification were proven by Eggerstedt-Lehmann (2005) for petroleumderived hydrocarbons and by $\mathrm{Li}$ et al. $(2018 \mathrm{a}, \mathrm{b})$ for amaranth and black nightshade by application of mycorrhizal fungi Funneliformis mosseae or Rhizophagus intraradices. Compared to reference plants without fungi an increased depletion of $4750 \mathrm{ng} \mathrm{g}^{-1}$ DM to $2250 \mathrm{ng} \mathrm{g}^{-1}$ DM of BDE-209 was observed. Similar results were presented by Feng et al. (2019).

\subsection{Specific root and leaf surface}

The lipophilicity of PBDEs mainly evokes adsorption and accumulation of soil based PBDEs at the outer root surface. A potential connection between increased inner root accumulation of PBDEs and high specific root surface was postulated by Wang et al. (2014), but no final proof could be provided. The final evidence was provided for the radish Raphanus sativus L. by Yang et al. (2017) and for lettuce, radish and taro by Wang et al. (2016a, b) for BDE-209. 
Additionally, this evidence was provided by Tian et al. (2012) for atmospheric transport and plant uptake by the leaf surface. Quantification of $\mathrm{Br}_{2}-\mathrm{BDE}$ to $\mathrm{Br}_{10}-\mathrm{BDE}$ in both pine needles and eucalyptus leaves and the dust particles adsorbed on them revealed $\sum$ PBDE levels higher by a factor of 2.3 in the needles $\left(148 \mathrm{ng} \mathrm{g}^{-1} \mathrm{DM}\right)$ than the leaves (64.1 $\mathrm{ng} \mathrm{g}^{-1} \mathrm{DM}$ ), even though both plants have comparable lipid contents in their foliage (pine: $82 \mathrm{mg} \mathrm{g}^{-1} \mathrm{DM}$; eucalyptus: $77 \mathrm{mg} \mathrm{g}^{-1} \mathrm{DM}$ ). However, this factor is reflected in the specific surface area of the foliage (pine: $17.2 \mathrm{~m}^{2} \mathrm{~kg}^{-1}$; eucalyptus: 5.8 $\mathrm{m}^{2} \mathrm{~kg}^{-1}$ ).

\subsection{Lipid content}

The lipid content of a plant, especially the root, has a strong impact on PBDE uptake characteristics and has been evaluated for various mosses and lichens as well as rice (Huang et al. 2010; She et al. 2013; Yogui et al. 2011). Huang et al. and recently Jian et al. (2020) found a direct correlation between the lipid content and both RCF value and TF value analyzing 6 and 11 plants of different lipid content, respectively (see Fig. 1), i.e. a higher lipid content leads to a lower intrinsic PBDE mobility and thus to a negative correlation with the TF value. According to additional atmospheric transport, Tian et al. pointed out the influence of the specific surface of the foliage (Tian et al. 2012).

\subsection{Organic content of the soil}

Similar to the lipid content of plants, increasing organic content of the soil evokes higher PBDE accumulation in the soil phase and thus reduced PBDE plant uptake (Cheng et al. 2014; Xiang et al. 2018; Zhao et al. 2017b; Zhu et al. 2014a, 2018). In case of sediments in mangroves, BDE-209 reached levels of $25 \mathrm{ng} \mathrm{g}^{-1} \mathrm{DM}$ and $200 \mathrm{ng} \mathrm{g}^{-1} \mathrm{DM}$ in the sediments at $7 \%$ and $20 \%$ of organic content, respectively (Zhu et al. 2014a). Similar results were observed for BDE47 by Xiang et al. $(2018,2019 a)$, where plant uptake in carrots was reduced by $31.5-69.8 \%$ by addition of $1-4$ w\% of swine manure to the soil fraction. Compared to the initial soil concentration of $384.5 \mathrm{ng} \mathrm{g}^{-1}$ DM the final BDE-47 level in soil without addition of organic matter was $121.1 \mathrm{ng} \mathrm{g}^{-1} \mathrm{DM}$ and was increased to $268.4 \mathrm{ng} \mathrm{g}^{-1} \mathrm{DM}$ at a $4 \%$ pig manure content. In parallel, PBDE biodegradation in soil increased by $8.6-28.5 \%$ (Xiang et al. 2018). Finally, Cheng et al. (2014) differentiated between TOC and DOC content and observed a clear improvement in adsorption of PBDEs in the soil matrix at higher TOC levels, whereas no effect was detected when increasing DOC levels. Due to enhanced biodegradation of PBDEs as co-substrate in the soil phase, both lower brominated congeners and lower total concentrations are therefore absorbed by the plants (Zhao et al. 2017b). This result was again validated for hydrophilic BDE-47 in presence of formiate, acetate, lactate, succinate, pyruvate, methanol or ethanol (Pan et al. 2020) and for hydrophilic BDE-209 after addition of pyrene (Li et al. 2020b).

\subsection{Biochar}

The admixture of pure or metal doped biochar to the soil phase strongly increased TOC levels and therefore affected PBDE uptake as investigated for Pak Choi (Brassica chinensis) by Wu et al. (2018a). BDE-209 and $\sum$ PBDE plant uptake were reduced by 240-270 $\mathrm{ng} \mathrm{g}^{-1} \mathrm{DM}$ or a factor of 2.5-2.7. In contrast, both adsorption and plant uptake of BDE153 were slightly increased by $5 \%$ in hydroponic culture (Jia et al. 2019), but this effect may have been caused by the high moisture content of the biochar.

\subsection{Sewage sludge}

In addition to liquid manure as agricultural fertilizer, the land application of sewage sludge is an important disposal method worldwide and allows substitution of mineral fertilizers. As sewage sludge reveals a high TOC content and enhanced contaminations with PBDEs or their detoxification and degradation products (Vrkoslavová et al. 2010), sewage sludge is a dominant exposure pathway. Until 2001, the annual environmental PBDE input in the USA was quantified as 47.9-60.1 tons, where 24.0-36.0 tons were associated with sewage sludge disposal (Venkatesan and Halden 2014). Hence, soil concentration levels and plant uptake of especially lipophilic PBDEs like BDE209 considerably increased in the range of 840-3900 $\mathrm{ng} \mathrm{g}^{-1} \mathrm{DM} \sum$ PBDE during sewage sludge application (Huang et al. 2010; Law et al. 2006; Sellström et al. 2005). Corresponding soil levels after sewage sludge disposal reached more than 

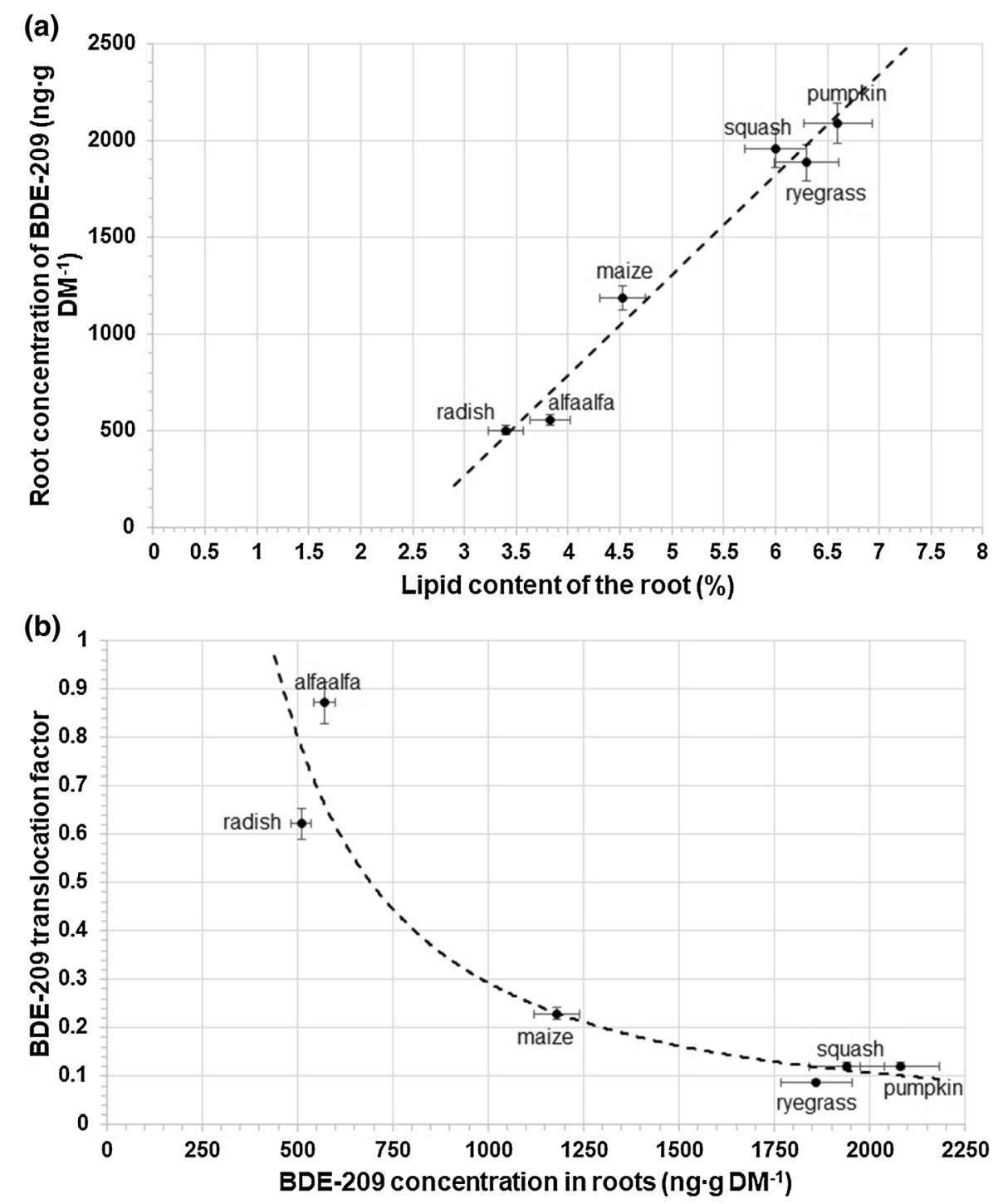

Fig. 1 a Correlation of BDE-209 concentration in roots and corresponding root lipid content (based on Huang et al. 2010). b Correlation of translocation factors and BDE-209 concentration in roots (based on Huang et al. 2010)

20,000 $\mathrm{ng} \mathrm{g}^{-1} \mathrm{DM} \sum \mathrm{PBDE}$ considering pre-contamination of the soil. Increases by $568 \mathrm{ng} \mathrm{g}^{-1} \mathrm{DM}$ and $400 \mathrm{ng} \mathrm{g}^{-1} \mathrm{DM}$ were observed for $\sum \mathrm{Br}_{5}-\mathrm{BDE}$ and BDE-209 in another study (Vrkoslavová et al. 2010). Published PBDE levels in different sewage sludge samples are summarized in Table 1. Similar to lipid levels, a negative correlation between BDE-209 uptake and organic content, implemented by sewage sludge output, was observed ( $\mathrm{Li}$ et al. 2015b). Moreover, BDE-209 soil levels declined by less than $5 \%$ during a 3-year test period as shown in Fig. 2 (Venkatesan and Halden 2014; Zhu et al. 2014c).

\subsection{Compost and digestate}

In addition to sewage sludge and liquid manure, compost and digestate are important materials for soil improvement. Due to the relatively low TF values and preceding RCF values of the plant educts (leaves, green waste, fruit and food residues), the PBDE load of compost and digestates is rather low as confirmed by various studies. In composts of Bavaria, Sweden and Switzerland median PBDE concentrations of $12 \mathrm{ng} \mathrm{g}^{-1} \mathrm{DM}, 2-21.6 \mathrm{ng} \mathrm{g}^{-1} \mathrm{DM}$ and $10 \mathrm{ng} \mathrm{g}^{-1}$ $\mathrm{DM}$ were measured, respectively (Amundsen et al. 
Table 1 PBDE levels in sewage sludge samples in $\mathrm{ng} \mathrm{g}^{-1} \mathrm{DM}$

\begin{tabular}{|c|c|c|c|c|c|}
\hline Location & No. of sites & BDE & Sludge type & Concentration & Source \\
\hline Northeast America & 48 & $\sum \mathrm{Br}_{5}$ & Excess sludge & Up to 1530 & Hale et al. (2012) \\
\hline Western America & No data & $\sum \mathrm{Br}_{5}$ & Excess sludge & Up to 2120 & Hale et al. (2012) \\
\hline Hesse & 15 & $\sum \mathrm{PBDE}$ & Activated sludge & $85.5-5856$ & Leisewitz et al. (2003) \\
\hline Hesse & 15 & $\sum \mathrm{PBDE}$ & Excess sludge & $140.84-14,816$ & Leisewitz et al. (2003) \\
\hline USA & 110 & $\begin{array}{l}\sum \text { PBDE } \\
\text { BDE-206 } \\
\text { BDE-207 } \\
\text { BDE-209 } \\
\varnothing \text { BDE-209 }\end{array}$ & Excess sludge & $\begin{array}{l}\text { Up to } 9400^{\mathrm{a}} \\
\text { Up to } 4350 \\
\text { Up to } 3530 \\
\text { Up to } 17,100 \\
5360\end{array}$ & Venkatesan and Halden (2014) \\
\hline Turkey & 4 & $\begin{array}{l}\sum \text { PBDE } \\
\text { BDE-209 }\end{array}$ & Dewatered sludge sample & $\begin{array}{l}44.0-2.46 \times 10^{7} \\
66.9-2.46 \times 10^{7}\end{array}$ & Demirtepe and Imamoglu (2019) \\
\hline $\begin{array}{l}\text { Baden- } \\
\text { Wuerttemberg }\end{array}$ & 22 & $\sum P B D E$ & Dewatered sludge sample & $77.7-338.4$ & Kuch et al. (2001) \\
\hline
\end{tabular}

${ }^{\mathrm{a}}$ Based on average values

2005; Brändli 2006; Marb et al. 2003). A broadly based study of biocompost, green waste compost and digestates in Baden-Wuerttemberg showed comparable median concentrations of $13 \mathrm{ng} \mathrm{g}^{-1} \mathrm{DM}$, $5.4 \mathrm{ng} \mathrm{g}^{-1} \mathrm{DM}$, and $13.7 \mathrm{ng} \mathrm{g}^{-1} \mathrm{DM}$ and confirmed the low relevance of both materials as PBDE source (Kuch et al. 2007).

\subsection{Soil humidity}

Due to the lipophilic character of PBDEs, soil moisture also plays an important role in the plant uptake or atmospheric losses of PBDEs. High soil moisture effectively prevents evaporation of BDEs as well as plant uptake (Wu et al. 2018a). Correspondingly, a longer PBDE load may be expected at wet locations.

\subsection{Plastic particles}

The partition coefficients of PBDEs towards various plastics are several orders of magnitude higher than those towards sewage sludge or soil (Teuten et al. 2007). Therefore, the hypothetical potential of soil remediation by injection of plastic particles was positively investigated. Due to the lack in biodegradability and spread of microplastics, however, this approach is not applicable.

\subsection{Other additives}

Additional additives like graphene, $\mathrm{TiO}_{2}, \mathrm{Al}_{2} \mathrm{O}_{3}, \mathrm{Ag}$, and carbon nanotubes were considered as relevant for BDE-209 uptake in spinach, pumpkin, cucumber, corn and water spinach by Wu et al. (2018b). Indeed, an increased plant uptake was observed for all of these additives. Despite the desorbing effect of these additives in soil, the bioavailability of BDE-209 in aqueous phase was between 0.3 and $0.5 \%$ of the initial concentration, i.e. $99.5-99.7 \%$ of the BDE concentration remained adsorbed to the soil matrix or external plant tissues.

Uptake of BDE-153 by lettuce in presence of the borosilicate mineral tourmaline and soluble humic acids was tested by Wang et al. (2017). In both cases an increased accumulation in both roots and shoots was observed. Whether this effect also occurs in other crops is still unclear. In case of the humic acids, a weak surfactant effect was expected due to their structure. A combination of bentonite and sodium persulfate as oxidizing agent was tested regarding to the bioavailability and eliminability of a mixture of 10 PBDEs $\left(\mathrm{Br}_{3}-\mathrm{Br}_{10}\right)$ in soil. While bentonite proved to be particularly positive in immobilization of heavy metals as co-contamination, sodium persulphate enhanced bioavailability of PBDEs by in-situ oxidation. Negatively, bacterial density was sharply reduced with a recovery over 90 days (Ma et al. 2020). 

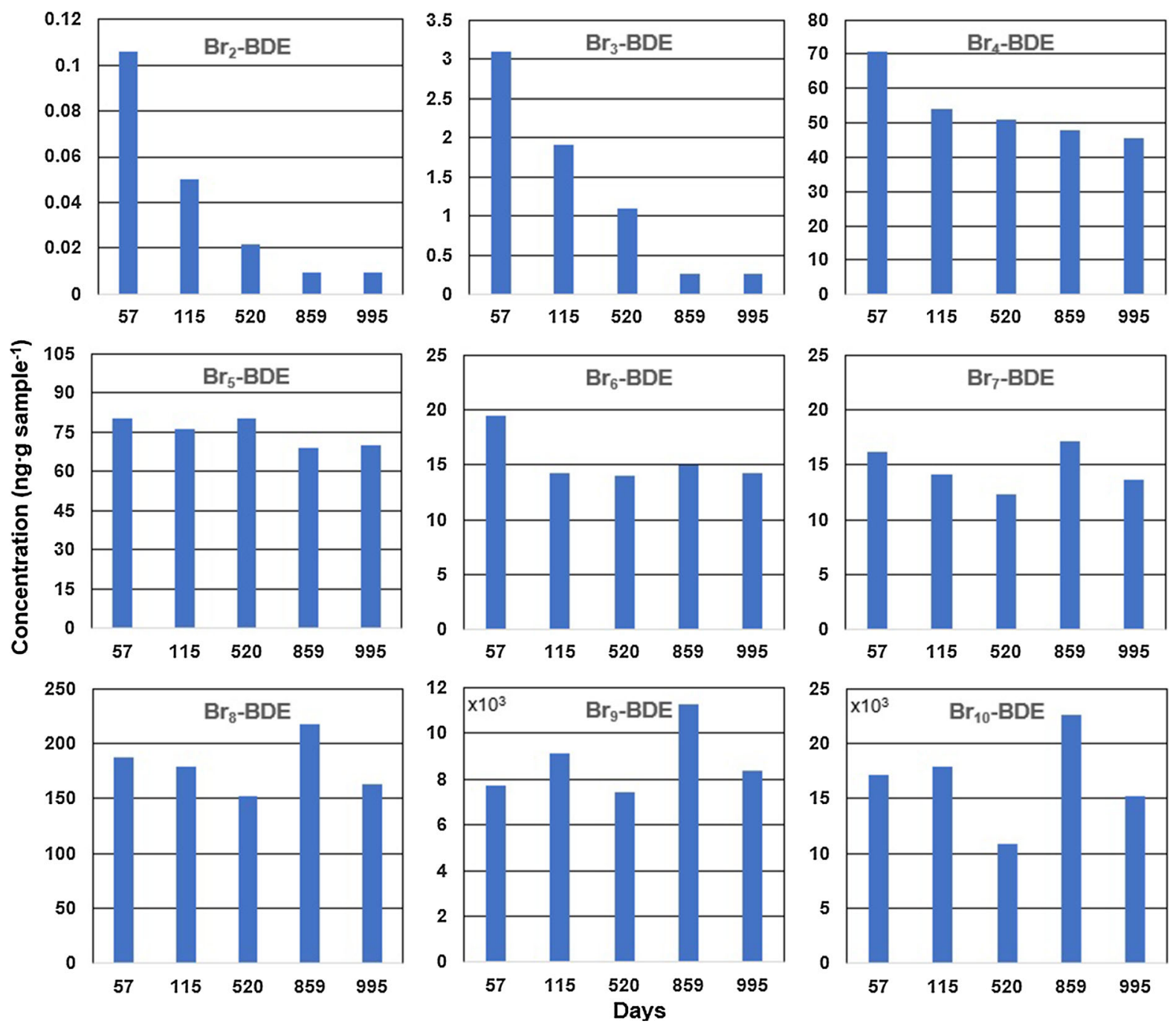

Fig. 2 Concentration of BDEs in sewage sludge/soil mixtures over 3 years after fertilization measure (based on Venkatesan and Halden 2014; simplified)

\subsection{Solubilizers}

The addition of surfactant-active additives leads to a reduction in the binding strength of highly halogenated PBDEs in particular to the soil matrix or the outer plant tissue, whereby both mobility of PBDEs in soil matrix and plant uptake are enhanced. While this is a desirable effect for phytoremediation, this approach is not applicable to plants for food production. For details on the use of solubilizers see Sect. 5.3 and Binelli et al. (2007).

\subsection{Macro- and trace elements}

Macro- und trace elements appear to be essential for the development of the microflora in the rhizosphere as well as for plant growth, but further differentiation is required in case of elimination and uptake of PBDEs.

In case of nitrate as additive an intensified desorption and biodegradation of BDE-99 was observed (Yan et al. 2017). Starting from an initial concentration of $770 \mathrm{ng} \mathrm{g} \mathrm{DM}^{-1}$ BDE-99, turnovers of BDE-99 and corresponding intermediates increased by $66 \%$ and $63 \%$ since nitrate appears to be an alternative electron acceptor increasing microbial turnover in the 
soil phase. Hence, a residual concentration of 310 instead of $710 \mathrm{ng} \mathrm{g} \mathrm{DM}^{-1}$ BDE-99 was determined.

In contrast to the expectation of a positive effect of an adequate trace element supply on microflora and microbial biodegradation behavior of PBDEs, Zhu et al. (2018) observed neither a positive nor a negative influence on PBDE uptake or PBDE degradation in plants affected by various macro- and trace elements ( $\mathrm{Si}, \mathrm{Ca}, \mathrm{Fe}, \mathrm{Al}, \mathrm{S}, \mathrm{K}, \mathrm{Ti}, \mathrm{P}, \mathrm{Mg}, \mathrm{Na}, \mathrm{Mn}, \mathrm{Zn}, \mathrm{Cl}, \mathrm{As}, \mathrm{Cu}$, $\mathrm{Cr}, \mathrm{Ni}$ ). As expected, microbial inhibition of BDE mineralization occurred at higher concentrations of trace elements, i.e.-30\% for BDE-3 at $400 \mathrm{mg} \mathrm{Cu} \mathrm{kg}$ $\mathrm{DM}^{-1}$ (Yao et al. 2020). For the sake of completeness, it should be noted that to date the potentially positive influence of trace elements on the microbial turnover of PBDEs was not addressed in a scientific study and therefore awaits final evaluation.

\subsection{Heavy metals}

In comparison to reference soil, Wu et al. (2018a) described a reduction in plant uptake of BDE-209 by almost $20 \%$ in pot cultures with Pak Choi plants (Brassica chinensis) in presence of $\mathrm{Ni} / \mathrm{Fe}$ nanoparticles, whereas the uptake of $\sum$ PBDEs increased by approx. $85 \%$ in the opposite direction. The iron content of the soil was increased from approx.

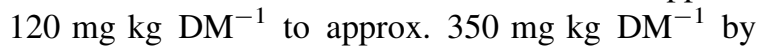
addition of these particles, while the nickel content was not quantified. The higher PBDE uptake was justified by chemical debromination of BDE-209 and enhanced mobilization, uptake and transport of $\mathrm{Br}_{8}$ - to $\mathrm{Br}_{10}$-BDEs in the roots and shoots of the plants. This changed uptake behavior was also reflected in a higher translocation factor of 4.2 compared to $<0.02$ for $\mathrm{Br}_{8}$ BDEs. This result should be critically appraised due to a drop of translocation factors of $\mathrm{Br}_{9}$-BDEs, BDE-209 and $\sum$ PBDE by $60 \%, 45 \%$ and $75 \%$, respectively. In contrast, BDE-47 plant uptake was positively influenced by iron addition as described by Pi et al. (plant uptake: $24.76 \%$ instead of less than $1.5 \%$ ) (Pi et al. 2017).

Unlike the addition of iron, Lu et al. (2013) observed a reduction of BDE-209 uptake up to $50 \%$ by pumpkins ( $1180 \mathrm{ng} \mathrm{g} \mathrm{DM}^{-1}$ vs. $2370 \mathrm{ng} \mathrm{g} \mathrm{DM}^{-1}$ in roots) after addition of $300 \mathrm{mg} \mathrm{Cu} \mathrm{kg} \mathrm{DM}^{-1}$ to the soil. At further increasing levels inhibitory effects on microbial mineralization of PBDEs in soil were observed (Yao et al. 2020). At levels up to $1950 \mathrm{mg}$
$\mathrm{Pb} \mathrm{kg} \mathrm{DM}{ }^{-1}$ plant uptake of BDE-209 was reduced by a factor of 2.9-3.7 by tall fescue (Festuca arundinaceae; Chen et al. 2019). While no effect on BDE209 uptake was observed for black nightshade at cadmium levels up to $14,800 \mathrm{ng} \mathrm{g} \mathrm{DM}^{-1}$ ( $\mathrm{Li}$ et al. 2018b), enhanced BDE-209 uptake was shown for amaranth (Amaranthus hypochondriacus L.; Li et al. 2020a).

In summary, a positive effect seems to result from the presence of essential heavy metals such as iron and copper at adequate concentrations, while non-essential heavy metals at non-toxic levels seem to have no effect on PBDE degradation. A direct effect on PBDE uptake into the plant is also not expected due to the ionic character of the heavy metals as opposed to the highly lipophilic PBDEs.

\section{Predictive mathematical models}

Due to the broad spectrum of plants used for food production, phytoremediation and eco-indication, efforts are being made to develop sensitive predictive models based on simple chemical conditions and input variables in order to be able to determine the exposure of potential food plants in advance. These mathematical models require input parameters like distribution equilibria, fat content, organic matter and soil-water concentration, PBDE concentration to varying degrees for a predictive statement about the RCF value, SCF value (shoot concentration factor) or the TF value.

Exemplarily, the model of Li et al. (2019b) allows a prediction of the RCF and the SCF based on the input parameter $\log \mathrm{K}_{\mathrm{OW}}$ and lipid content. The derived linear equation defined for the RCF value enable a good correlation between the modelled and the detected values, but did not differentiate intrinsic against externally adsorbed PBDE. Moreover, the model strongly failed in prediction of the SCF values that deviate by up to 2 decades from the real situation. A similar range was also reported by Collins et al. (2010). Even though dealing with the insecticide chlorpyrifos, the model of Hwang et al. (2017) showed a deviation of $25.3-58.2 \%$ for chlorpyrifos in case of lettuce, although the model is greatly simplified by the choice of the plant, as there is no need to differentiate between TF and SCR values.

Briggs et al. (1982) showed a significant decrease in BCF levels and thus RCF values of PBDEs starting at a 
$\log \mathrm{K}_{\mathrm{OW}}$ value of approx. 6.5 (corresponds to a $\log$ BCF value of approx. 4.6 or a molar mass of approx. 500-600 Da) after elimination of externally adsorbed congeners (see Fig. 3). This chart corresponds to Bintein's bilinear model (Bintein et al. 1993), which was confirmed by Meylan et al. (1999) for 610 nonionic pollutants. This negative correlation at high log $\mathrm{K}_{\mathrm{OW}}$ values and thus high lipophilicity bases on three restrictions of lipophilic compounds as follows:

1. Kinetic of the state of equilibrium The higher the lipophilicity of a pollutant, the longer it takes to achieve the state of equilibrium between two phases or compartments. The life span of annual crops might be too short to establish an equilibrium between soil and root or root and shoot (Nendza 1991).

2. Solubility Water solubility decreases by increasing lipophilicity and highly lipophilic substances preferentially adsorb on particles or surfaces. For absorptive root uptake of contaminants, however, both phase transition from soil to liquid phase and from liquid to intrinsic roots without adsorptive elimination on the tissue is required (Briggs et al. 1982; Nendza 1991).

3. Membrane permeability and cellular transport mechanisms The cellular uptake of pollutants through the cell membrane takes place by passive permeation (Briggs et al. 1982). The membrane

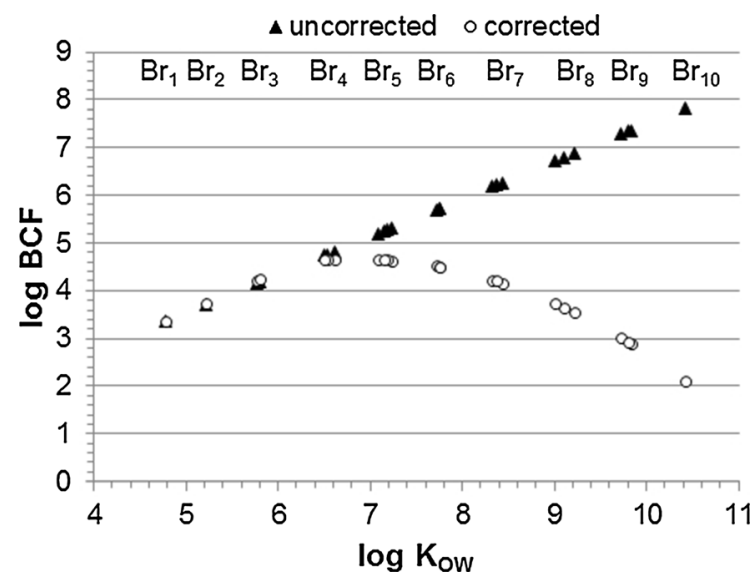

Fig. 3 Correlation of $\log \mathrm{K}_{\mathrm{OW}}$ and $\log \mathrm{BCF}$ of 25 environmental relevant BDEs $(-3,-7,-17,-28,-30,-47$, $-49,-66,-85,-99,-100,-123,-153,-154,-155$, $-183,-184,-191,-197,-201,-202,-206,-207$, - 208, - 209) using simple mathematical models with/without correction permeability and thus bioavailability of contaminants is concisely described by Lipinski's 'Law of $5^{\text {, }}$, stating out low absorption or membrane permeability at:

(a) $\log \mathrm{K}_{\mathrm{OW}}$ value $>5$

(b) molar mass $>500$

(c) more than 5 hydrogen bond donors (well represented by the sum of $\mathrm{OH}$ and $\mathrm{NH}$ bonds)

(d) more than $10(=2 \cdot 5)$ hydrogen bond acceptors (simplified assumed by the sum of Ns and Os in the molecule).

In fact, requirements (a) and (b) are fulfilled in case of the PBDE correlation, where (b) is already met in case of $\mathrm{Br}_{4}$ - to $\mathrm{Br}_{5}$-BDEs. However, Yan et al. points out that permeability of contaminants might be affected by co-transport phenomena of biomolecules like amino acids (Yang and Hinner 2015).

Taking plant-specific uptake characteristics of individual BDEs into account, critical analysis of the data of Sect. 8 reveals maximum RCF values for technical and economical relevant BDE-47 and BDE99, but RCF values drop again at higher molar masses. In contrast, RCF levels of the isomer BDE-100 are consistently 2-40 times lower than those of BDE-99, which could be explained by a slightly lower $\log \mathrm{K}_{\mathrm{OW}}$ value of BDE-100 (7.08 vs. 7.18). The generally higher contamination of plants by BDE-209 than by the two former BDE congeners is caused by up to two decades higher soil contamination levels of BDE-209.

A critical evaluation of the literature data of Sect. 8, taking into account plant-specific uptake characteristics for individual BDEs, shows that a maximum RCF value actually occurs for the comparatively frequently analysed BDE-47 and BDE-99, which drops again at higher molar masses. In contrast, RCF values for the congener BDE-100 are consistently 2-40 times lower than those for BDE-99 despite the same molar mass, which can be explained by a slightly lower log KOW value (7.08 vs. 7.18). The generally higher exposure of plants to BDE-209 in absolute concentrations than to the two BDE congeners formerly mentioned is due to the up to 2 decades higher soil contamination with BDE-209.

A comparable correlation between $\log \mathrm{K}_{\mathrm{OW}}$ and $\mathrm{TF}$ value was observed for the comparatively polar pollutant classes of $O$-methylcarbamoyloximes and 


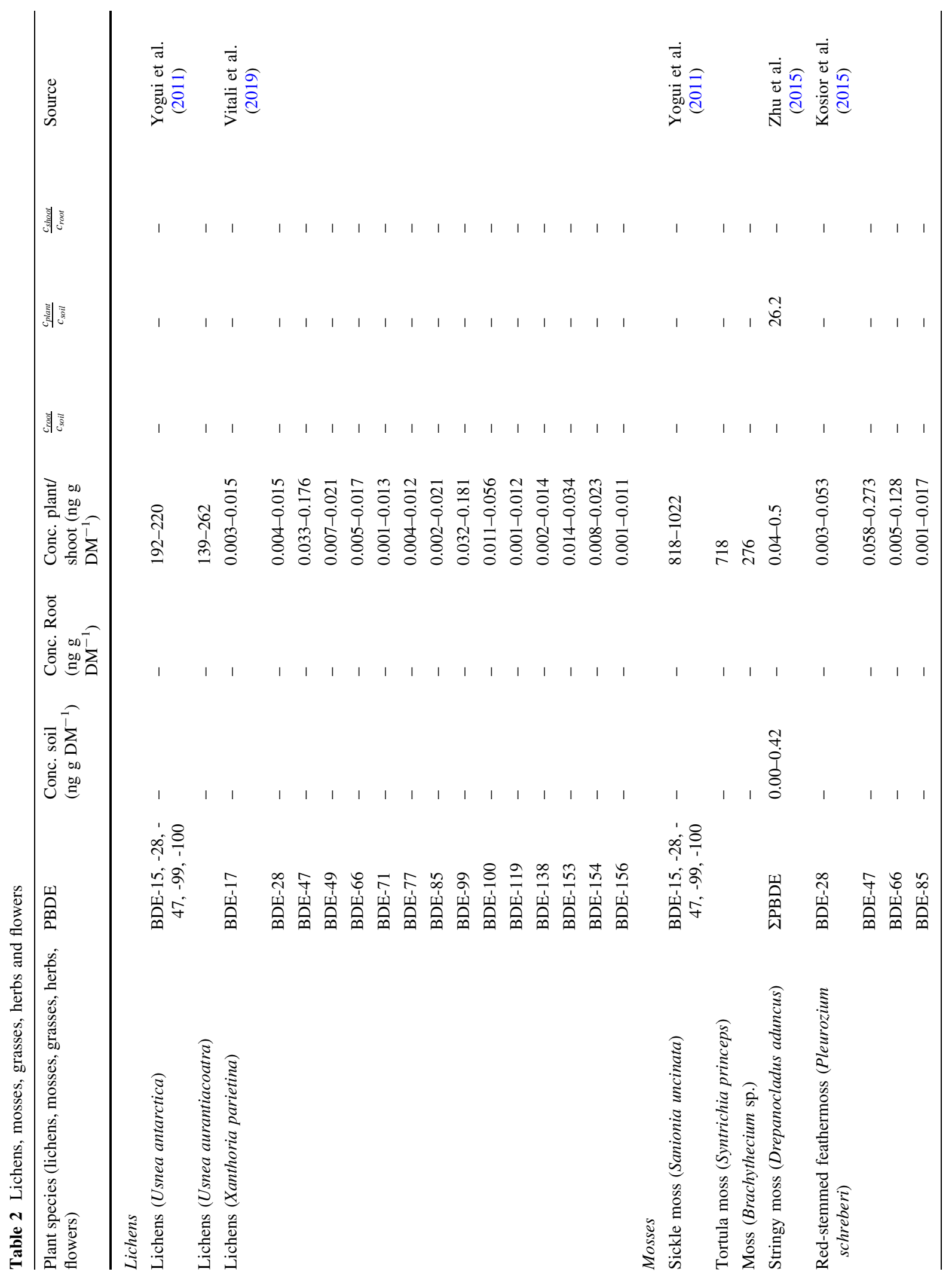




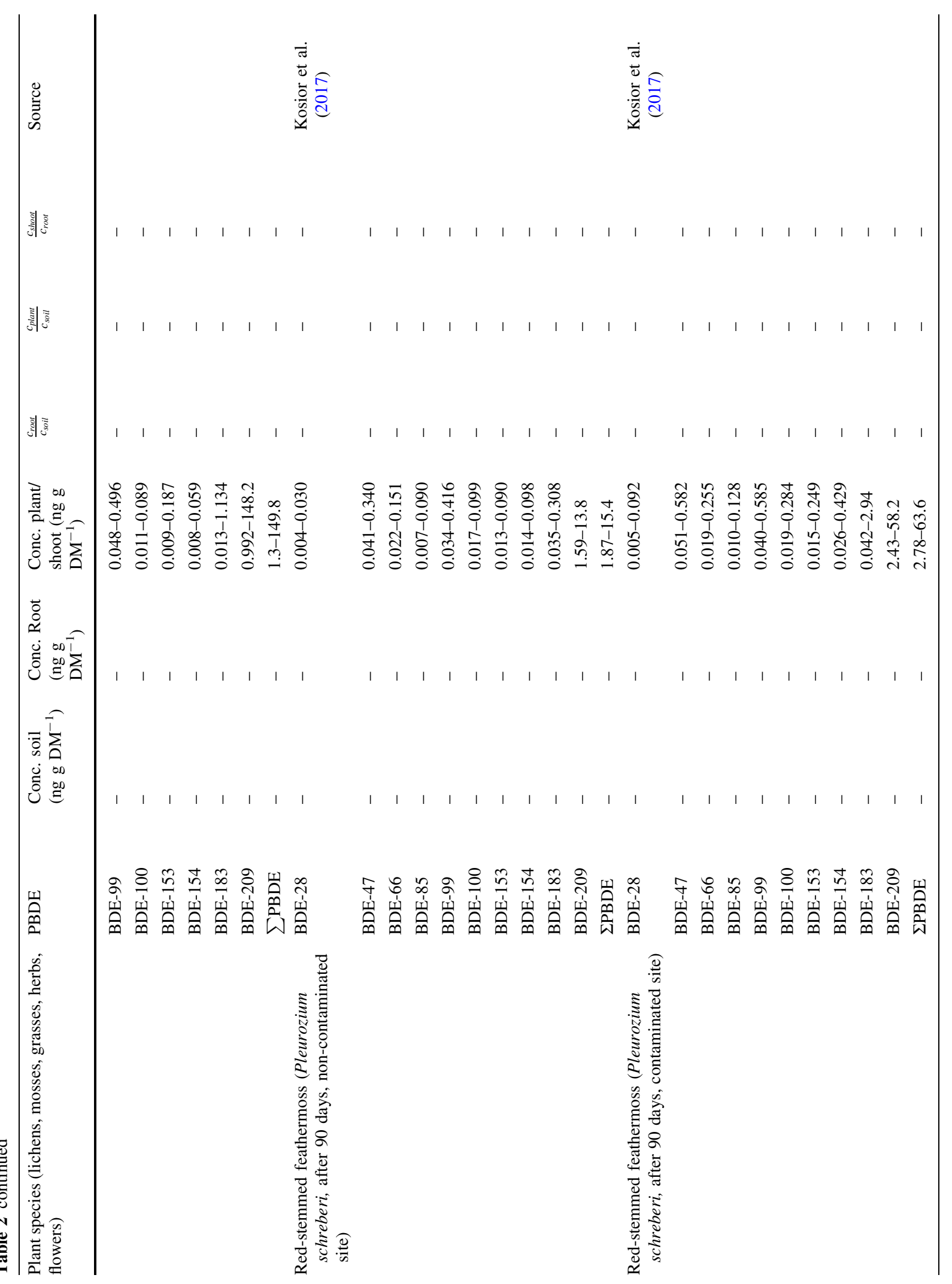




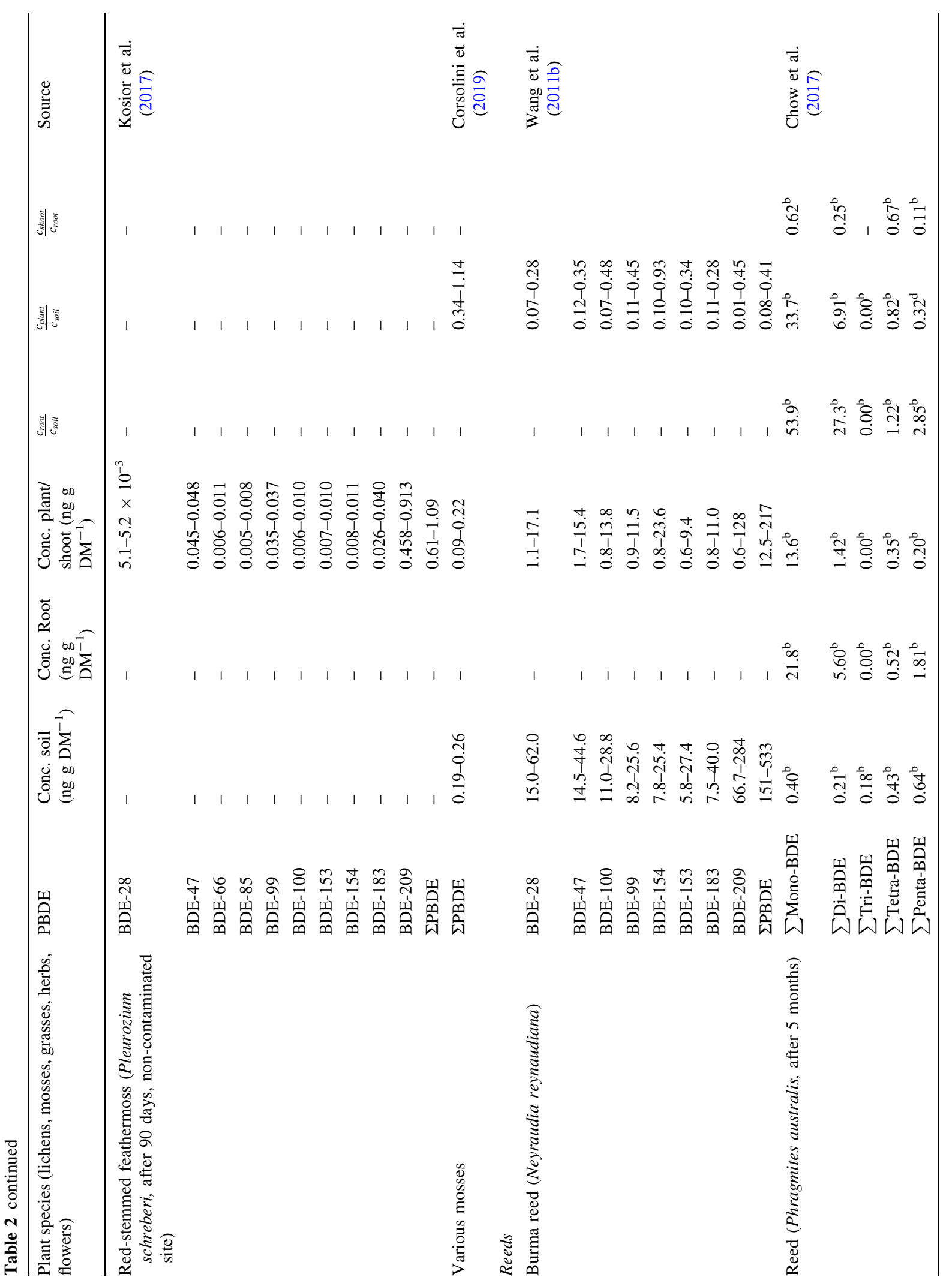




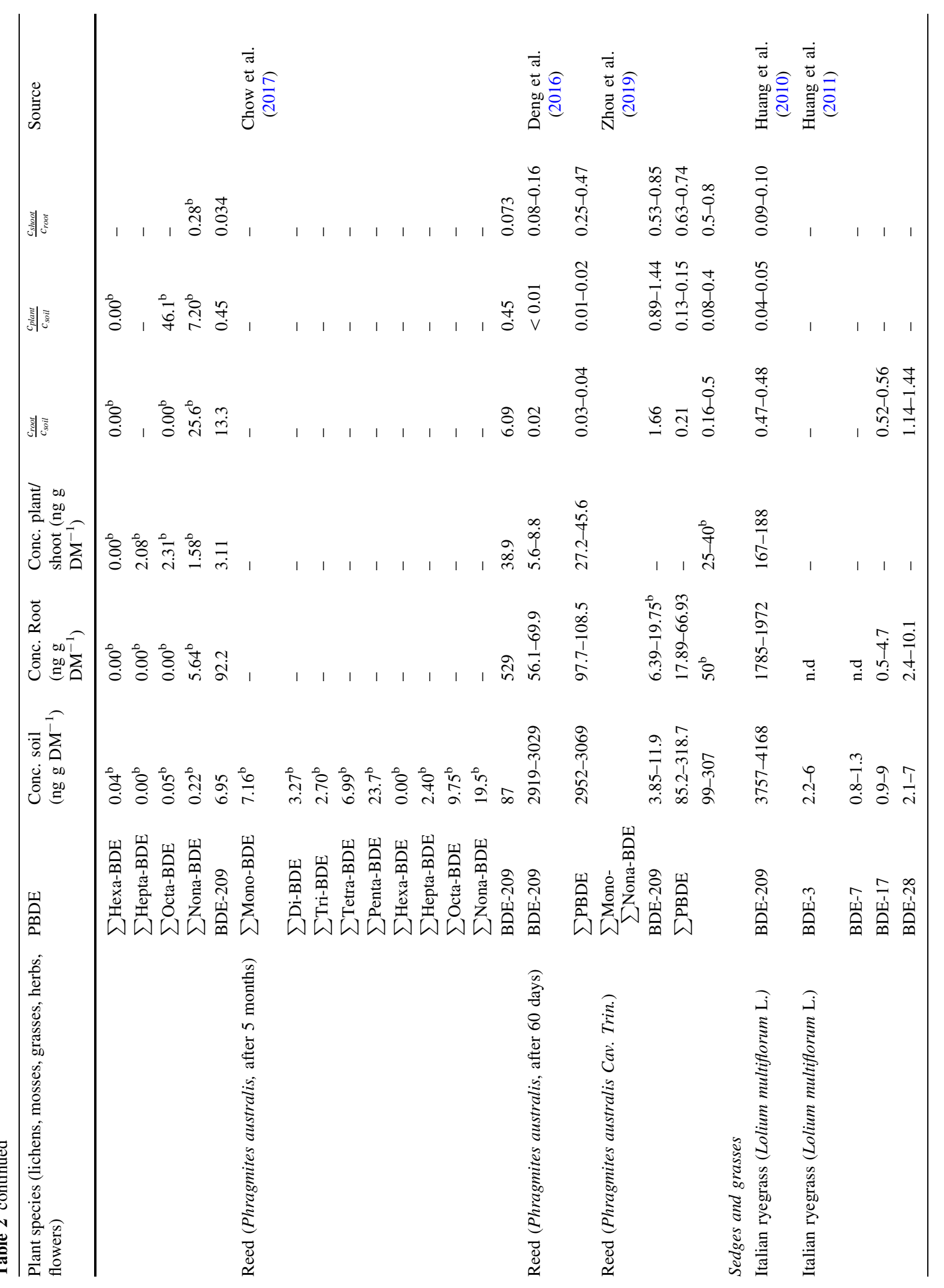




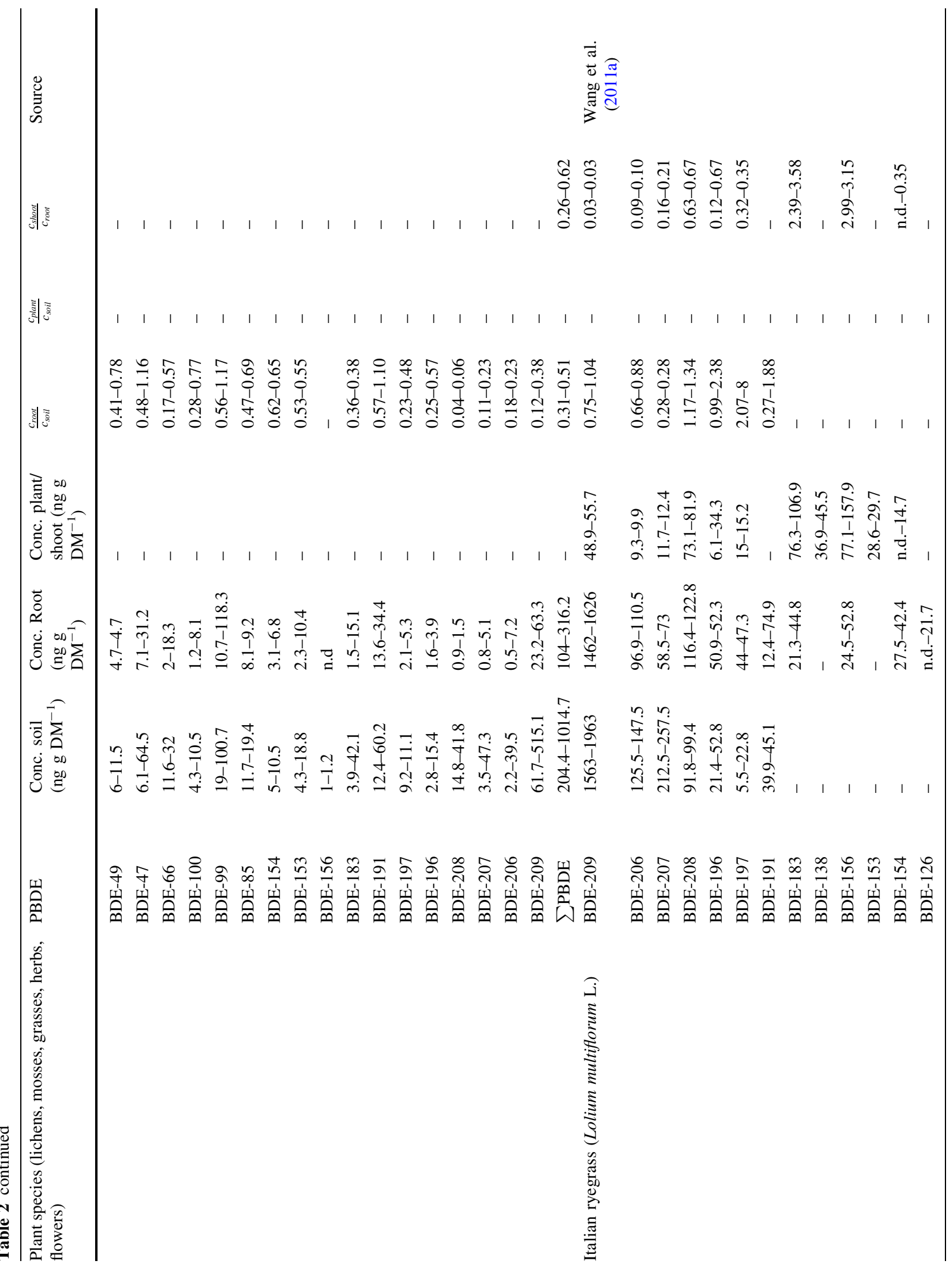




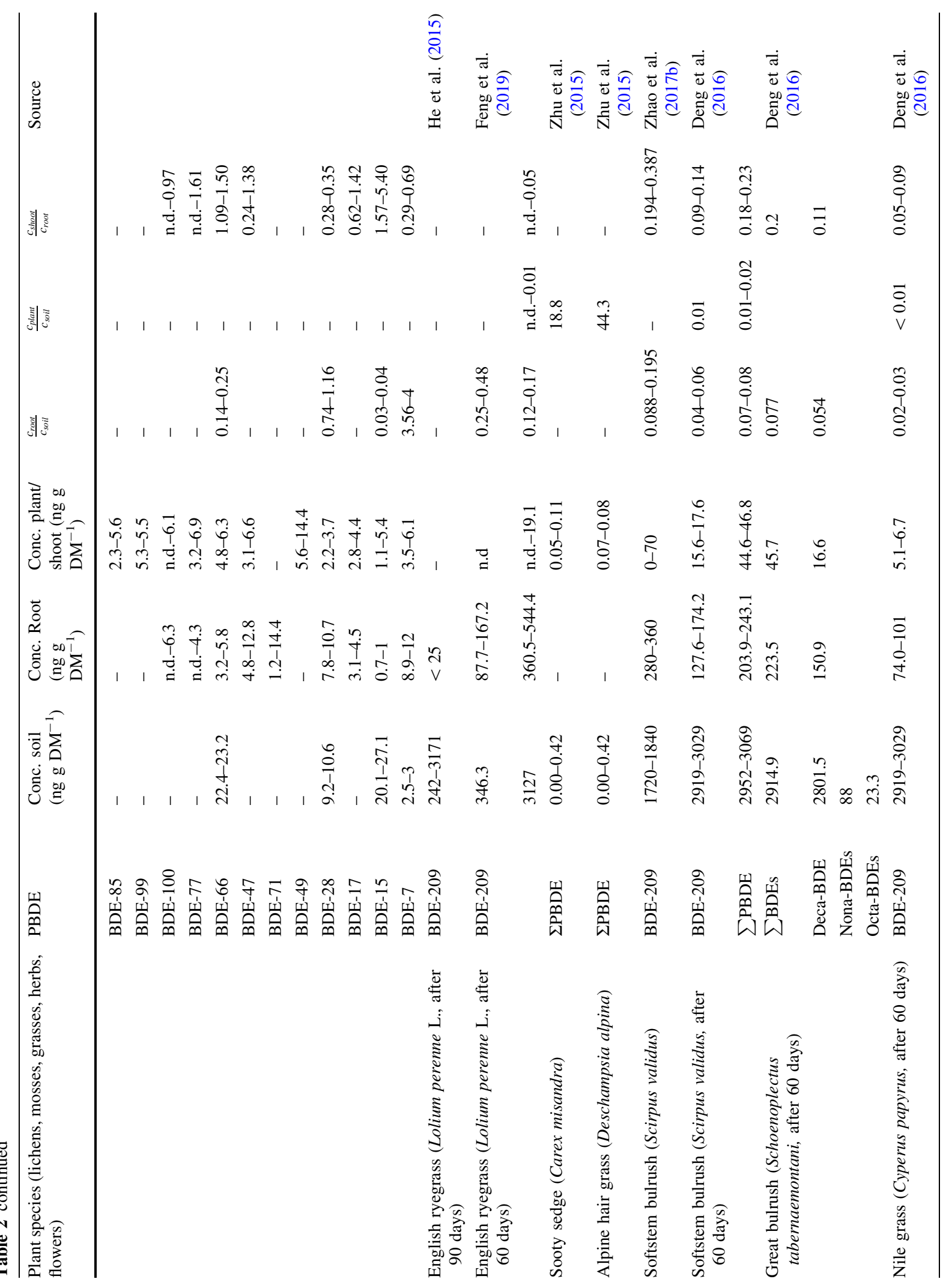




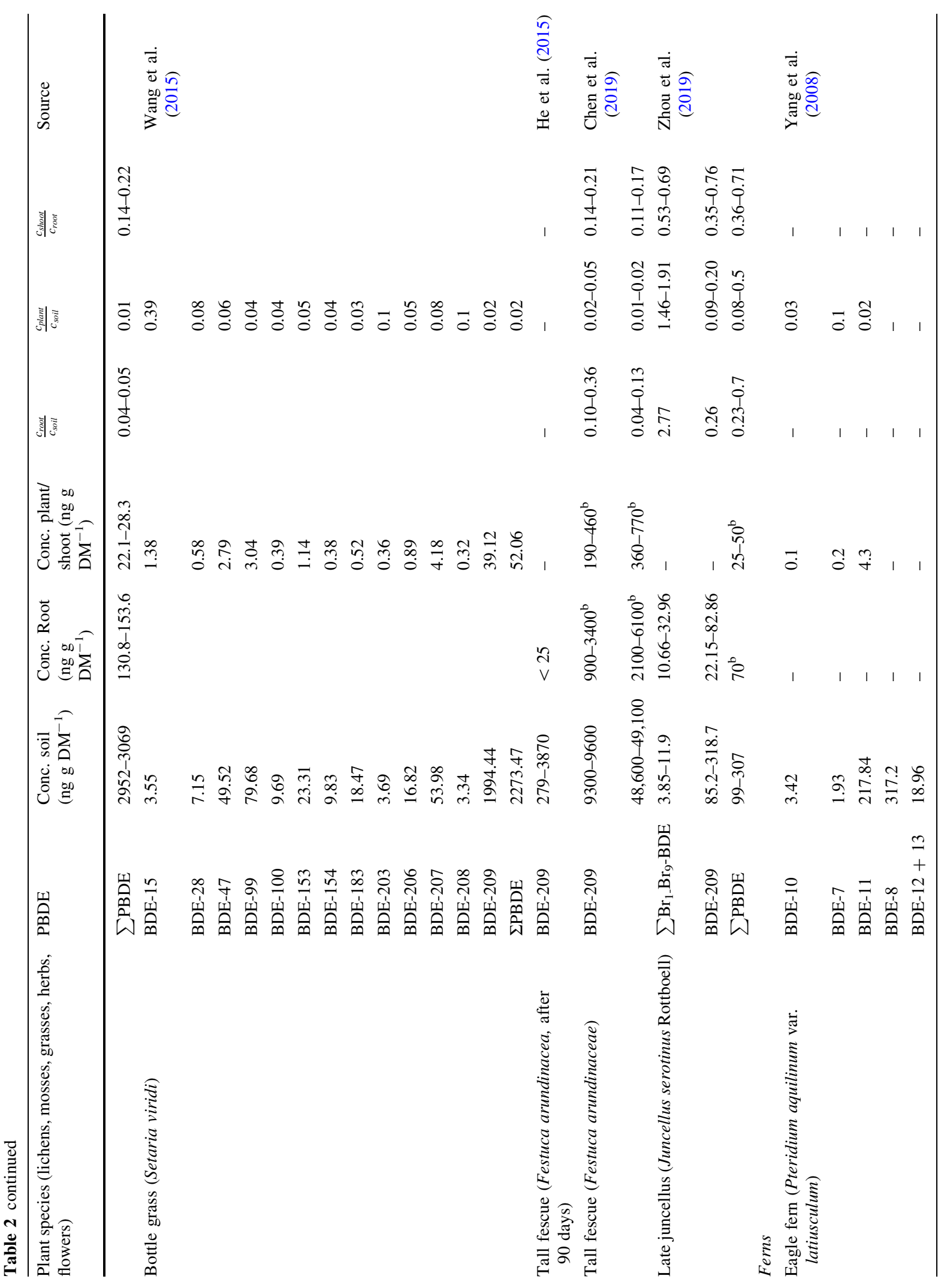




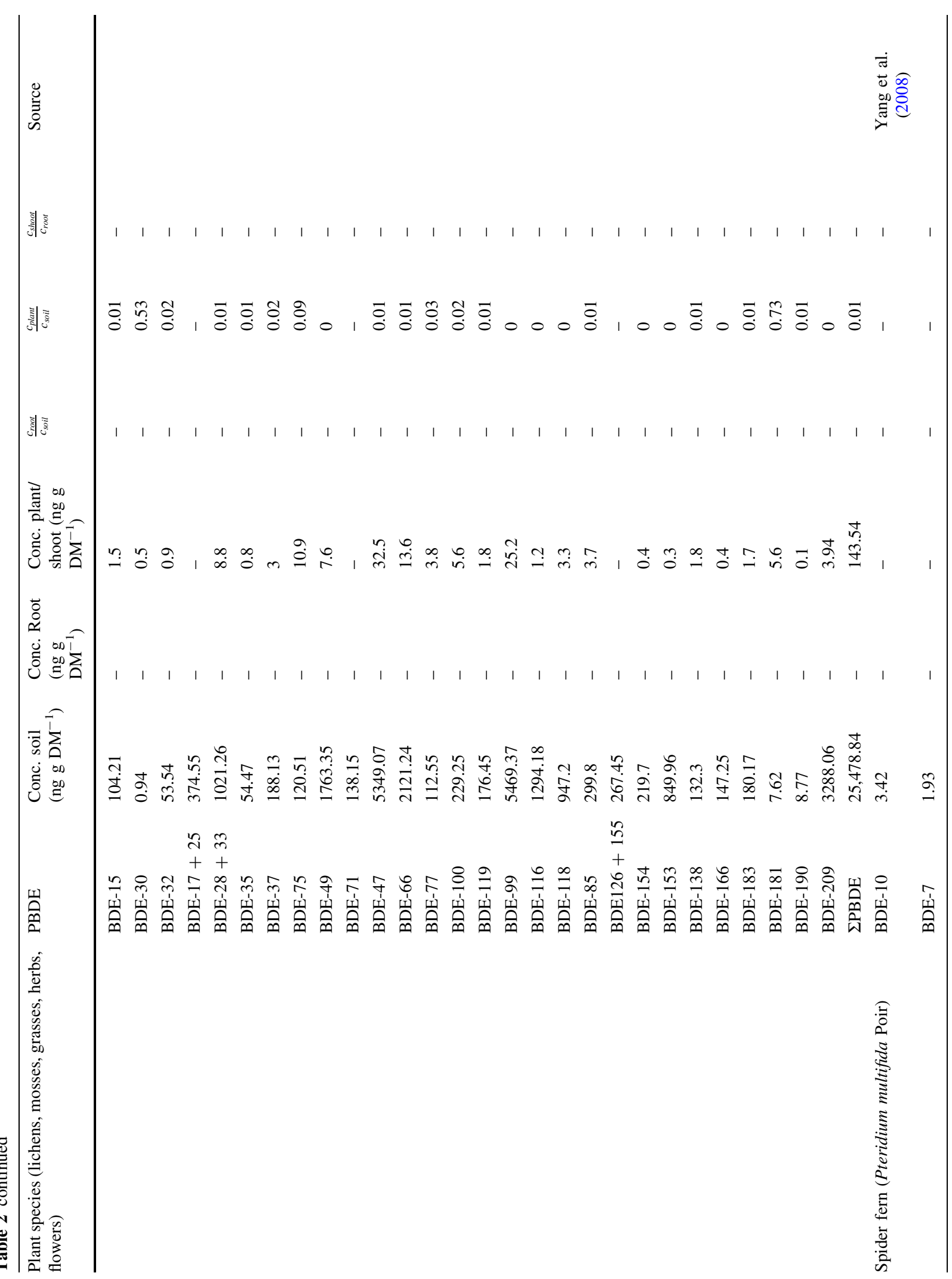




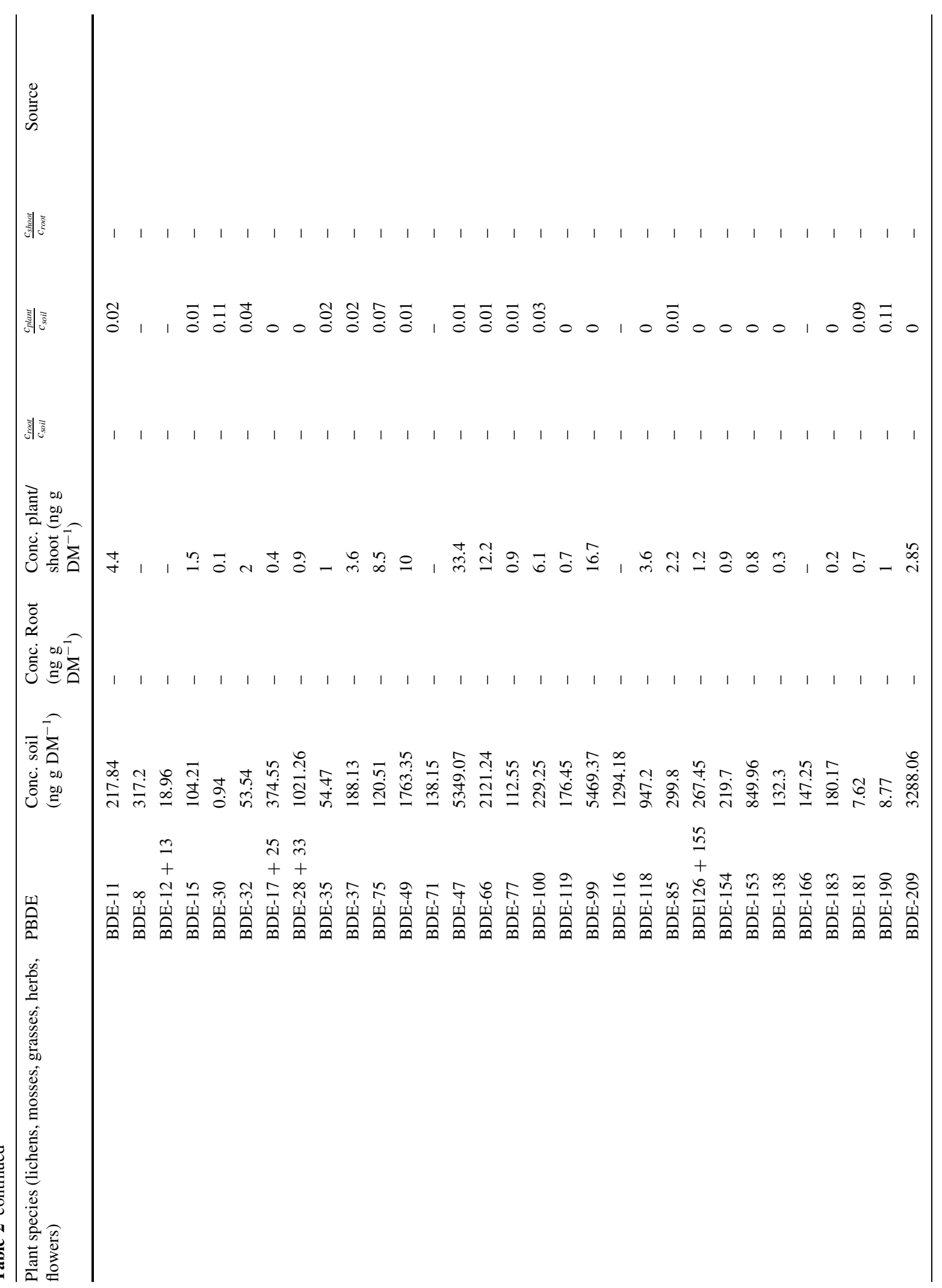




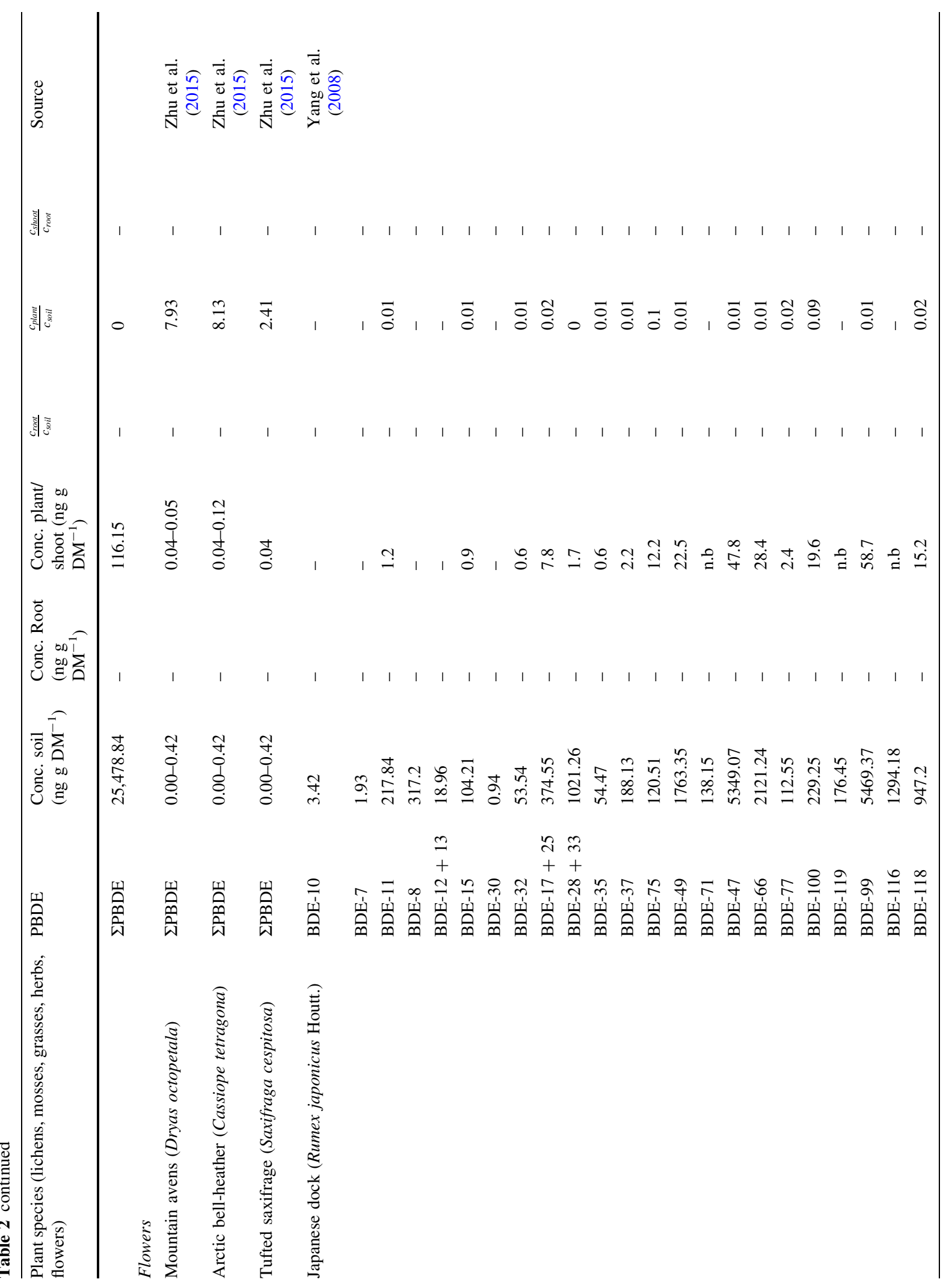




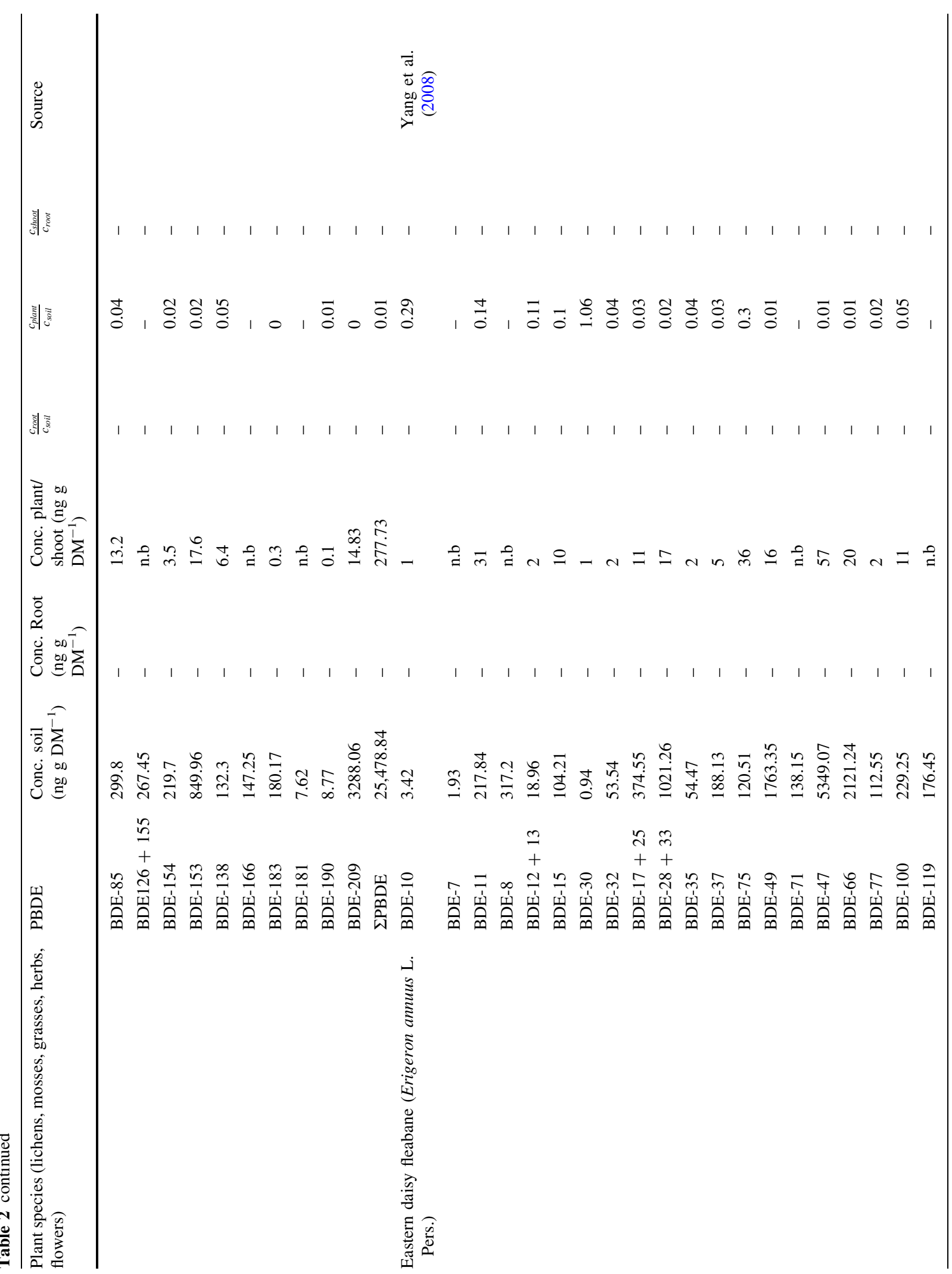




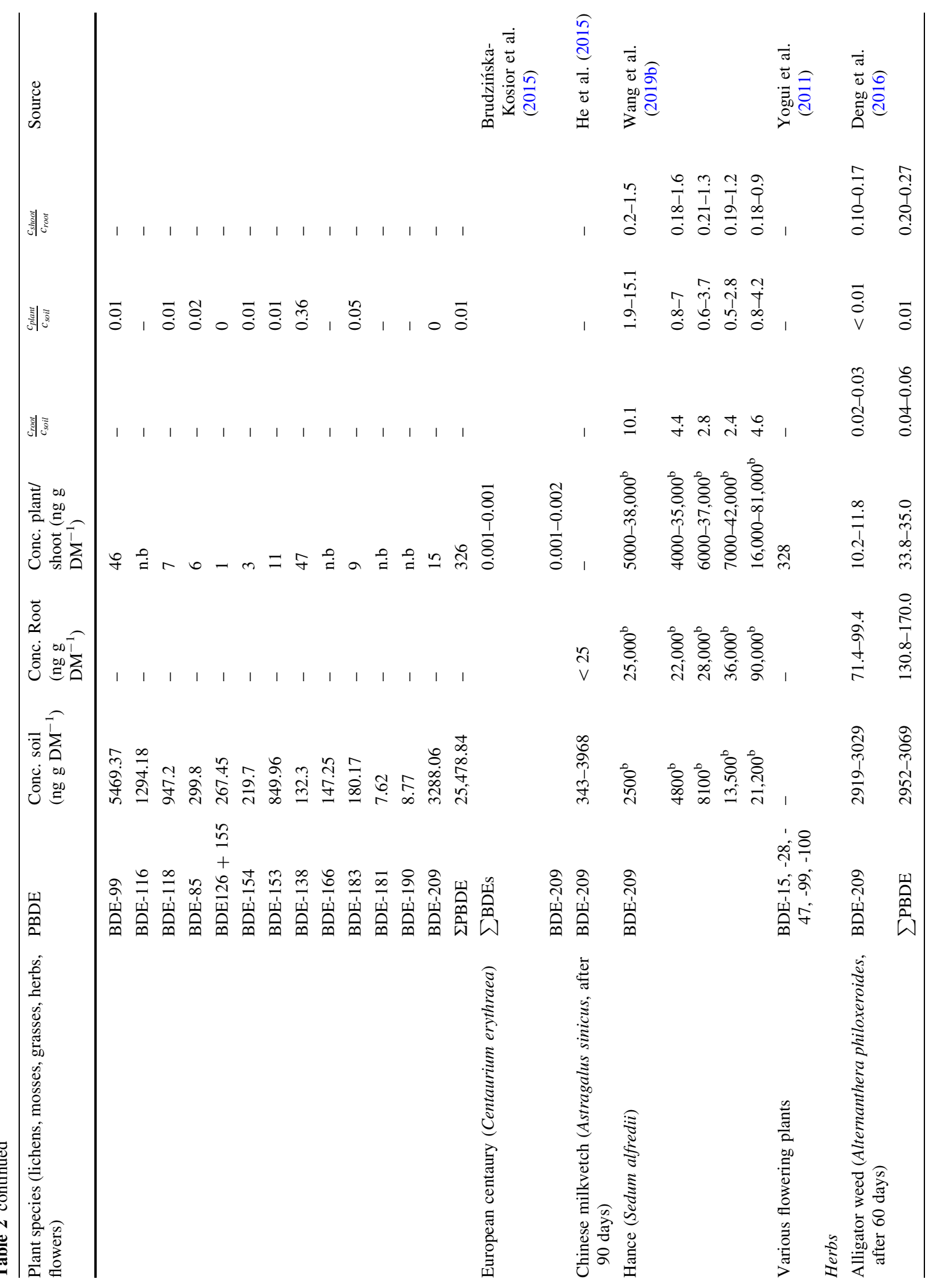




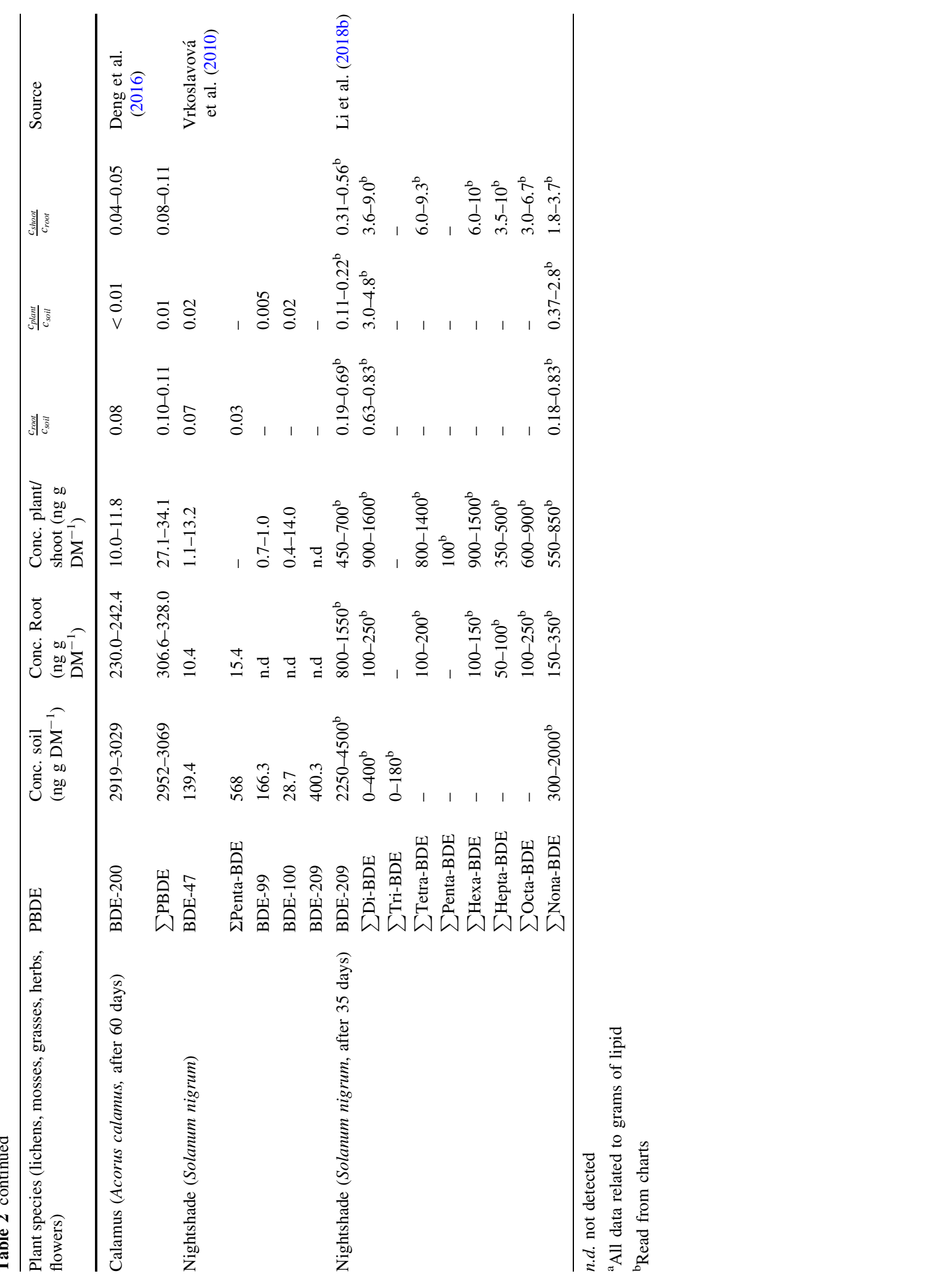




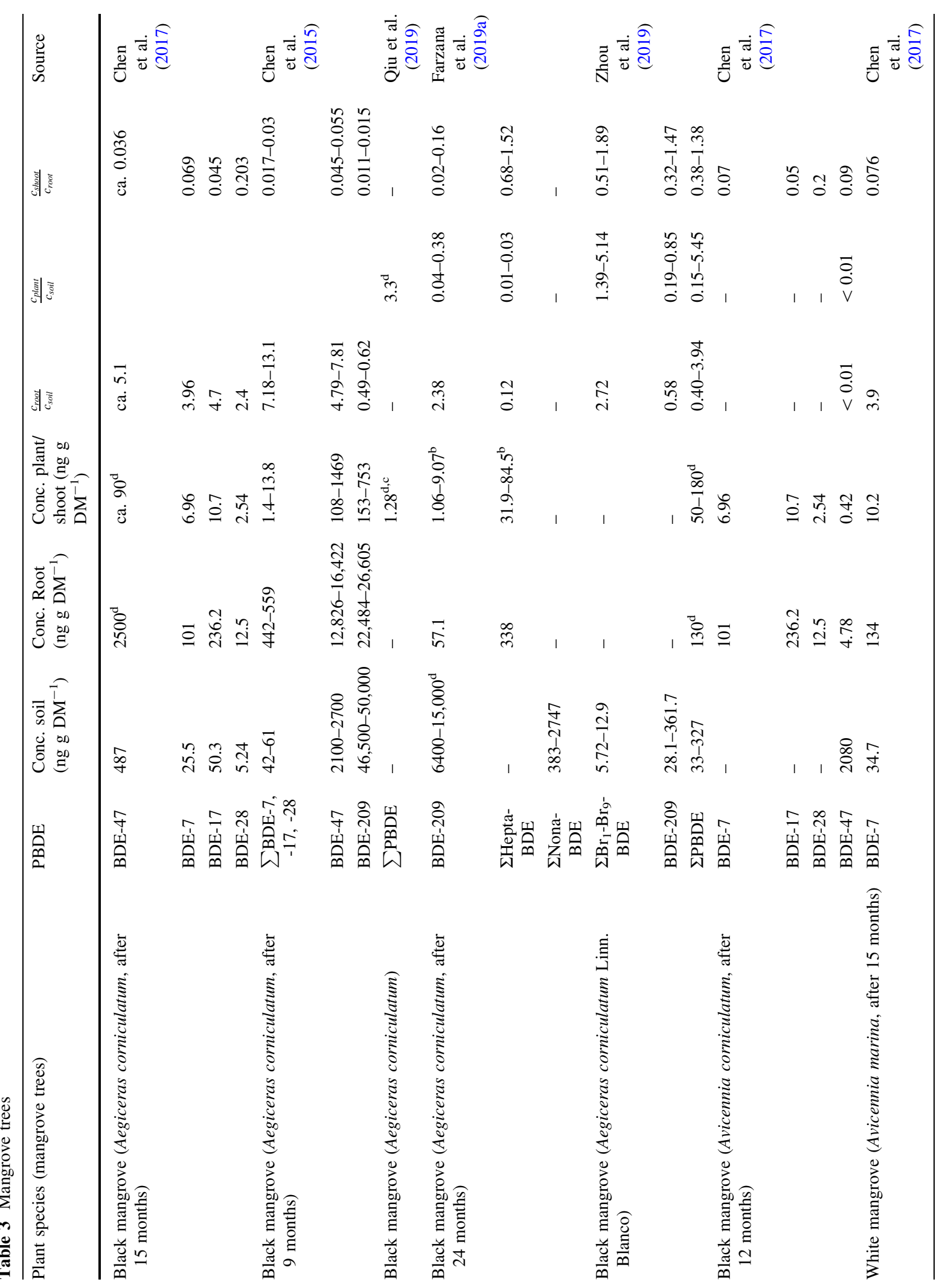




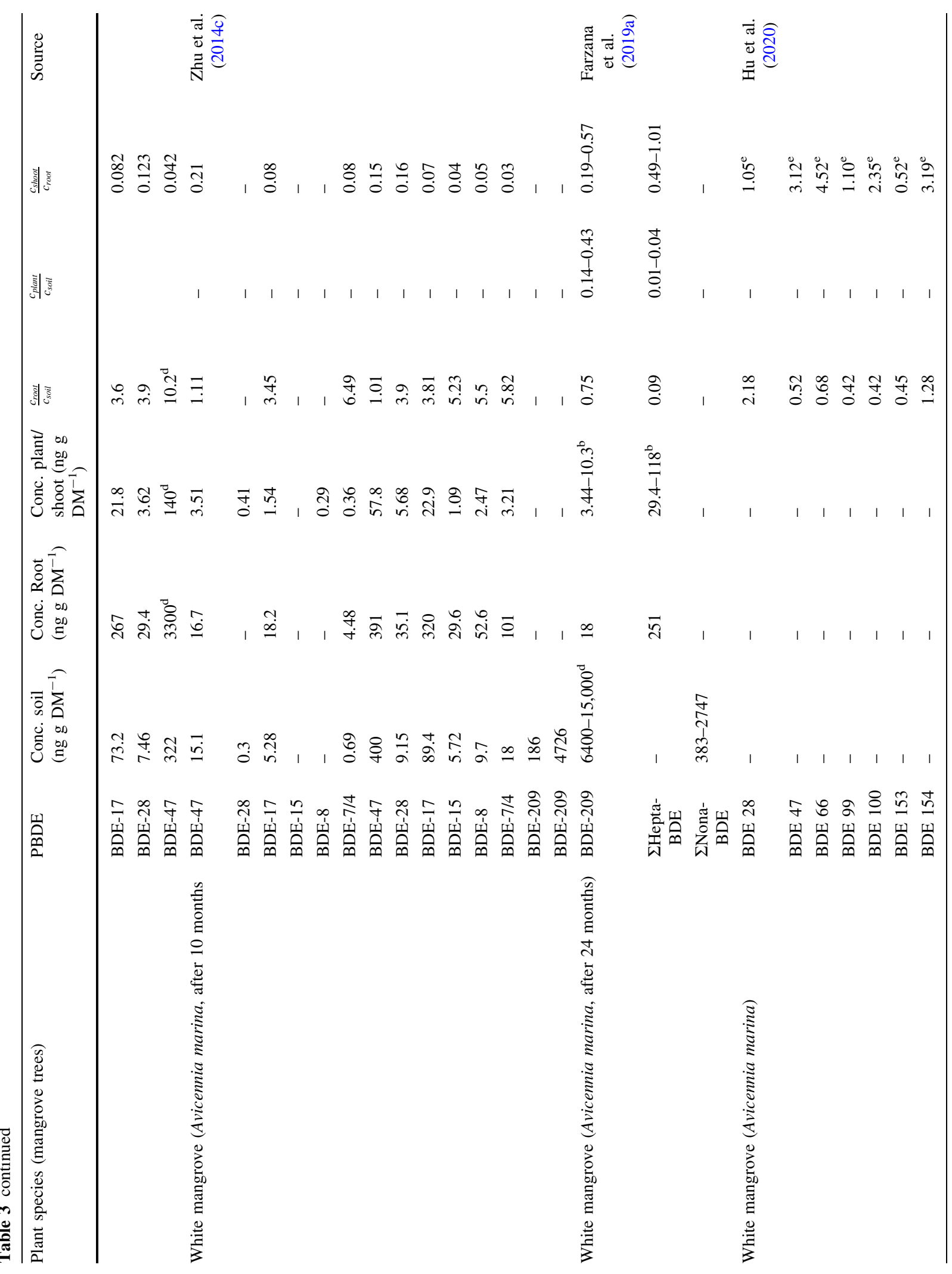




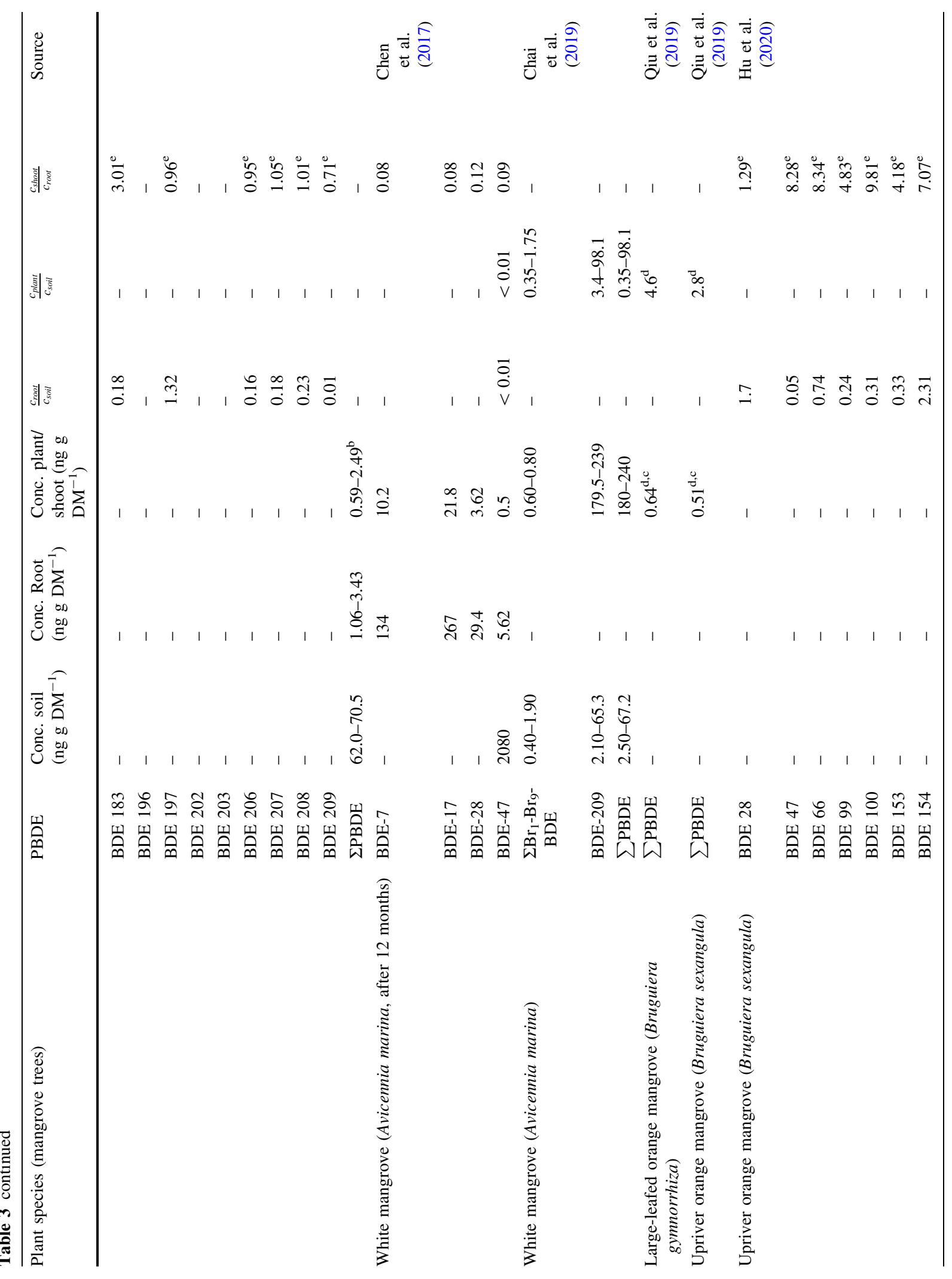




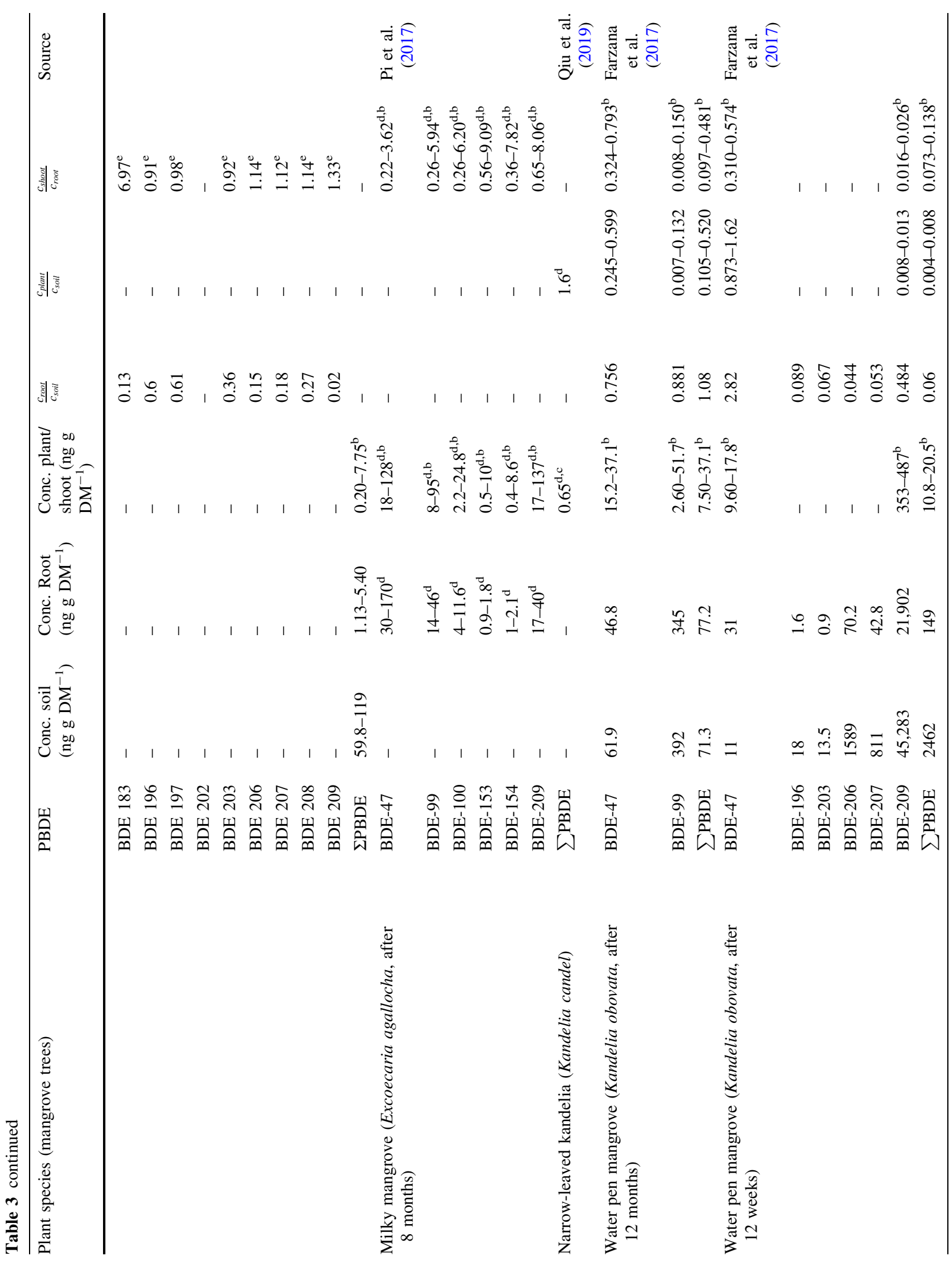




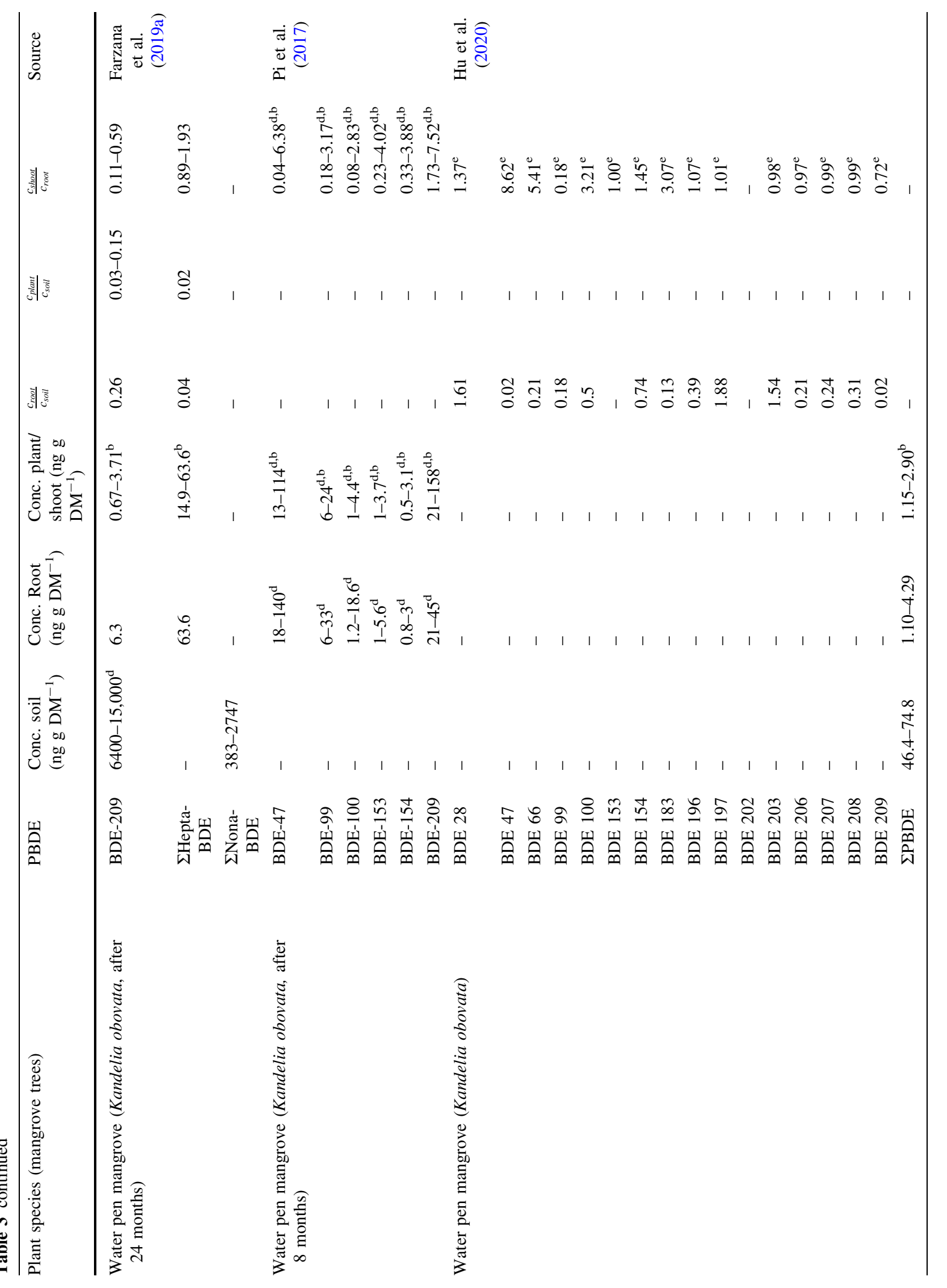




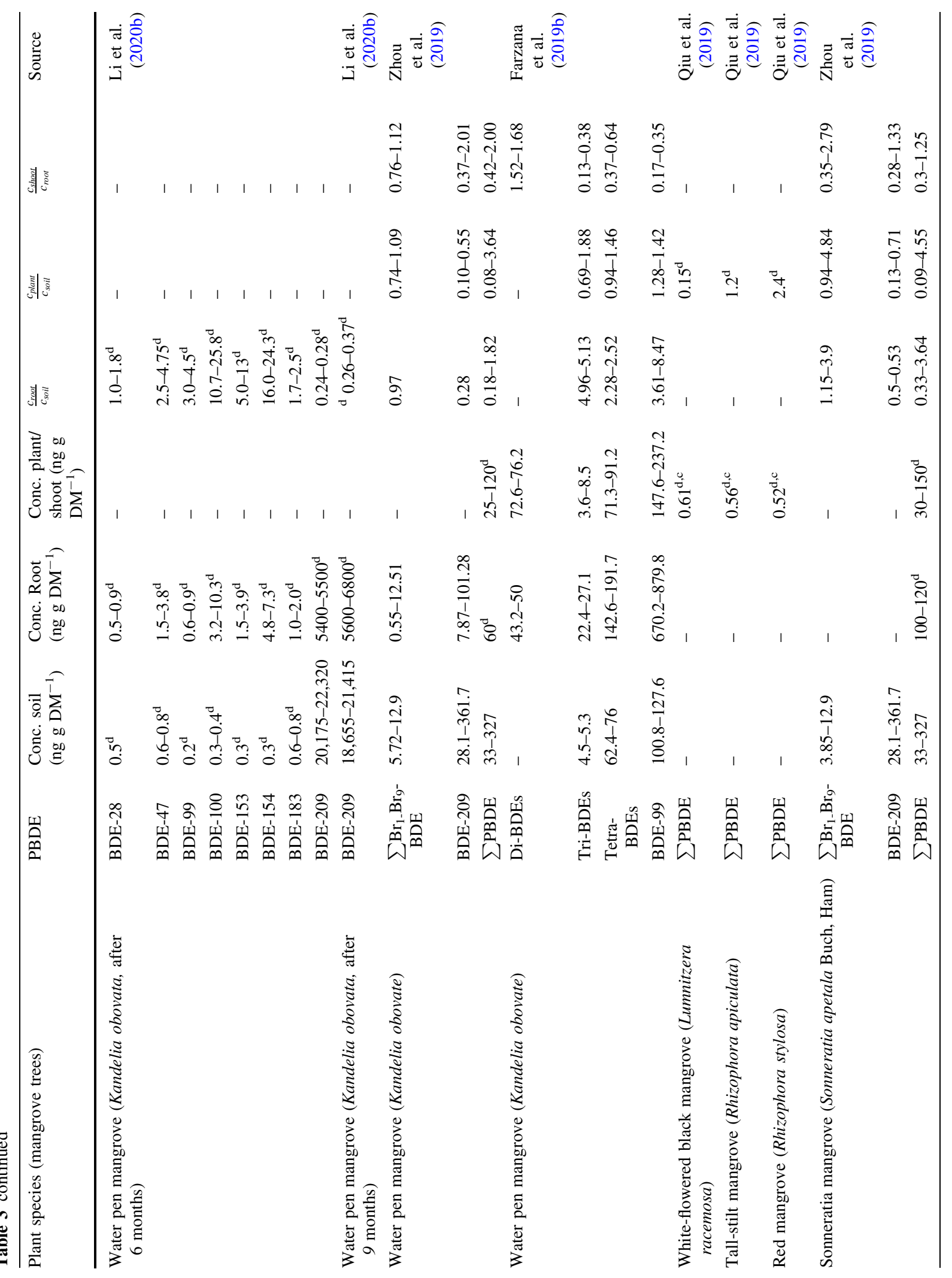




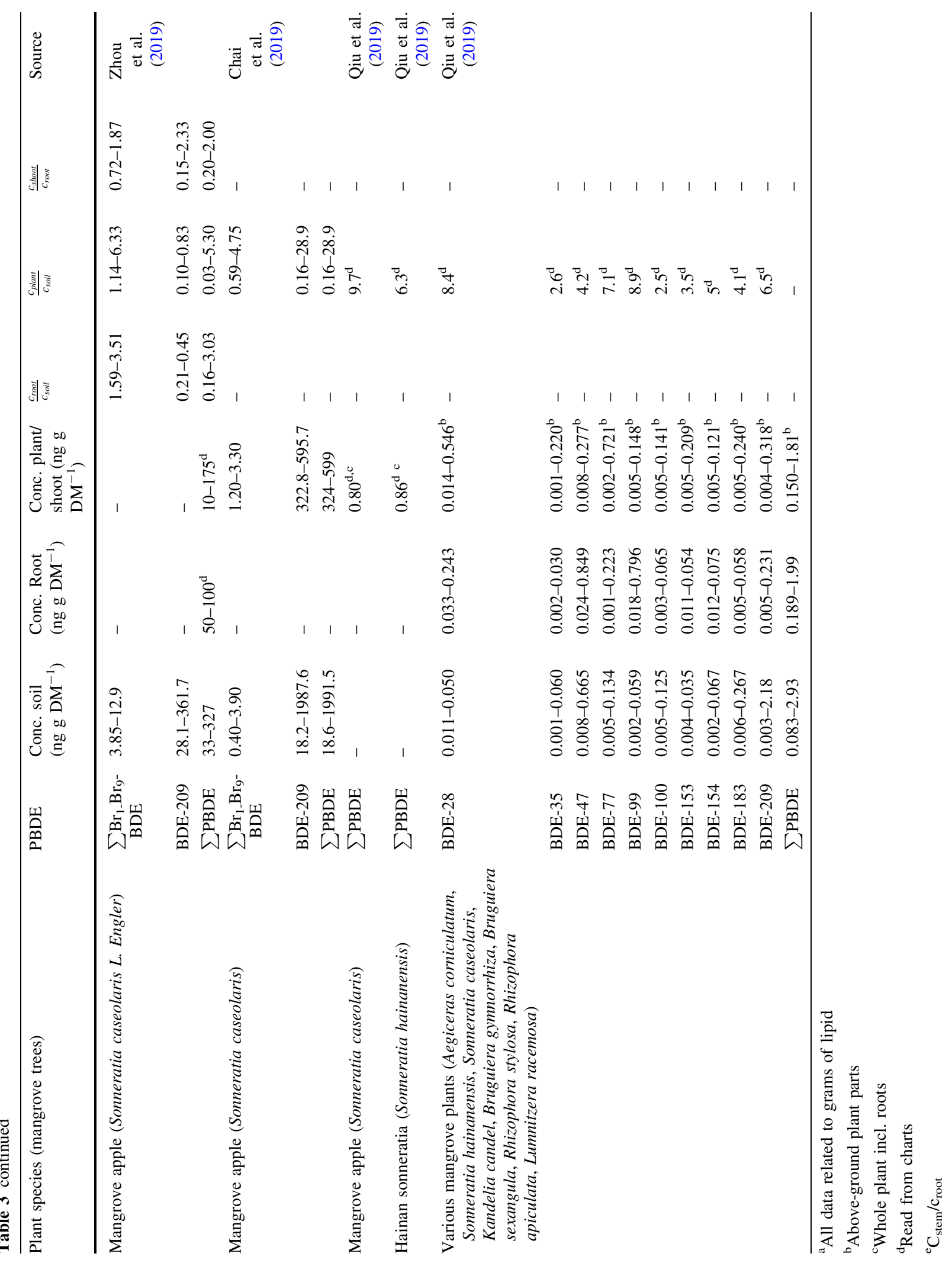


Table 4 Forest and ornamental trees

\begin{tabular}{|c|c|c|c|c|c|c|c|c|}
\hline Plant species (trees) & PBDE & $\begin{array}{l}\text { Conc. soil } \\
\left(\text { ng g DM }^{-1}\right)\end{array}$ & $\begin{array}{l}\text { Conc. root } \\
\left(\mathrm{ng} \mathrm{g}^{-1}\right. \\
\left.\mathrm{DM}^{-1}\right)\end{array}$ & $\begin{array}{l}\text { Conc. bark } \\
\left(\mathrm{ng} \mathrm{g}^{-1}\right. \\
\left.\mathrm{DM}^{-1}\right)\end{array}$ & $\frac{c_{\text {root }}}{c_{\text {soil }}}$ & $\frac{c_{\text {plant }}}{c_{\text {soil }}}$ & $\frac{c_{\text {bark }}}{c_{\text {root }}}$ & Source \\
\hline $\begin{array}{l}\text { Coniferous trees (pine, fir, } \\
\text { spruce) }\end{array}$ & $\Sigma \mathrm{PBDE}$ & - & - & $2.12-190^{\mathrm{a}}$ & - & - & - & $\begin{array}{l}\text { Salamova } \\
\text { and } \\
\text { Hites } \\
(2013)\end{array}$ \\
\hline \multirow[t]{5}{*}{$\begin{array}{l}\text { Weymoth pine (Pinus } \\
\text { strobus) }\end{array}$} & $\Sigma \mathrm{PBDE}$ & - & - & $0.989-15.1$ & - & - & - & $\begin{array}{l}\text { Salamova } \\
\text { and } \\
\text { Hites } \\
(2010)\end{array}$ \\
\hline & BDE-47 & - & - & $0.225-2.69$ & - & - & - & \\
\hline & BDE-99 & - & - & $0.368-3.86$ & - & - & - & \\
\hline & $\begin{array}{r}\text { BDE- } \\
100\end{array}$ & - & - & $0.103-1.01$ & - & - & - & \\
\hline & $\begin{array}{r}\text { BDE- } \\
209\end{array}$ & - & - & $0.103-5.14$ & - & - & - & \\
\hline $\begin{array}{r}\text { Japanese black pine } \\
\text { (Pinus thunbergii) }\end{array}$ & $\begin{array}{r}\text { BDE- } \\
209\end{array}$ & $1.17-5.42^{\mathrm{b}}$ & $1.60-4.55^{\mathrm{b}}$ & $0.40-5.95^{\mathrm{b}}$ & $0.33-2.99$ & $0.07-3.18$ & $0.25-1.31$ & $\begin{array}{l}\text { Wen et al. } \\
\text { (2019) }\end{array}$ \\
\hline \multirow{8}{*}{$\begin{array}{l}\text { Butterfly tree (Bauhinia } \\
\text { purpurea Linn), white } \\
\text { champaca (Michelia } \\
\text { alba DC.), Chinese } \\
\text { banyan (Ficus } \\
\text { microcarpa } \text { var. } \\
\text { pusillifolia) }\end{array}$} & BDE-28 & - & - & - & - & $0.50-100^{\mathrm{b}}$ & - & $\begin{array}{c}\text { Ding et al. } \\
\text { (2014) }\end{array}$ \\
\hline & BDE-47 & - & - & - & - & $0.25-50^{\mathrm{b}}$ & - & \\
\hline & BDE-99 & - & - & - & - & $0.13-79^{\mathrm{b}}$ & - & \\
\hline & $\begin{array}{r}\text { BDE- } \\
100\end{array}$ & - & - & - & - & $0.13-79^{\mathrm{b}}$ & - & \\
\hline & $\begin{array}{r}\text { BDE- } \\
153\end{array}$ & - & - & - & - & $0.50-792^{b}$ & - & \\
\hline & $\begin{array}{r}\text { BDE- } \\
154\end{array}$ & - & - & - & - & $0.13-79^{\mathrm{b}}$ & - & \\
\hline & $\begin{array}{c}\text { BDE- } \\
183\end{array}$ & - & - & - & - & $0.05-32^{\mathrm{b}}$ & - & \\
\hline & $\begin{array}{r}\text { BDE- } \\
209\end{array}$ & - & - & - & - & $0.05-2.0^{\mathrm{b}}$ & - & \\
\hline \multirow[t]{8}{*}{ Willow (Salix L.) } & BDE-28 & $0.004-0.105$ & - & $0.015-0.063$ & - & $1.04-2.18^{\mathrm{c}}$ & - & $\begin{array}{c}\text { Chen et al. } \\
(2020)\end{array}$ \\
\hline & BDE-47 & n.d. -0.095 & - & $0.005-0.061$ & - & $0.54-1.50^{\mathrm{c}}$ & - & \\
\hline & BDE-99 & n.d. -0.219 & - & n.d. -0.018 & - & $1.26-1.30^{\mathrm{c}}$ & - & \\
\hline & $\begin{array}{r}\text { BDE- } \\
100\end{array}$ & n.d. -0.100 & - & n.d. -0.019 & - & - & - & \\
\hline & $\begin{array}{r}\text { BDE- } \\
153\end{array}$ & n.d. -0.089 & - & n.d & - & - & - & \\
\hline & $\begin{array}{r}\text { BDE- } \\
154\end{array}$ & n.d. -0.110 & - & n.d & - & - & - & \\
\hline & $\begin{array}{c}\text { BDE- } \\
183\end{array}$ & n.d. -0.246 & - & n.d & - & - & - & \\
\hline & $\begin{array}{c}\text { BDE- } \\
209\end{array}$ & $0.505-64.3$ & - & $0.169-5.96$ & - & $0.12-0.81^{\mathrm{c}}$ & - & \\
\hline
\end{tabular}


Table 4 continued

\begin{tabular}{|c|c|c|c|c|c|c|c|c|}
\hline Plant species (trees) & PBDE & $\begin{array}{l}\text { Conc. soil } \\
\left(\mathrm{ng} \mathrm{g} \mathrm{DM}^{-1}\right)\end{array}$ & $\begin{array}{l}\text { Conc. root } \\
\left(\mathrm{ng} \mathrm{g}^{-1}\right) \\
\left.\mathrm{DM}^{-1}\right)\end{array}$ & $\begin{array}{l}\text { Conc. bark } \\
\left(\mathrm{ng} \mathrm{g}^{-1}\right) \\
\left.\mathrm{DM}^{-1}\right)\end{array}$ & $\frac{c_{\text {root }}}{c_{\text {soil }}}$ & $\frac{c_{\text {plant }}}{c_{\text {soil }}}$ & $\frac{c_{\text {bark }}}{c_{\text {root }}}$ & Source \\
\hline & $\begin{array}{l}\sum \text { Hepta- } \\
\text { BDE }\end{array}$ & $0.024-0.197$ & - & $0.028-0.082$ & - & $0.22-1.56^{\mathrm{c}}$ & - & \\
\hline & $\begin{array}{c}\Sigma \text { Okta- } \\
\text { BDE }\end{array}$ & $1.25-13.3$ & - & $0.490-1.73$ & - & $0.12-0.83^{\mathrm{c}}$ & - & \\
\hline $\begin{array}{l}\text { Magnolie (Magnolia } \\
\text { grandiflora) }\end{array}$ & $\Sigma \mathrm{PBDE}$ & $36.4-5393.72$ & - & $9.3-266^{\mathrm{b}}$ & - & $0.05-0.26$ & - & $\begin{array}{l}\text { Gao et al. } \\
\text { (2019) }\end{array}$ \\
\hline $\begin{array}{l}\text { Echte Trauerweide (Salix } \\
\text { babylonica) }\end{array}$ & $\Sigma$ PBDE & $36.4-5393.72$ & - & $5.8-179^{\mathrm{b}}$ & - & $0.03-0.16$ & - & $\begin{array}{c}\text { Gao et al. } \\
\text { (2019) }\end{array}$ \\
\hline $\begin{array}{l}\text { Urwaldmammutbaum } \\
\text { (Metasequoia } \\
\text { glyptostroboides) }\end{array}$ & $\Sigma \mathrm{PBDE}$ & $36.4-5393.72$ & - & $6.7-145^{\mathrm{b}}$ & - & $0.03-0.18$ & - & $\begin{array}{l}\text { Gao et al. } \\
\text { (2019) }\end{array}$ \\
\hline $\begin{array}{l}\text { Himalaya-Zeder (Cedrus } \\
\text { deodara) }\end{array}$ & $\Sigma$ PBDE & $36.4-5393.72$ & - & $9.0-259^{\mathrm{b}}$ & - & $0.05-0.25$ & - & $\begin{array}{l}\text { Gao et al. } \\
\text { (2019) }\end{array}$ \\
\hline \multirow[t]{8}{*}{$\begin{array}{l}\text { Glanzliguster (Ligustrum } \\
\text { lucidum Ait.) }\end{array}$} & BDE-28 & - & - & n.d. -0.002 & - & - & - & $\begin{array}{l}\text { Graziani } \\
\text { et al. } \\
\text { (2019) }\end{array}$ \\
\hline & BDE-47 & - & - & $0.118-0.162$ & - & - & - & \\
\hline & BDE-99 & - & - & $0.043-0.059$ & - & - & - & \\
\hline & $\begin{array}{c}\text { BDE- } \\
100\end{array}$ & - & - & $0.008-0.04$ & - & - & - & \\
\hline & $\begin{array}{r}\text { BDE- } \\
153\end{array}$ & - & - & 0.004 & - & - & - & \\
\hline & $\begin{array}{r}\text { BDE- } \\
154\end{array}$ & - & - & n.d. -0.003 & - & - & - & \\
\hline & $\begin{array}{r}\text { BDE- } \\
183\end{array}$ & - & - & $0.01-0.026$ & - & - & - & \\
\hline & $\Sigma \mathrm{PBDE}$ & - & - & $0.272-0.411$ & - & - & - & \\
\hline
\end{tabular}

n.d. not detected

${ }^{\mathrm{a}}$ All data related to grams of lipid

${ }^{\mathrm{b}} \mathrm{Read}$ from charts

${ }^{\mathrm{c}} \mathrm{C}_{\text {bark }} / \mathrm{C}_{\text {soil }}$

substituted phenylureas in barley by Briggs et al. (1982). The authors showed that this correlation presupposes sufficient water solubility of the pollutants within the intrinsic mass transport system and is therefore only applicable to polar and moderately lipophilic pollutants. However, no correlation was found between the uptake of the pollutant by the roots and the transfer behavior within the plant. It was postulated that the existing membrane barriers in the roots cannot be described by simple partition coefficients. The literature data presented in Sect. 8 suggest that plant specifics may have an additional influence which further complicates or even prevents a correlation between SCF and RCF or log KOW value. Due to the inadequate recording of these plant-specific parameters, it is not possible to make a reliable predictive statement on the PBDE levels occurring in plants.

\section{RCF and TF values for specific crops}

The plant specific root concentration factors (RCF) and translocation factors (TF) compiled from previous literature data were summarized and grouped in the Tables 2, 3, 4 and 5 as follows: Lichens, mosses, 


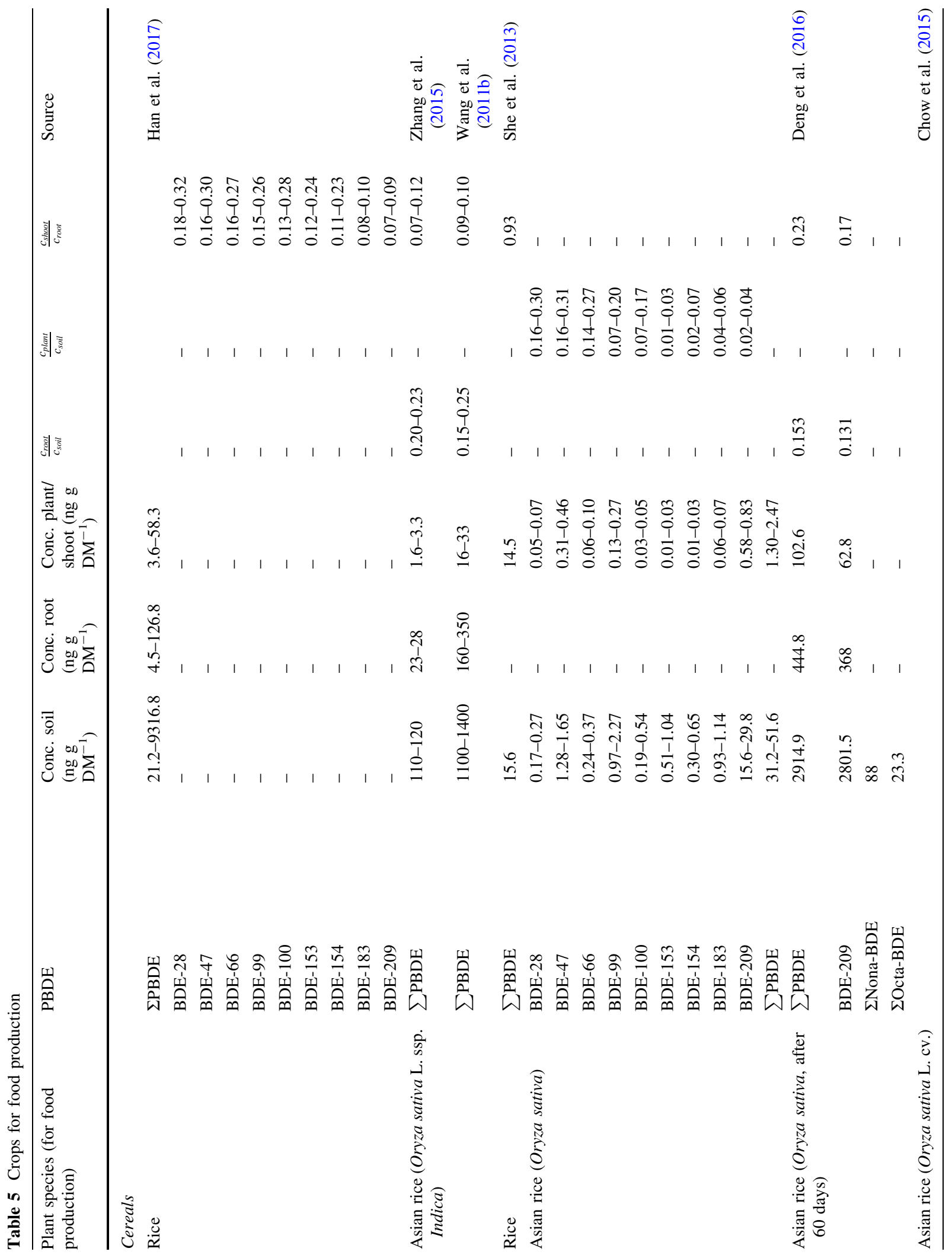




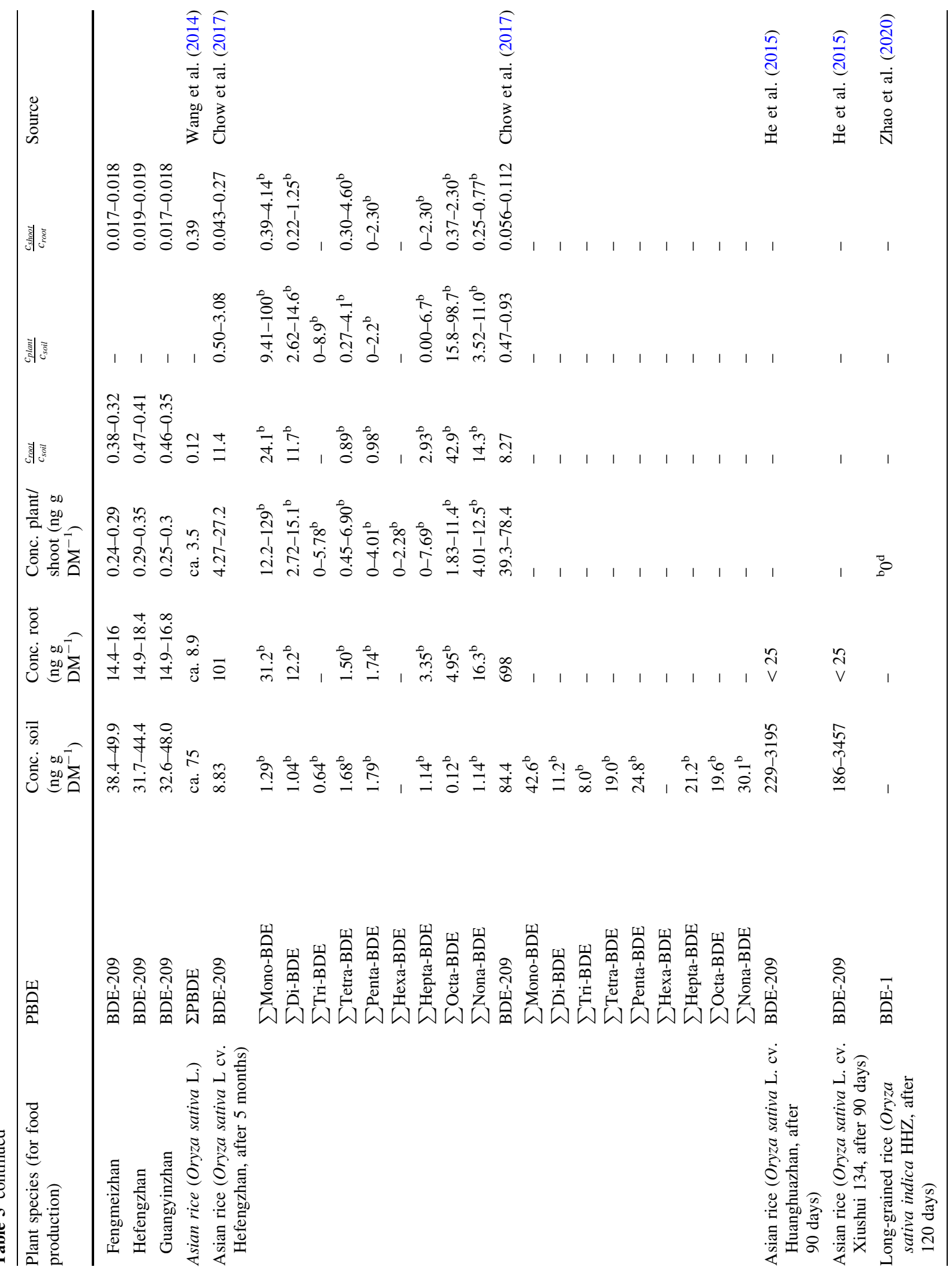




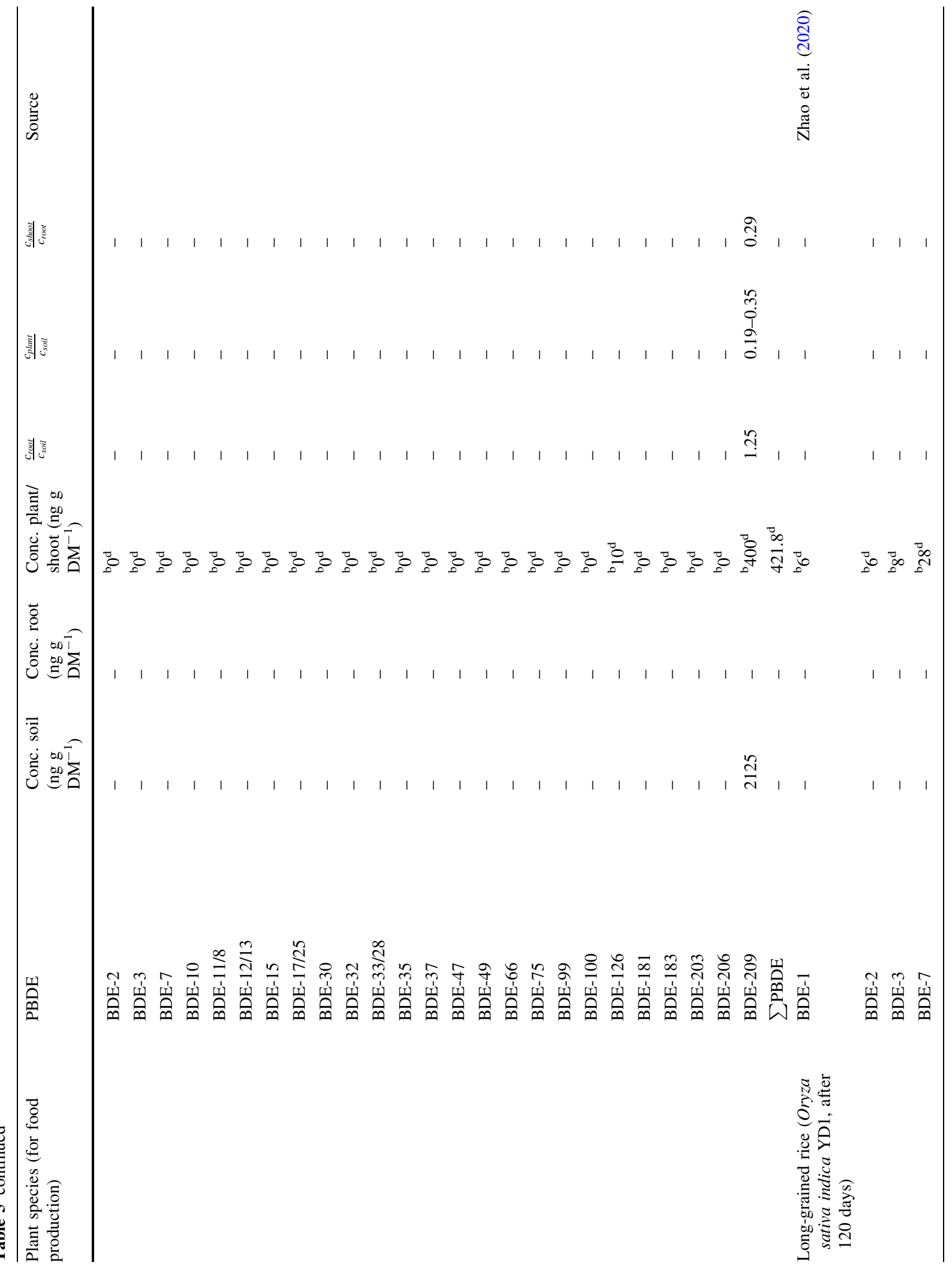




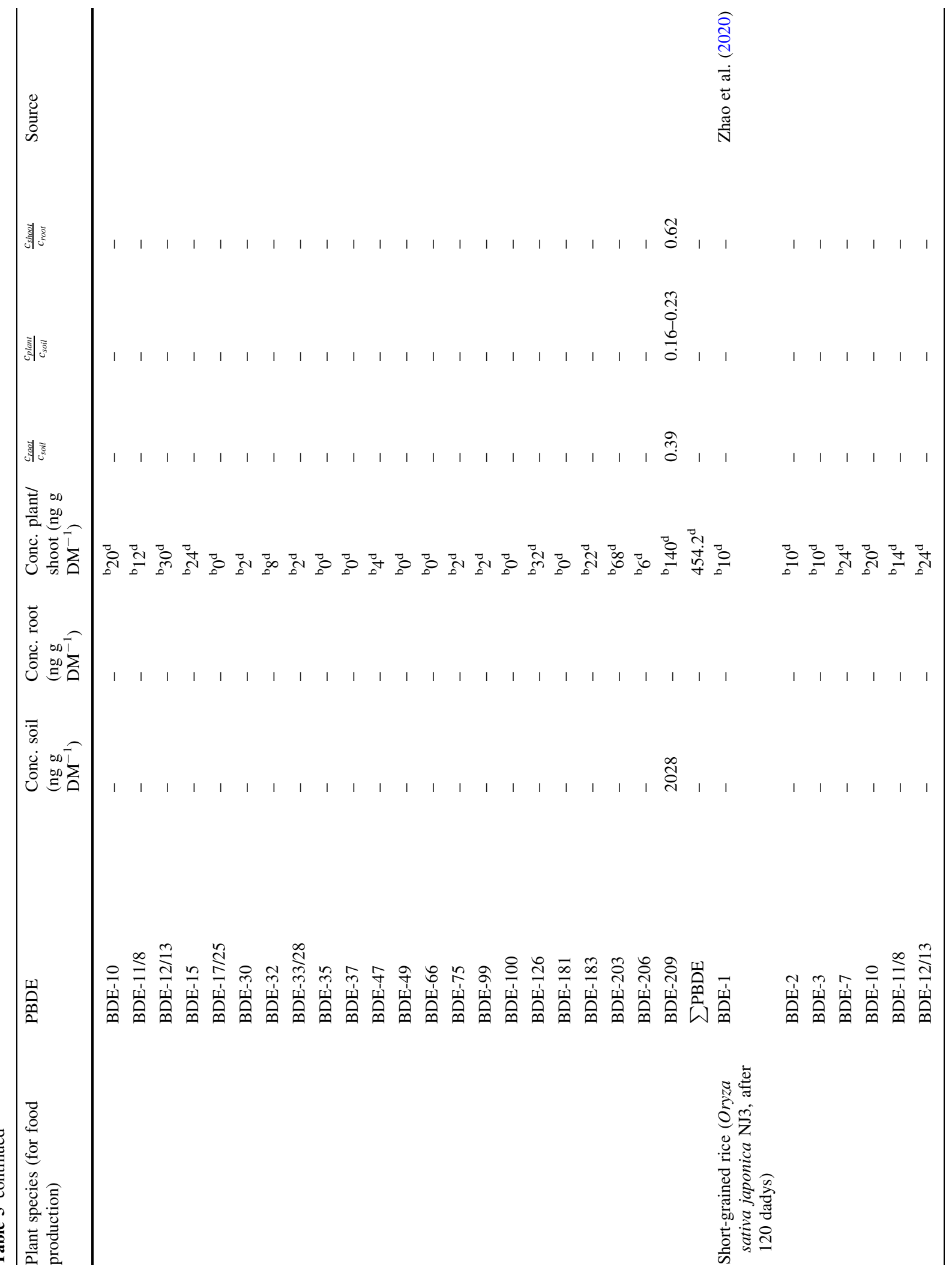




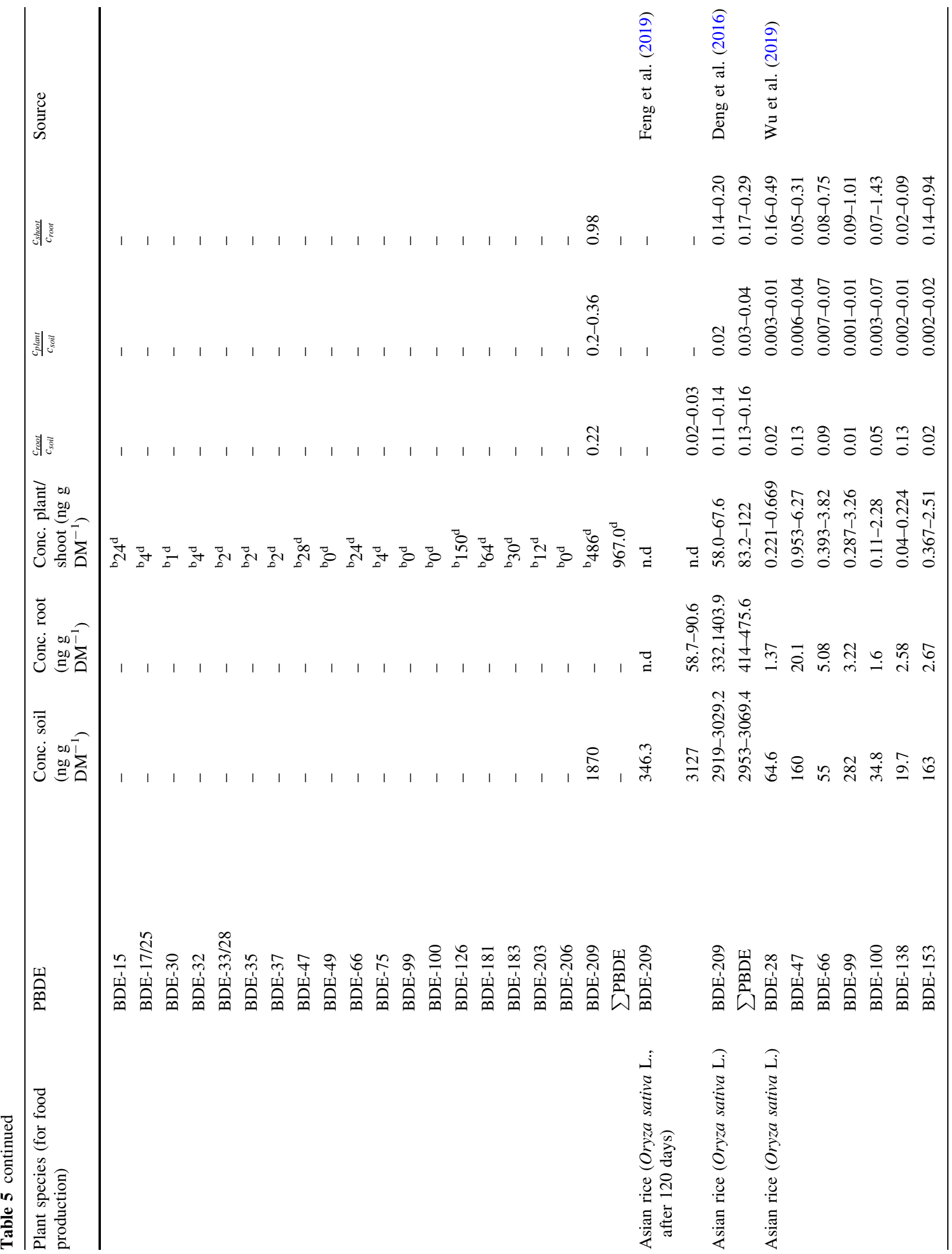




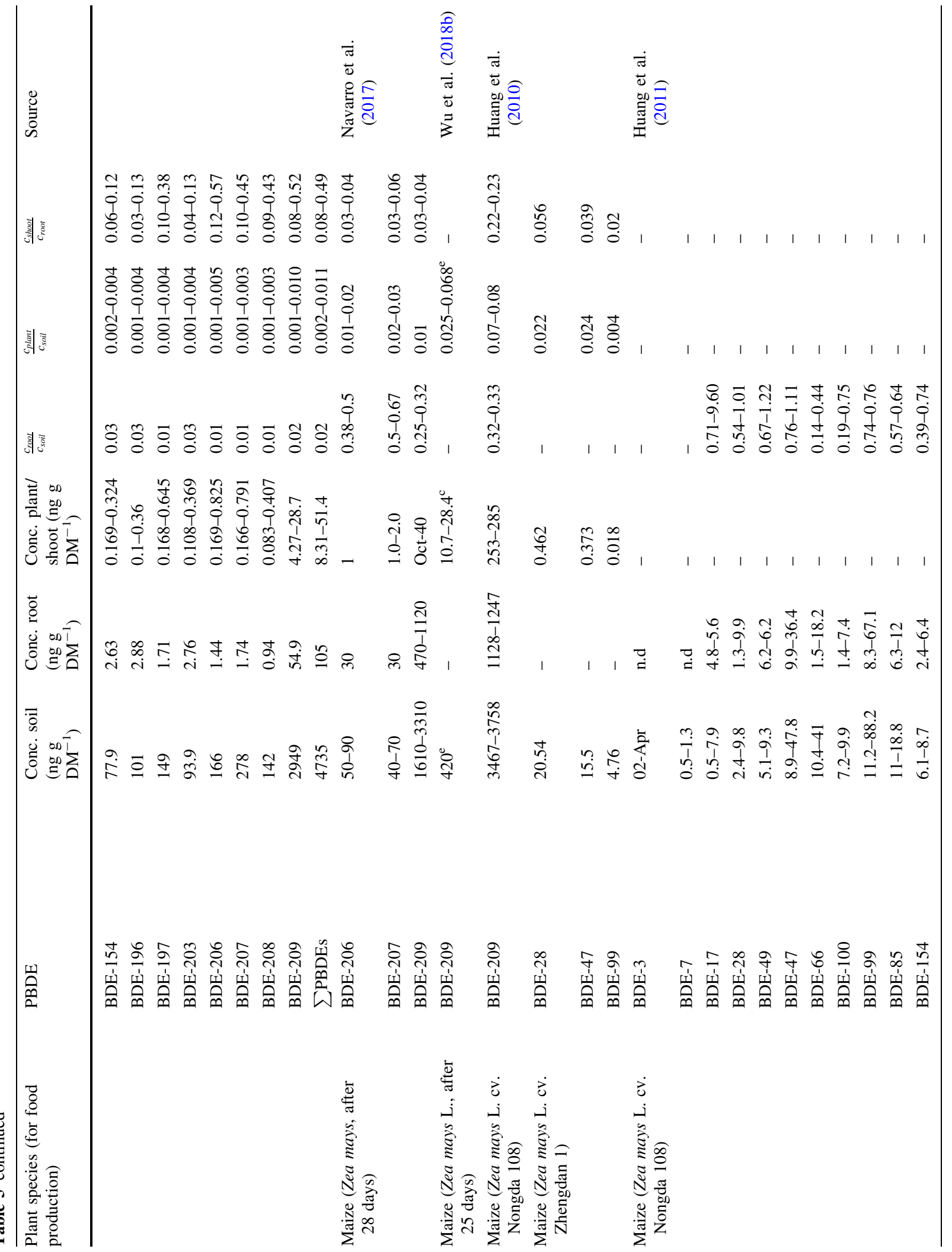




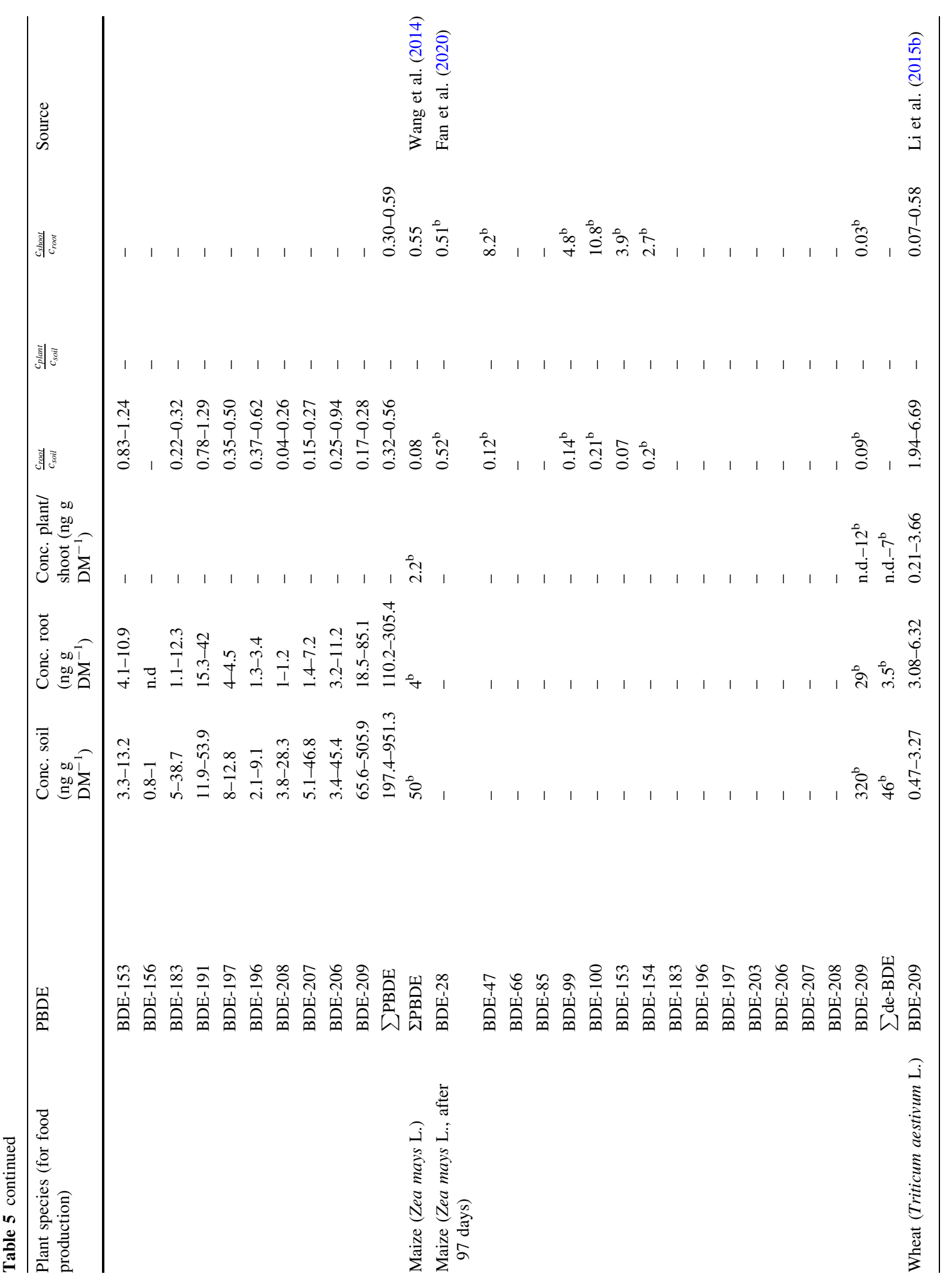




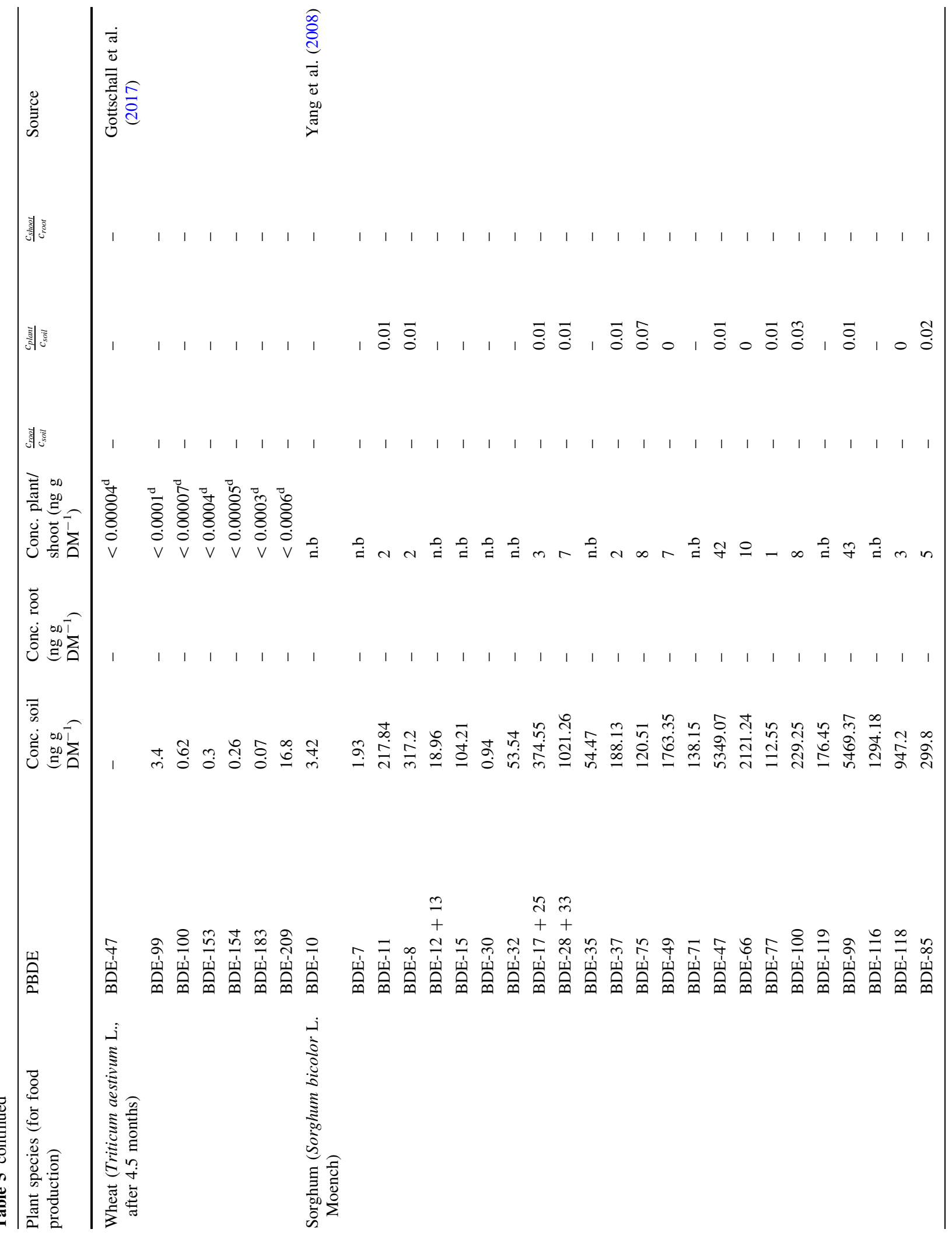




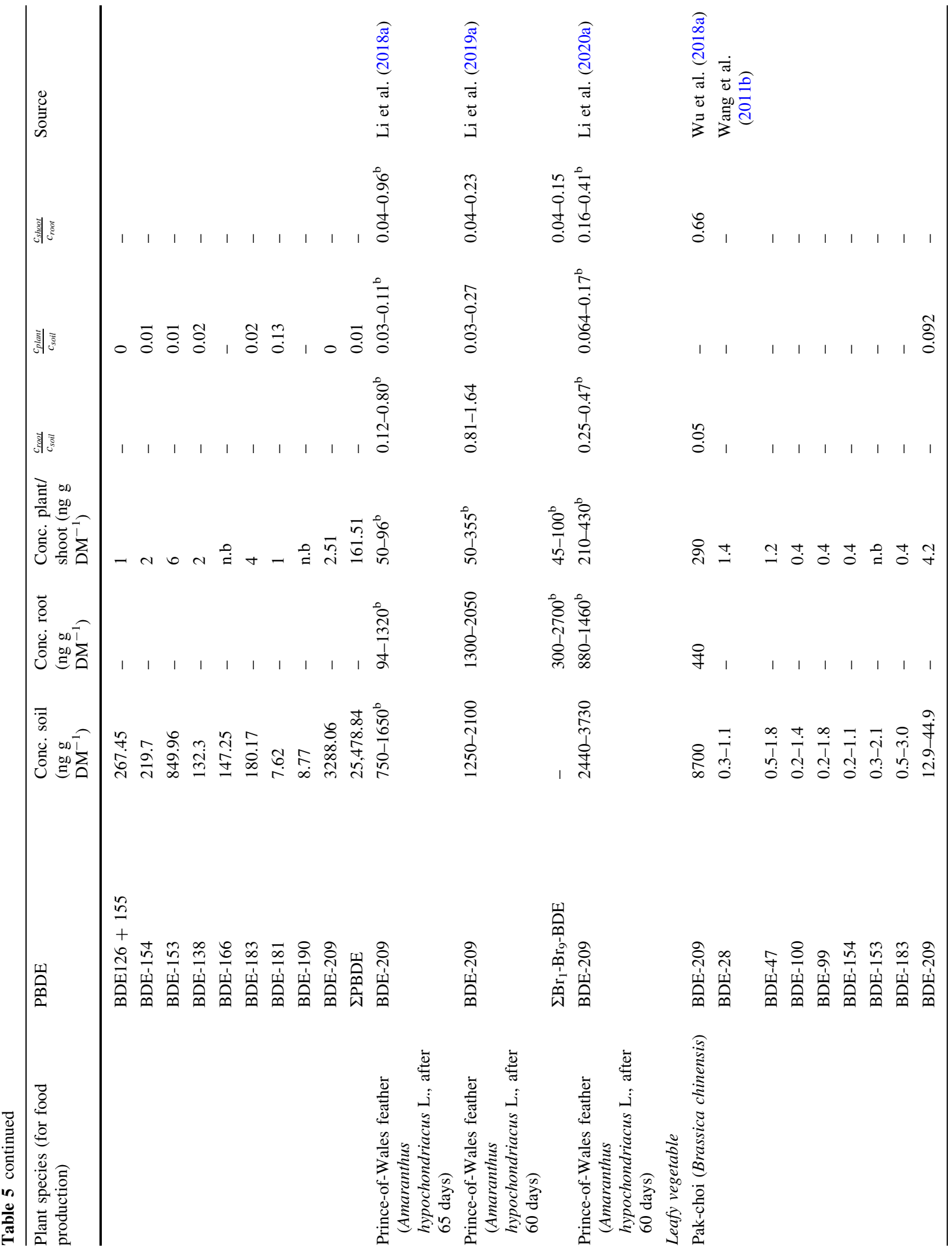




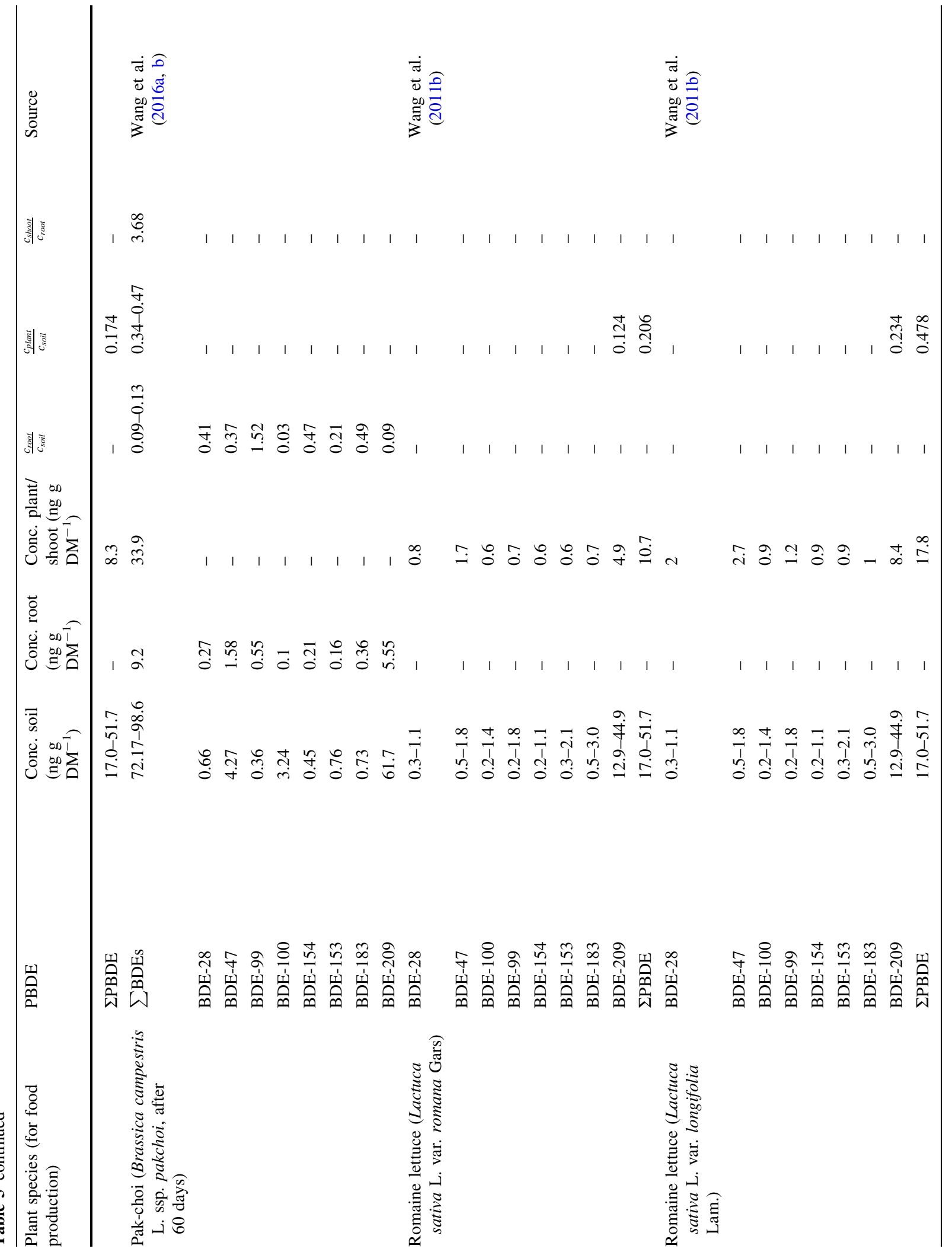




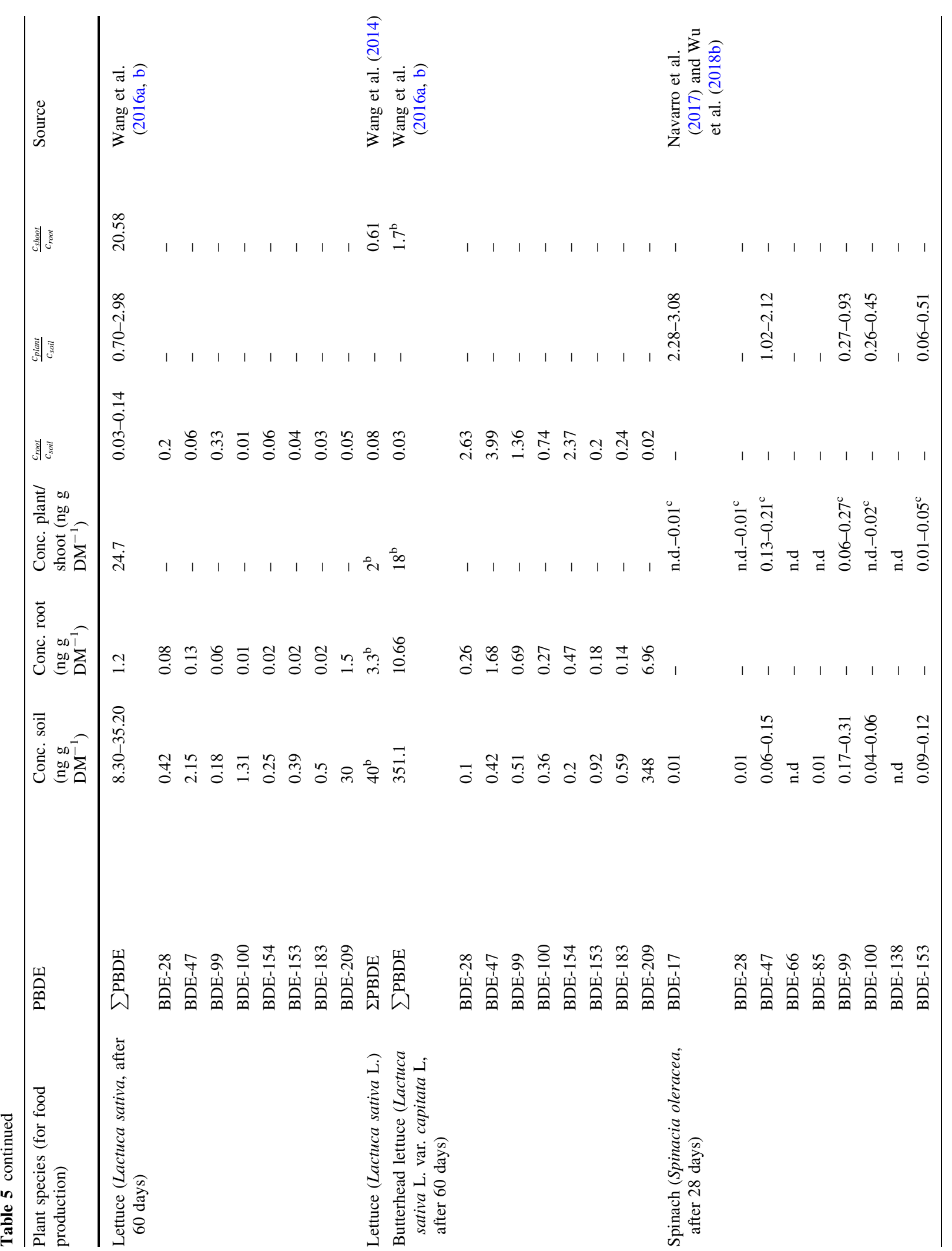




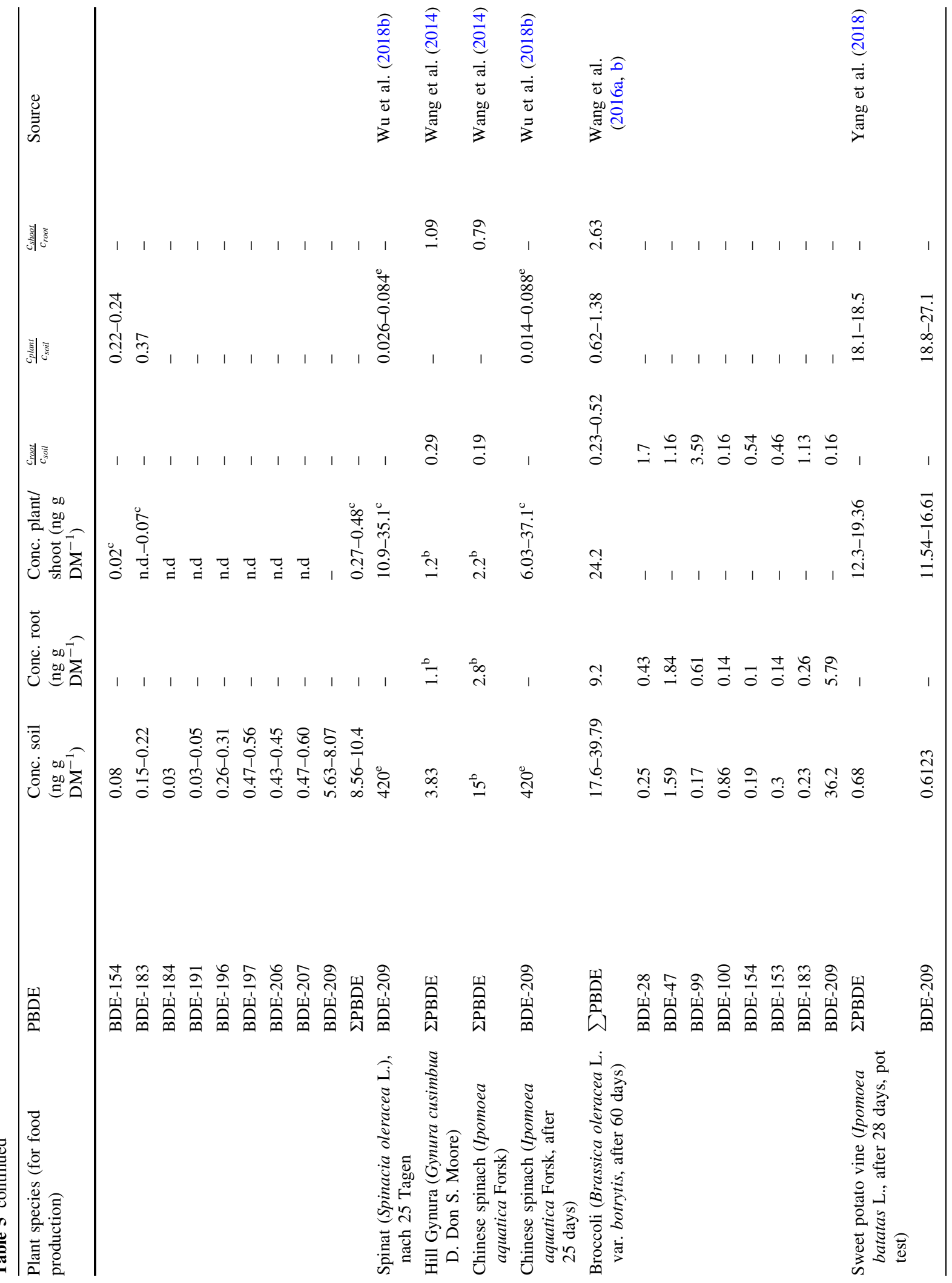




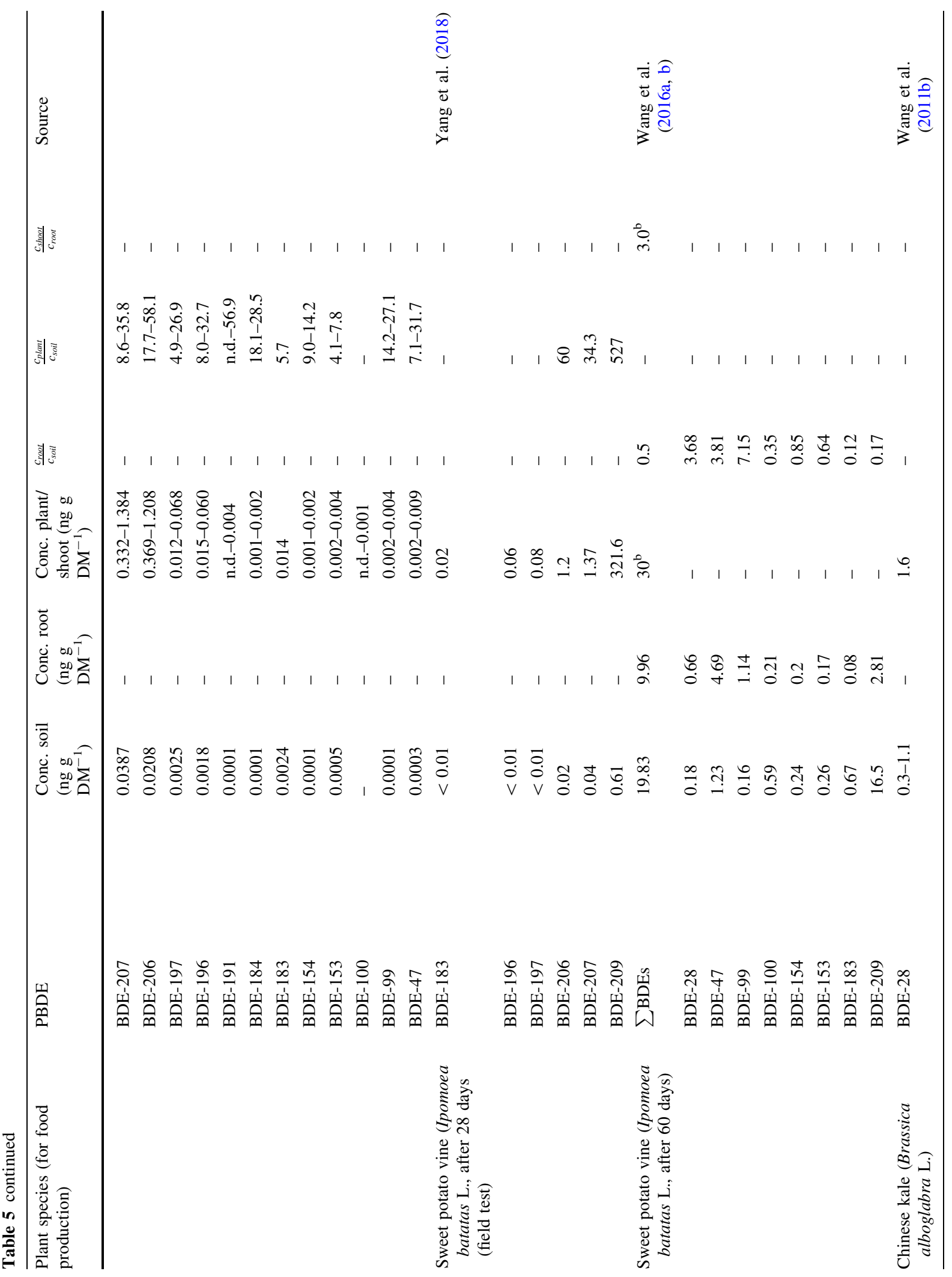




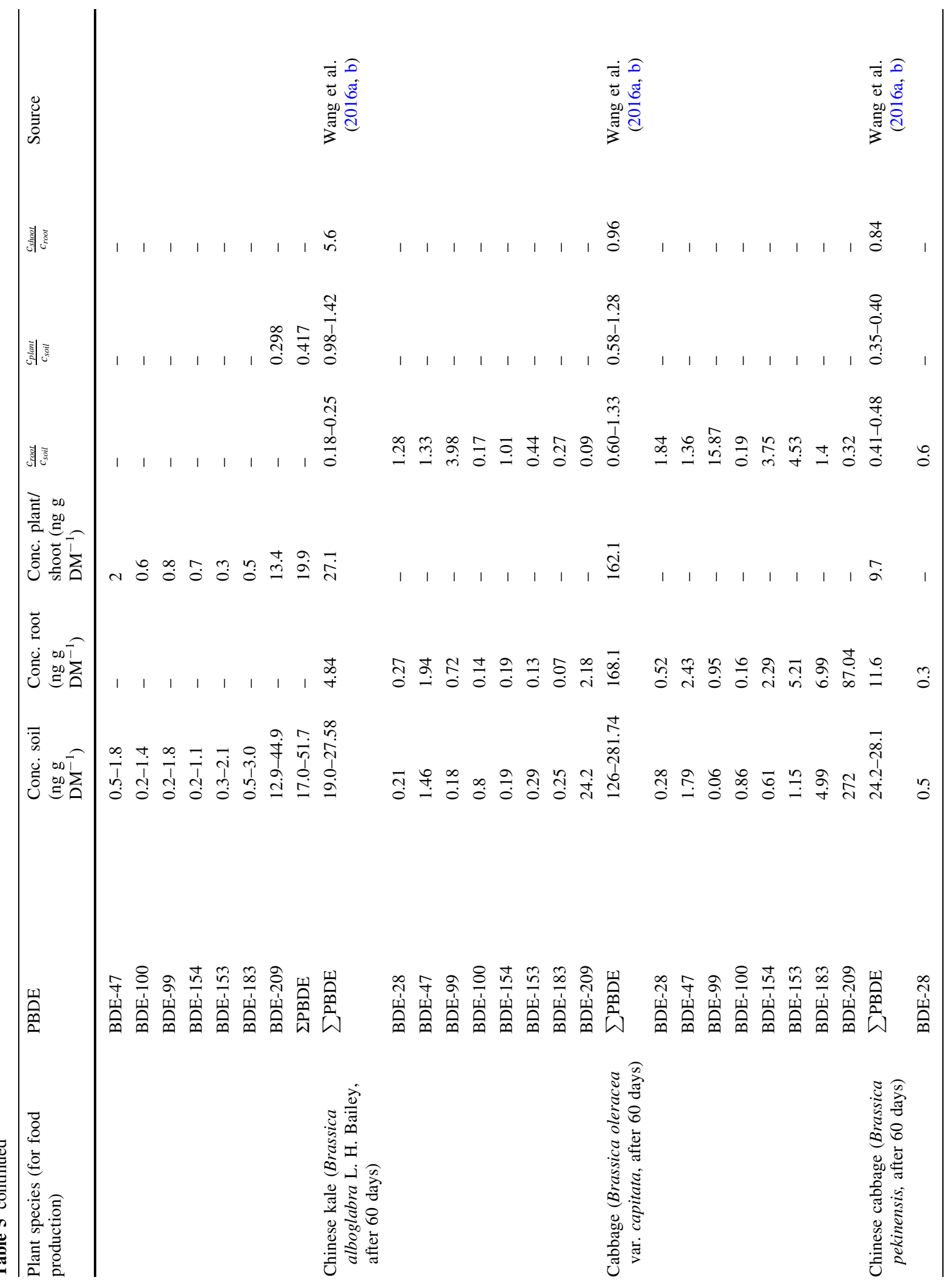




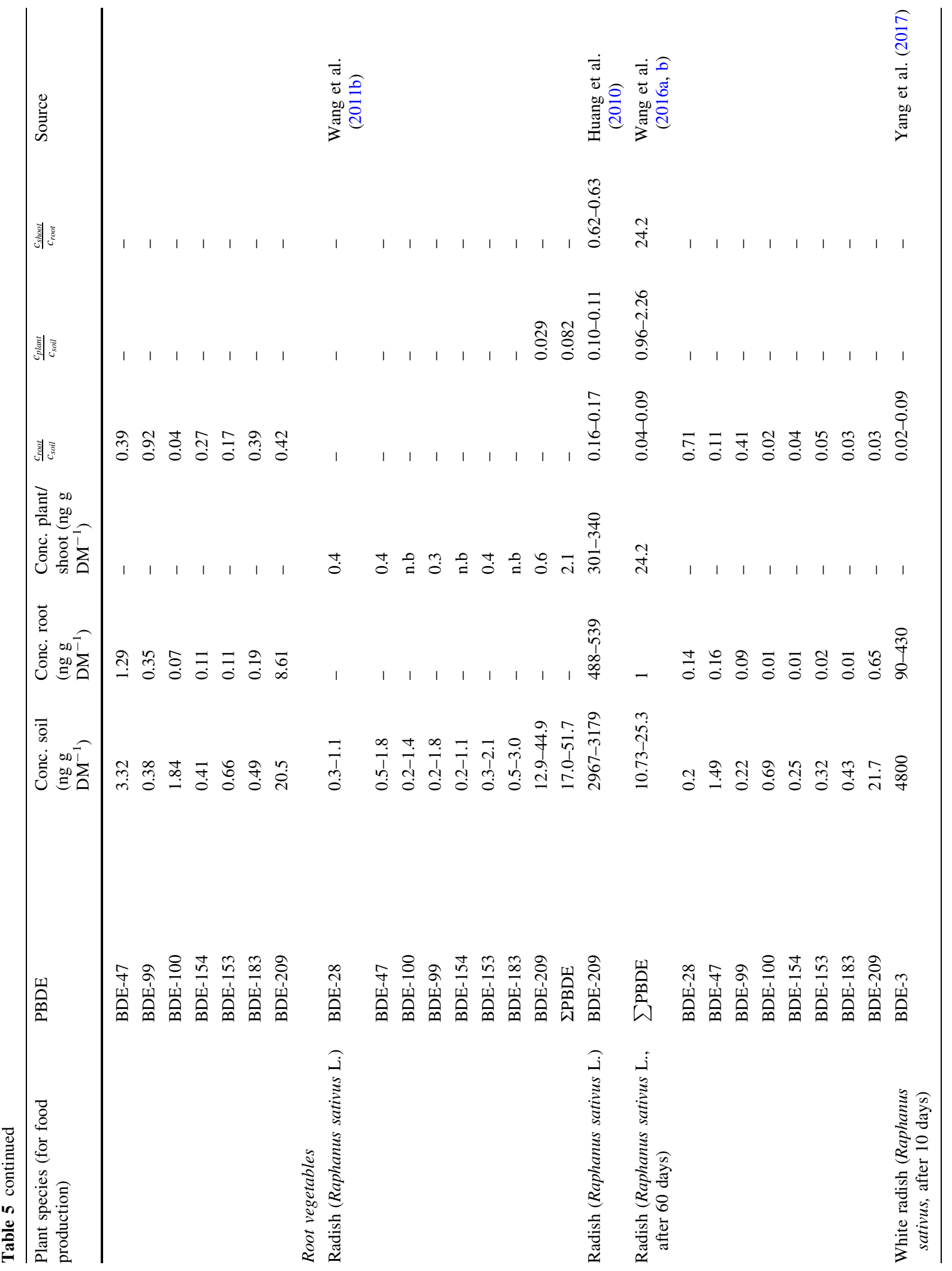




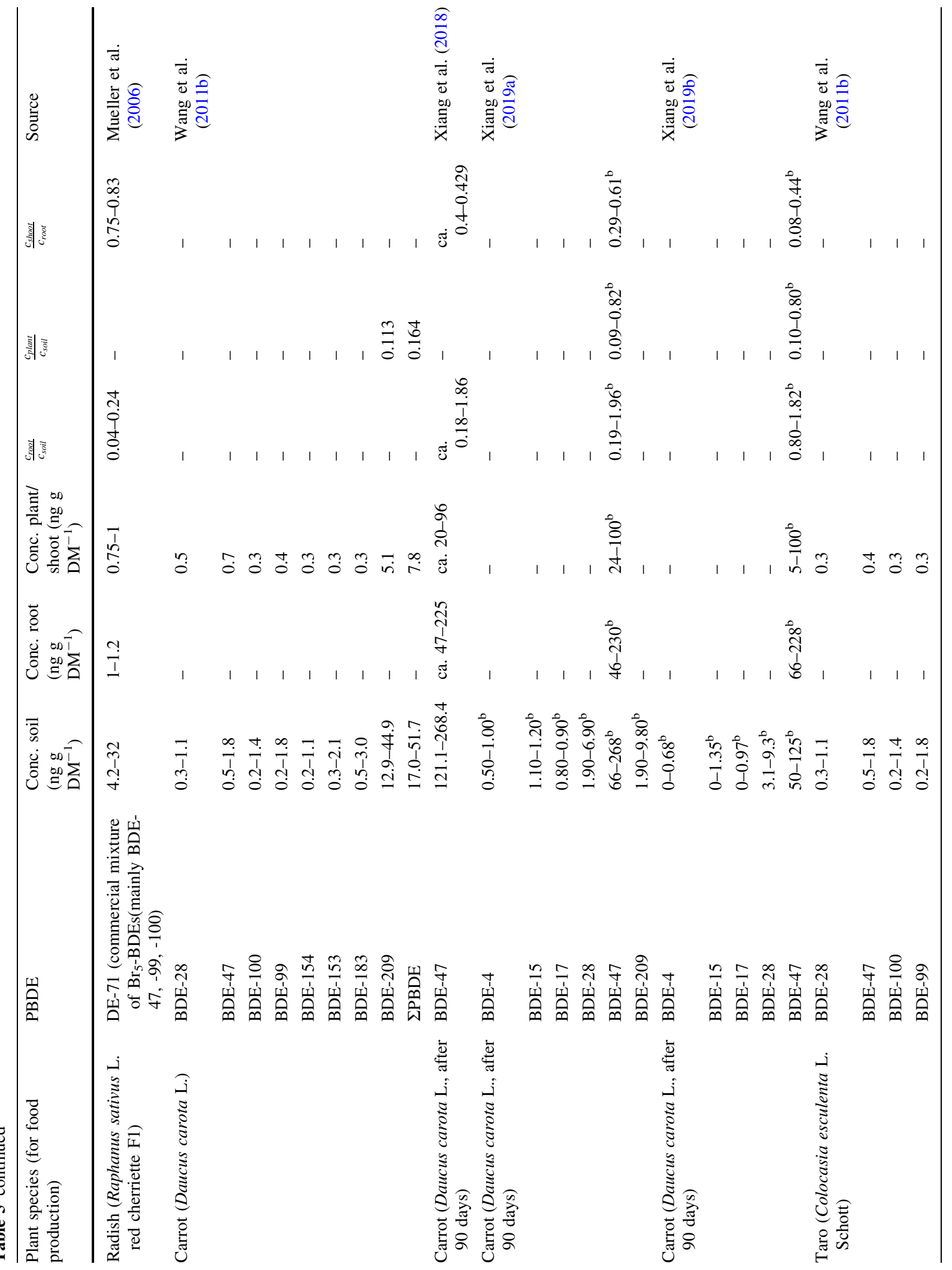




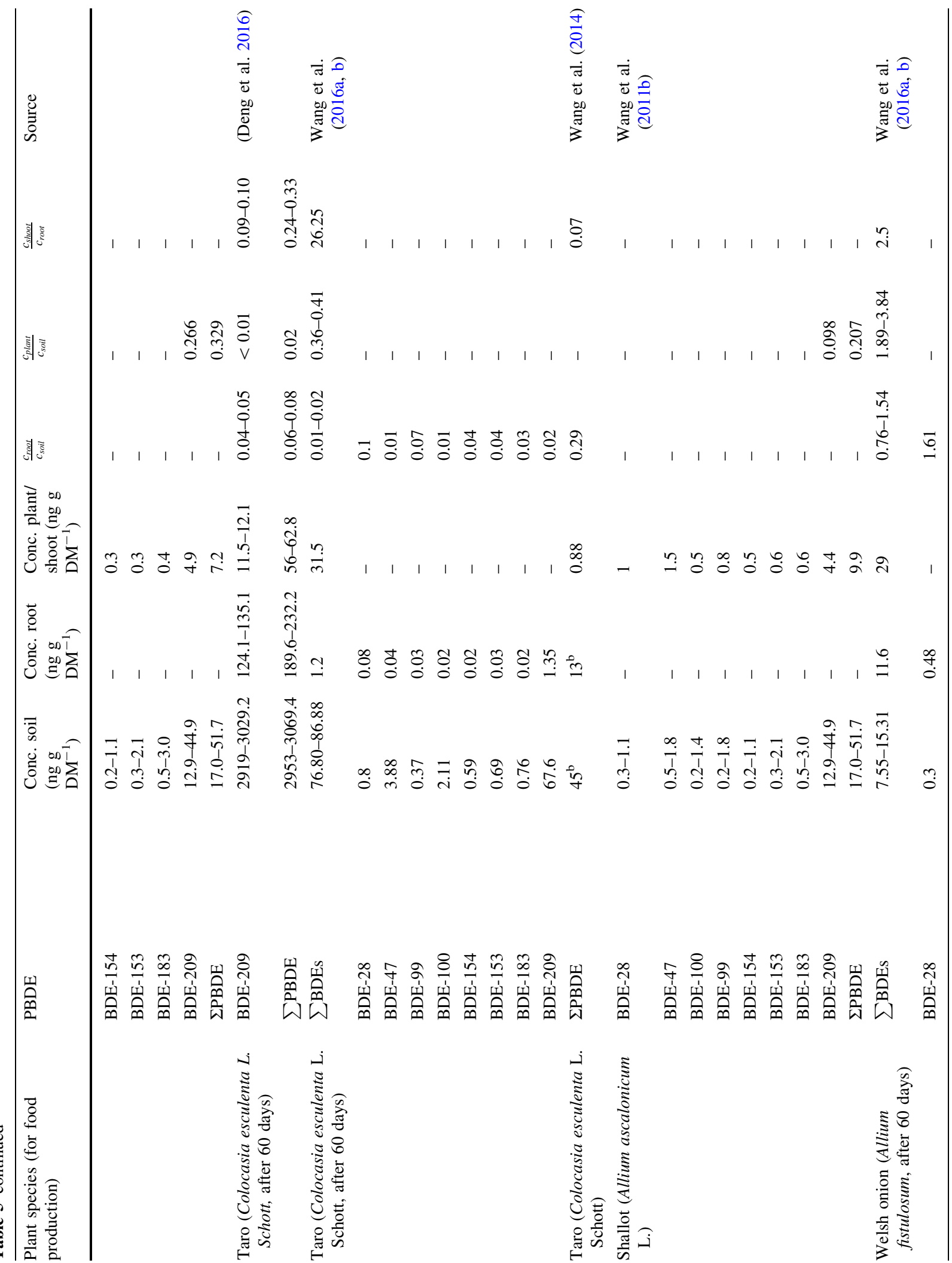




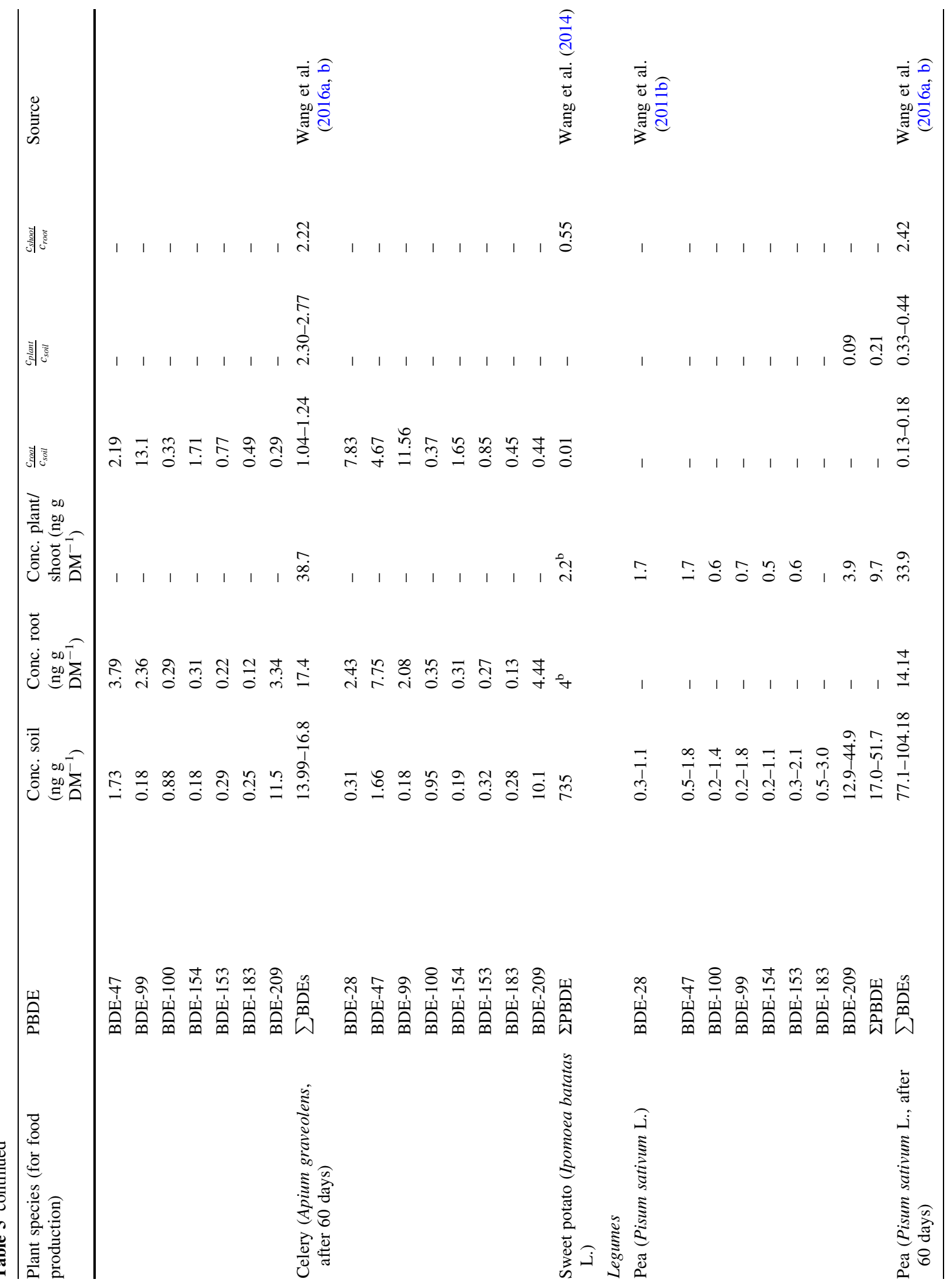




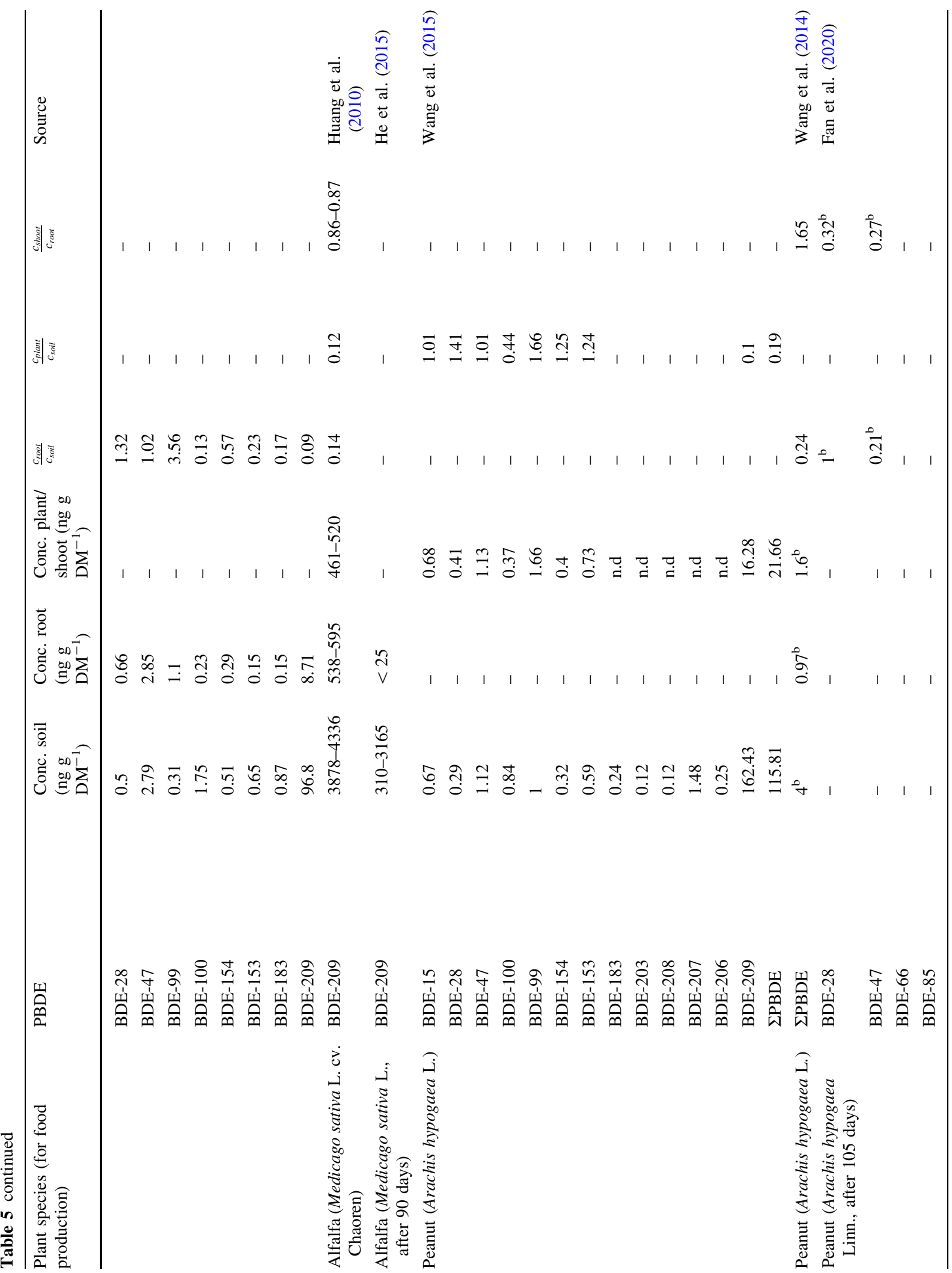




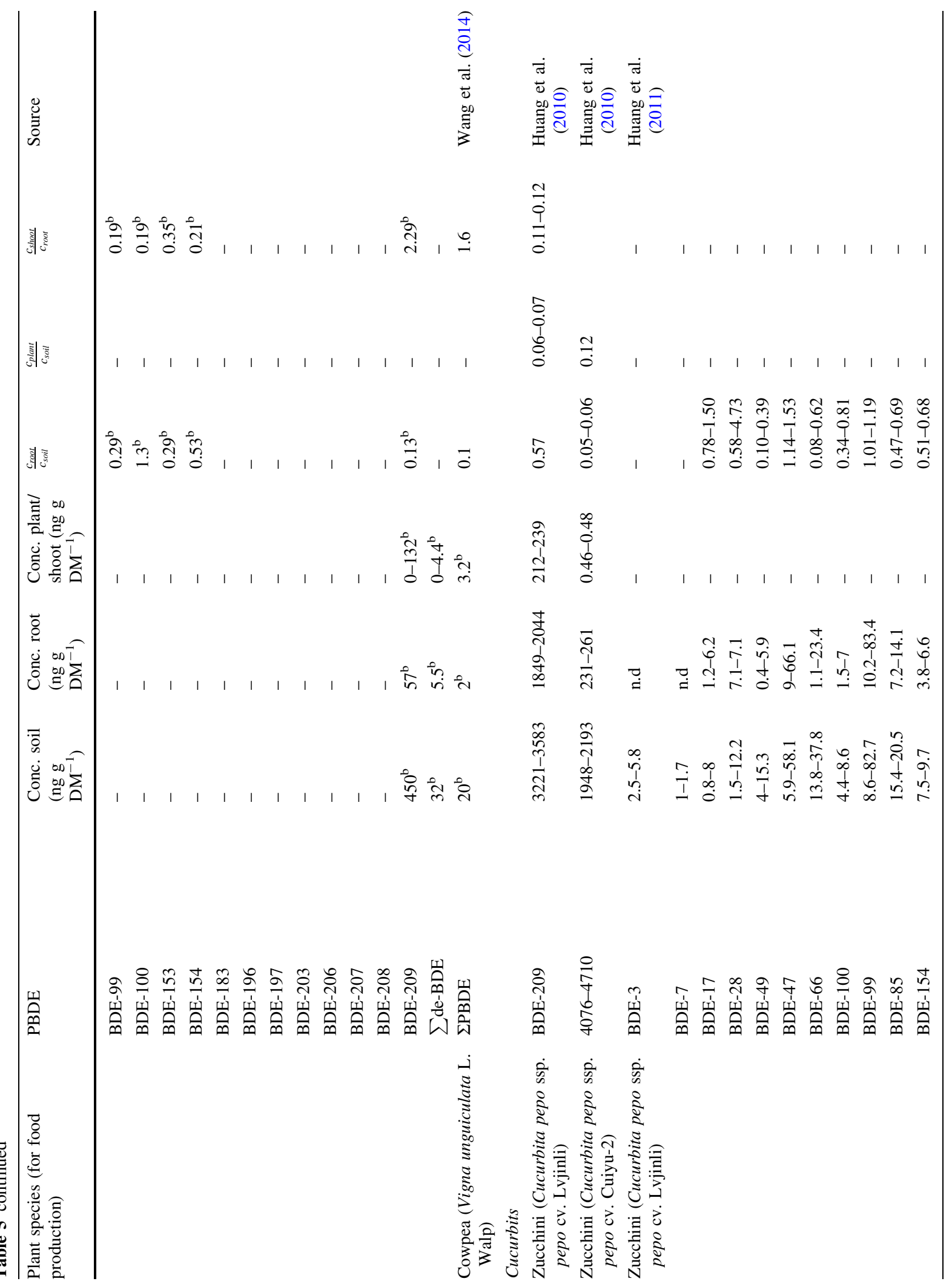




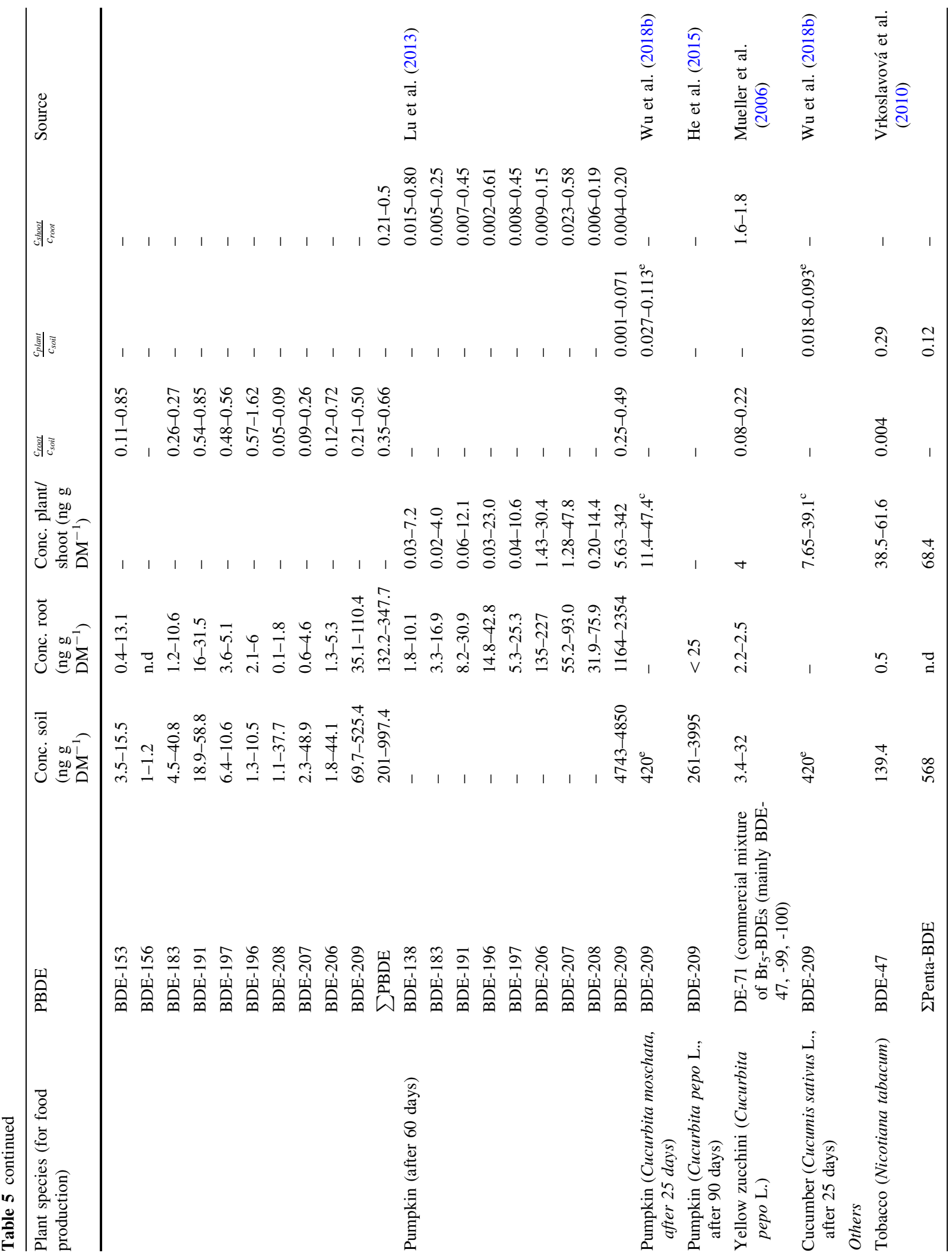




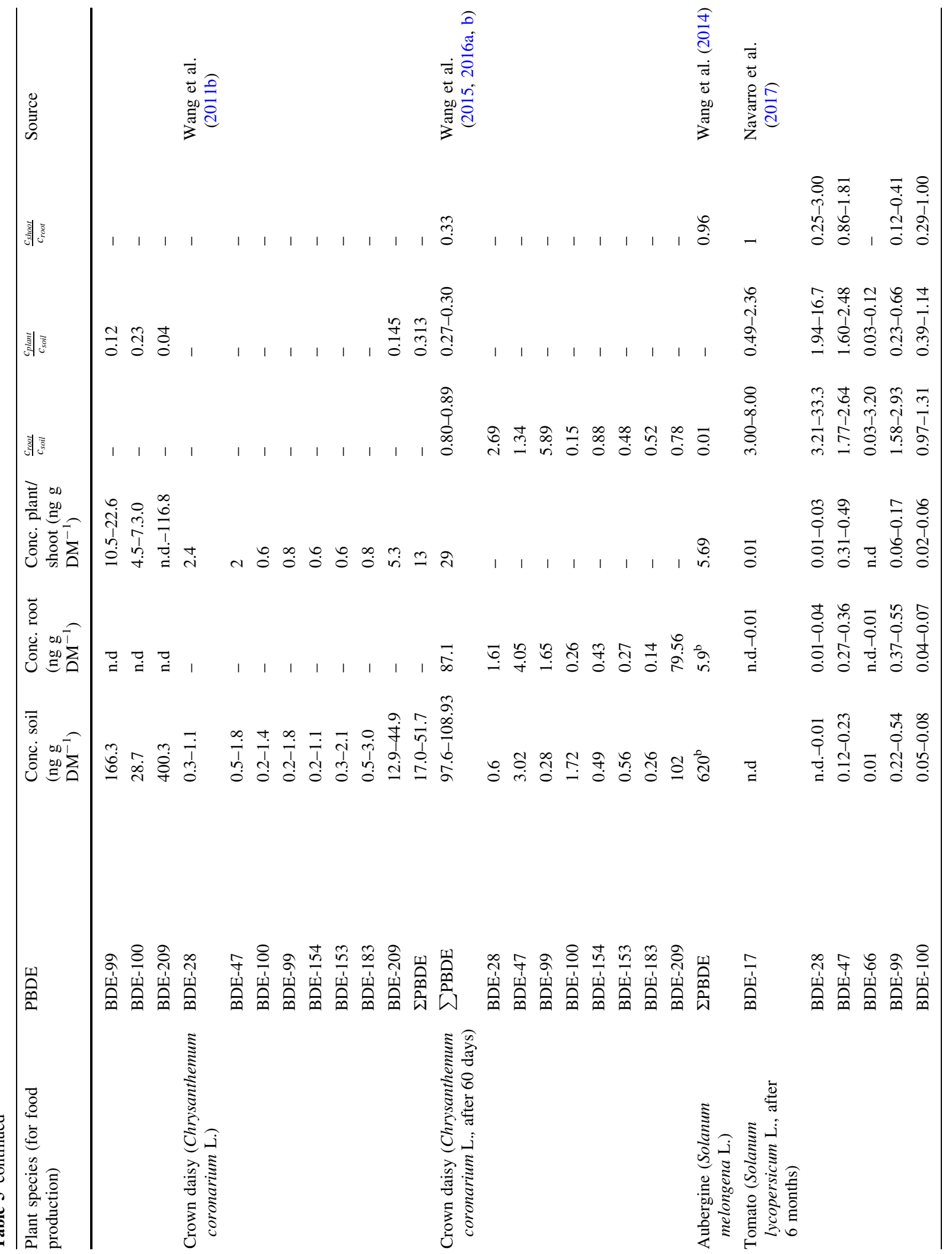




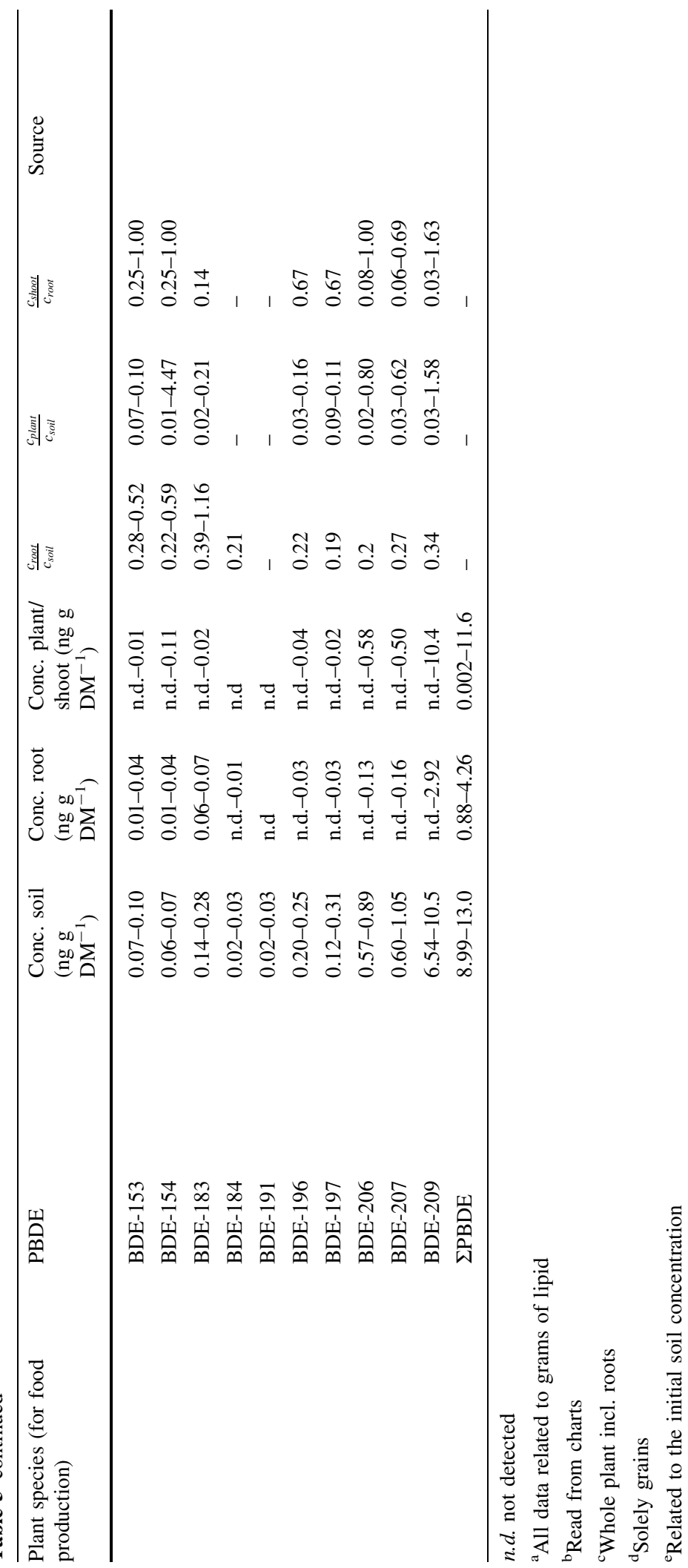


grasses, herbs and flowers (Table 2); Mangrove trees (Table 3); Forest trees and ornamental trees (Table 4); and crops for food production (Table 5). Data were partially derived from figures presented in literature.

\section{Conclusions}

PBDEs have been used as flame retardants in various products for decades. Despite legal restrictions, they are still released into the environment at high concentrations. Due to negative effects as endocrine disruptor, neurotoxicity and on reproductive capacity, knowledge of their accumulation in soil and, in particular, their uptake by plants for food production is of high relevance. PBDE plant uptake can take place both by the soil-air-plant tissue pathway and the soilsoil water-root-plant pathway. In former case, low brominated BDEs $\left(\mathrm{Br}_{2}-\mathrm{Br}_{5}\right)$ predominantly occur in gaseous form, while high-brominated BDEs $\left(\mathrm{Br}_{8^{-}}\right.$ $\mathrm{Br}_{10}$ ) are exclusively detected in particulate form. Accordingly, gaseous BDEs are almost present ubiquitously, while concentrations of particulate BDEs strongly decline with distance from the emission source.

Transport and plant uptake are strongly affected by physical and chemical properties of the BDEs (vapor pressure, octanol-water partition coefficient, air-water partition coefficient, air-plant partition coefficient), environmental factors (i.e. temperature, wind velocity, amount of rain, temporal rain distribution, gas deposition kinetics, particle-bound deposition kinetics), large-scale atmospheric transport processes, plant properties (i.e. species, lipid content, foliage morphology, non-lipid plant parts, bark thickness, sugar content, fiber content) as well as terrestrial rhizospheres. During atmospheric transport PBDEs are subject to UV-induced transformation processes like debromination, hydroxylation and ring closure to dibenzofurans. Due to the lipophilic character, PBDEs are characterized by an increased adsorption on lipophilic soil matrices and, thus, by a lack of mobility and low uptake via the soil-soil water-root-plant pathway. Hence, uptake and intrinsic transport is only expected for low brominated BDEs. Therefore, declining concentrations of PBDEs could be detected from soil via roots via shoots and fruit, i.e. both RCF and $\mathrm{TF}$ value are negatively correlated with the $\log$ $\mathrm{K}_{\mathrm{OW}}$ value. Corresponding studies therefore showed a dominant human intake of PBDEs by respiration and inhalation of dust with $84 \%$, while only $16 \%$ were correlated with dietary uptake.

The actual exposure of vegetarian foods to PBDEs depends on many parameters, where mineralization and detoxification mechanisms in both the soil matrix and the plant tissue significantly affect the resulting levels. The following parameters were identified as relevant for plant uptake behavior:

- The release of plant intermediates like amino acids, organic acids, sugars and exoenzymes, as occurs for example in symbiosis with rhizobia, both promotes microbial degradation of PBDEs in the soil matrix and PBDE plant uptake.

- Microbial degradation of PBDEs in soil and plant uptake are enhanced in presence of a rhizosphere.

- Atmospheric PBDE uptake is strongly influenced by the plant morphology and especially the lipid content of the shoots. PBDE levels rise with increasing lipid content.

- The PBDE plant uptake is promoted by an increase of the specific surface area of the roots or leaves.

- The lipid content of the plant can be directly correlated with the RCF value of the plant, i.e. high lipid contents in the plant roots lead to an increased PBDE uptake. In parallel, however, high root lipid levels evoke immobilization of PBDEs in the roots and thus a low TF value. Basically, the higher the plant's lipid content the higher the PBDE uptake and thus PBDE load in consumable parts of the plant and subsequent food products.

- PBDE immobilization and accumulation is promoted by increasing TOC levels in soil (e.g. through the introduction of compost, sewage sludge, digestates, biochar), i.e. PBDE plant uptake decreases with increasing TOC levels.

- There is no effect of increasing DOC levels on PBDE plant uptake due to the lack of solubility. However, terrestrial microbial biodegradation is supported.

- With PBDE loads of up to $2.5 \mathrm{w} \%$, sewage sludge represents an important source of PBDEs causing a considerable increase in soil pollution. In contrast, the PBDE load of compost and digestates is low, i.e. soil pollution effects are negligible.

- High lipophilic alternate soil conditioners enforce immobilization and therefore reduced plant uptake of PBDEs. 
- With increasing soil moisture, evaporative PBDE losses decrease on the one hand and immobilization of PBDEs increases on the other hand. Plant uptake thus decreases with increasing soil moisture.

- Ionic additives as well as nanoscale organic substances (i.e. graphite powder, carbon nanotubes) both increase mobilization and plant uptake of PBDEs due to surfactant effects and the particle size. The same effect is observed for solubilizers.

- Macroelements such as nitrate favor the terrestrial degradation of PBDEs through their function as an alternative electron acceptor, which indirectly reduces the plant's load.

- Regarding the low concentration levels, trace elements have no effect on PBDE plant uptake. However, microbial transformation of PBDEs in soil is enhanced and, thus, PBDE load is reduced.

- The presence of heavy metals at high levels indirectly enforces PBDE plant uptake due to the inhibition of the terrestrial microbial degradation.

- Predictive mathematical models exist, which allow a very good prediction of the RCF value with a minimum of input parameters. In contrast, the prediction of SCF and TF values is not appropriate due to the inadequate recording of plant-specific parameters.

- In accordance to Lipinski's 'Law of $5^{\prime} \mathrm{Br}_{4}$ - and $\mathrm{Br}_{5}$-BDE congeners show the highest RCF levels, while high TF factors require higher polarity. Within the same isomers, even slight differences in lipophilicity significantly affect these levels.

\section{Outlook}

According to the poor biodegradability of PBDEs, questions concerning the accumulation of PBDEs in the food chain and inhalation exposure will continue to be relevant for future decades. Comparable problems as described for PBDEs could be expected for alternative brominated flame retardants such as hexabromobenzene, pentabromotoluene, 1,2-bis(2,4,6-tribromophenoxy)ethane, decabromodiphenylethane or dechloran plus, since they also exhibit a high degree of bromination, high persistence and a high bioaccumulation potential.
Acknowledgements We would like to thank Lukas Lesmeister (DVGW, Karlsruhe), Melanie Mechler (Center of Agricultural Technology Augustenberg, Karlsruhe) and Prof. Karl-Heinrich Engesser (ISWA, Stuttgart) for their continuous support.

Funding Open Access funding enabled and organized by Projekt DEAL. This work was supported by the German Federal Environment Agency [acronym FLUORTRANSFER, grant number FKZ 371874210 0; AZ: 91 007-2/82].

\section{Compliance with ethical standards}

Conflict of interest The authors declare that they have no conflict of interest.

Open Access This article is licensed under a Creative Commons Attribution 4.0 International License, which permits use, sharing, adaptation, distribution and reproduction in any medium or format, as long as you give appropriate credit to the original author(s) and the source, provide a link to the Creative Commons licence, and indicate if changes were made. The images or other third party material in this article are included in the article's Creative Commons licence, unless indicated otherwise in a credit line to the material. If material is not included in the article's Creative Commons licence and your intended use is not permitted by statutory regulation or exceeds the permitted use, you will need to obtain permission directly from the copyright holder. To view a copy of this licence, visit http://creativecommons.org/licenses/by/4.0/.

\section{References}

Amundsen CE, Paulsrud B, Linjordet R (2005) Organiske forurensninger i kompost og biorest. Delprojekt, vol 8

Binelli A, Sarkar SK, Chatterjee M, Riva C, Parolini M, Bhattacharya Bd, Bhattacharya AK, Satpathy KK (2007) Concentration of polybrominated diphenyl ethers (PBDEs) in sediment cores of Sundarban mangrove wetland, northeastern part of Bay of Bengal (India). Mar Pollut Bull 54:1220-1229. https://doi.org/10.1016/j.marpolbul.2007. 03.021

Bintein S, Devillers J, Karcher W (1993) Nonlinear dependence of fish bioconcentration on n-octanol/water partition coefficient. SAR QSAR Environ Res 1:29-39. https://doi. org/10.1080/10629369308028814

Brändli RC (2006) Organic pollutants in Swiss compost and digestate. Doctor thesis, EPFL

Briggs GG, Bromilow RH, Evans AA (1982) Relationships between lipophilicity and root uptake and translocation of non-ionised chemicals by barley. Pestic Sci 13:495-504. https://doi.org/10.1002/ps.2780130506

Brudzińska-Kosior A, Kosior G, Klánová J, Vaňková L, Kukučka P, Chropeňová M, Samecka-Cymerman A, Kolon K, Mróz L, Kempers AJ (2015) Polybrominated diphenyl ethers (PBDEs) in herbaceous Centaurium erythraea affected by various sources of environmental pollution. J Environ Sci Health A Tox Hazard Subst Environ Eng 
50:1369-1375. https://doi.org/10.1080/10934529.2015. 1064282

BSEF Bromine Science and Environmental Forum (2003) Major brominated flame retardants volume estimatestotal market demand by Region in 2001

Chai M, Li R, Shi C, Shen X, Li R, Zan Q (2019) Contamination of polybrominated diphenyl ethers (PBDEs) in urban mangroves of Southern China. Sci Total Environ 646:390-399. https://doi.org/10.1016/j.scitotenv.2018.07. 278

Chen J, Zhou HC, Wang C, Zhu CQ, Tam NF-Y (2015) Shortterm enhancement effect of nitrogen addition on microbial degradation and plant uptake of polybrominated diphenyl ethers (PBDEs) in contaminated mangrove soil. J Hazard Mater 300:84-92. https://doi.org/10.1016/j.jhazmat.2015. 06.053

Chen J, Wang C, Shen Z-J, Gao G-F, Zheng H-L (2017) Insight into the long-term effect of mangrove species on removal of polybrominated diphenyl ethers (PBDEs) from BDE-47 contaminated sediments. Sci Total Environ 575:390-399. https://doi.org/10.1016/j.scitotenv.2016.10.040

Chen F, Zeng S, Ma J, Li X, Zhang S, Zhu Q (2019) Interactions between decabromodiphenyl ether and lead in soil-plant system. Chemosphere 236:124406. https://doi.org/10. 1016/j.chemosphere.2019.124406

Chen Y, Zhang A, Li H, Peng Y, Lou X, Liu M, Hu J, Liu C, Wei B, Jin J (2020) Concentrations and distributions of polybrominated diphenyl ethers (PBDEs) in surface soils and tree bark in Inner Mongolia, northern China, and the risks posed to humans. Chemosphere 247:125950. https://doi. org/10.1016/j.chemosphere.2020.125950

Cheng Z, Wang Y, Wang S, Luo C, Li J, Chaemfa C, Jiang H, Zhang G (2014) The influence of land use on the concentration and vertical distribution of PBDEs in soils of an e-waste recycling region of South China. Environ Pollut 191:126-131. https://doi.org/10.1016/j.envpol.2014.04. 025

Chow KL, Man YB, Tam NFY, Liang Y, Wong MH (2015) Uptake and transport mechanisms of decabromodiphenyl ether (BDE-209) by rice (Oryza sativa). Chemosphere 119:1262-1267. https://doi.org/10.1016/j.chemosphere. 2014.10.016

Chow KL, Man YB, Tam NFY, Liang Y, Wong MH (2017) Removal of decabromodiphenyl ether (BDE-209) using a combined system involving $\mathrm{TiO} 2$ photocatalysis and wetland plants. J Hazard Mater 322:263-269. https://doi.org/ 10.1016/j.jhazmat.2016.05.097

Collins CD, Finnegan E (2010) Modeling the plant uptake of organic chemicals, including the soil-air-plant pathway. Environ Sci Technol 44:998-1003. https://doi.org/10. 1021/es901941z

Corsolini S, Baroni D, Martellini T, Pala N, Cincinelli A (2019) PBDEs and PCBs in terrestrial ecosystems of the Victoria Land, Antarctica. Chemosphere 231:233-239. https://doi. org/10.1016/j.chemosphere.2019.05.126

Demirtepe H, Imamoglu I (2019) Levels of polybrominated diphenyl ethers and hexabromocyclododecane in treatment plant sludge: implications on sludge management. Chemosphere 221:606-615. https://doi.org/10.1016/j. chemosphere.2019.01.060
Deng D, Liu J, Xu M, Zheng G, Guo J, Sun G (2016) Uptake, translocation and metabolism of decabromodiphenyl ether (BDE-209) in seven aquatic plants. Chemosphere 152:360-368. https://doi.org/10.1016/j.chemosphere. 2016.03.013

Ding C, Chang W-J, Zeng H, Ni H-G (2014) Field and modeling study of PBDEs uptake by three tree species. Sci Total Environ 472:923-928. https://doi.org/10.1016/j.scitotenv. 2013.11.141

Dreyer A, Neugebauer F, Rüdel H, Klein R, Lohmann N, Rauert C, Koschorreck J (2018) Halogenated flame retardants in tree samples applied as bioindicators for atmospheric pollution. Chemosphere 208:233-240. https://doi.org/10. 1016/j.chemosphere.2018.05.033

ECHA European Chemicals Agency (2015) Background document to the Opinion on the Annex XV dossier proposing restrictions on Bis(pentabromophenyl)ether: ECHA/RAC/ RES-O-0000006155-77-01/D ECHA/SEAC/RES-O0000006155-77-03/F, EC-Number 214-604-9, Helsinki

Eggerstedt-Lehmann F (2005) Einsatz von mykorrhizierten Pflanzen in der Phytoremediation und ihr Einfluss auf Selbstreinigungsprozesse (enhanced natural attenuation) in MKW-belasteten Böden. Dissertation, Universität Bremen

European Chemicals Bureau ECB (2003) European Union Risk Assessment Report: Diphenyl ether, ocatabromo deriv. EUR 20403 EN. 1st Priority List, vol 16, Luxembourg

European Commission EC (2017) EC Regulation 217/227 amending Annex XVII to Regulation (EC) No 1907/2006 of the European Parliament and of the Council concerning the Registration, Evaluation, Authorisation and Restriction of Chemicals (REACH) as regards bis(pentabromophenyl)ether

European Food Safety Authority EFSA (2011) Scientific opinion on polybrominated diphenyl ethers (PBDEs) in food. EFSA J 9:2156. https://doi.org/10.2903/j.efsa.2011.2156

Fan Y, Chen S-J, Li Q-Q, Zeng Y, Yan X, Mai B-X (2020) Uptake of halogenated organic compounds (HOCs) into peanut and corn during the whole life cycle grown in an agricultural field. Environ Pollut 263:114400. https://doi. org/10.1016/j.envpol.2020.114400

Farzana S, Chen J, Pan Y, Wong Y-S, Tam NFY (2017) Antioxidative response of Kandelia obovata, a true mangrove species, to polybrominated diphenyl ethers (BDE-99 and BDE-209) during germination and early growth. Mar Pollut Bull 124:1063-1070. https://doi.org/10.1016/j. marpolbul.2016.12.041

Farzana S, Zhou H, Cheung SG, Tam NFY (2019a) Could mangrove plants tolerate and remove BDE-209 in contaminated sediments upon long-term exposure? J Hazard Mater 378:120731. https://doi.org/10.1016/j.jhazmat. 2019.06.008

Farzana S, Cheung SG, Tam NFY (2019b) Effects of aquaculture effluents on fate of 2,2',4,4',5-pentabromodiphenyl ether (BDE-99) in contaminated mangrove sediment planted with Kandelia obovata. Sci Total Environ 691:71-79. https://doi.org/10.1016/j.scitotenv.2019.07. 057

Feng J, Shen X, Chen J, Shi J, Xu J, Tang C, Brookes PC, He Y (2019) Improved rhizoremediation for decabromodiphenyl ether (BDE-209) in E-waste contaminated soils. Soil Ecol 
Lett 1:157-173. https://doi.org/10.1007/s42832-019-00079

Fraser AJ, Webster TF, McClean MD (2009) Diet contributes significantly to the body burden of PBDEs in the general U.S. population. Environ Health Perspect 117:1520-1525. https://doi.org/10.1289/ehp.0900817

Freudenschuß A, Erik O, Maria U (2008) Organische Schadstoffe in Grünlandböden, REP-0158. Umweltbundesamt $\mathrm{GmbH}$, Wien

Freudenschuß A, Erik O, Maria U (2010) Organische Schadstoffe in Grünlandböden: TEIL 3-Endbericht, REP-0268. Umweltbundesamt GmbH, Wien

Gao M, Wang G, Lin B, Tariq M, Liu K, Zhang W (2019) Study on arbor leaf and ring as a potential biological indicator for atmospheric polybrominated diphenyl ethers (PBDEs) distribution at e-wastes recycling sites. Int J Environ Sci Technol 16:8639-8652. https://doi.org/10.1007/s13762019-02428-x

Gottschall N, Topp E, Edwards M, Payne M, Kleywegt S, Lapen DR (2017) Brominated flame retardants and perfluoroalkyl acids in groundwater, tile drainage, soil, and crop grain following a high application of municipal biosolids to a field. Sci Total Environ 574:1345-1359. https://doi.org/10. 1016/j.scitotenv.2016.08.044

Graziani NS, Tames MF, Mateos AC, Silva JA, Ramos S, Homem V, Ratola N, Carreras H (2019) Estimation of urban POP and emerging SVOC levels employing Ligustrum lucidum leaves. Atmos Pollut Res 10:1524-1530. https://doi.org/10.1016/j.apr.2019.04.010

Hale RC, La Guardia MJ, Harvey E, Chen D, Mainor TM, Luellen DR, Hundal LS (2012) Polybrominated diphenyl ethers in U.S. sewage sludges and biosolids: temporal and geographical trends and uptake by corn following land application. Environ Sci Technol 46:2055-2063. https:// doi.org/10.1021/es203149g

Han Z-X, Wang N, Zhang H-L, Zhao Y-X (2017) Bioaccumulation of PBDEs and PCBs in a small food chain at electronic waste recycling sites. Environ Forensics 18:44-49. https://doi.org/10.1080/15275922.2016.1263900

Harrad S, Goosey E, Desborough J, Abdallah MA-E, Roosens L, Covaci A (2010) Dust from U.K. primary school classrooms and daycare centers: the significance of dust as a pathway of exposure of young U.K. children to brominated flame retardants and polychlorinated biphenyls. Environ Sci Technol 44:4198-4202. https://doi.org/10.1021/ es100750s

Hassanin A, Breivik K, Meijer SN, Steinnes E, Thomas GO, Jones KC (2004) PBDEs in European background soils: levels and factors controlling their distribution. Environ Sci Technol 38:738-745. https://doi.org/10.1021/es035008y

He Y, Li X, Shen X, Jiang Q, Chen J, Shi J, Tang X, Xu J (2015) Plant-assisted rhizoremediation of decabromodiphenyl ether for e-waste recycling area soil of Taizhou, China. Environ Sci Pollut Res 22:9976-9988. https://doi.org/10. 1007/s11356-015-4179-2

Hites RA (2004) Polybrominated diphenyl ethers in the environment and in people: a meta-analysis of concentrations. Environ Sci Technol 38:945-956. https://doi.org/10.1021/ es035082g

Hu Y, Sun Y, Pei N, Zhang Z, Li H, Wang W, Xie J, Xu X, Luo X, Mai B (2020) Polybrominated diphenyl ethers and alternative halogenated flame retardants in mangrove plants from Futian National Nature Reserve of Shenzhen City, South China. Environ Pollut 260:114087. https://doi. org/10.1016/j.envpol.2020.114087

Huang H, Zhang S, Christie P, Wang S, Xie M (2010) Behavior of decabromodiphenyl ether (BDE-209) in the soil-plant system: uptake, translocation, and metabolism in plants and dissipation in soil. Environ Sci Technol 44:663-667. https://doi.org/10.1021/es901860r

Huang H, Zhang S, Christie P (2011) Plant uptake and dissipation of PBDEs in the soils of electronic waste recycling sites. Environ Pollut 159:238-243. https://doi.org/10.1016/ j.envpol.2010.08.034

Hwang J-I, Lee S-E, Kim J-E (2017) Comparison of theoretical and experimental values for plant uptake of pesticide from soil. PLoS ONE 12:e0172254. https://doi.org/10.1371/ journal.pone.0172254

Jia W, Ma C, White JC, Yin M, Cao H, Wang J, Wang C, Sun H, Xing B (2019) Effects of biochar on 2, 2', 4, 4', 5, 5' hexabrominated diphenyl ether (BDE-153) fate in Amaranthus mangostanus L.: accumulation, metabolite formation, and physiological response. Sci Total Environ 651:1154-1165. https://doi.org/10.1016/j.scitotenv.2018. 09.229

Jian K, Zhao L, Ya M, Zhang Y, Su H, Meng W, Li J, Su G (2020) Dietary intake of legacy and emerging halogenated flame retardants using food market basket estimations in Nanjing, eastern China. Environ Pollut 258:113737. https://doi.org/10.1016/j.envpol.2019.113737

Johnson-Restrepo B, Kannan K (2009) An assessment of sources and pathways of human exposure to polybrominated diphenyl ethers in the United States. Chemosphere 76:542-548. https://doi.org/10.1016/j.chemosphere.2009. 02.068

Klinčić D, Dvoršćak M, Jagić K, Mendaš G, Herceg Romanić S (2020) Levels and distribution of polybrominated diphenyl ethers in humans and environmental compartments: a comprehensive review of the last five years of research. Environ Sci Pollut Res 27:5744-5758. https://doi.org/10. 1007/s11356-020-07598-7

Kosior G, Klánová J, Vaňková L, Kukučka P, Chropeňová M, Brudzińska-Kosior A, Samecka-Cymerman A, Kolon K, Kempers AJ (2015) Pleurozium schreberi as an ecological indicator of polybrominated diphenyl ethers (PBDEs) in a heavily industrialized urban area. Ecol Ind 48:492-497. https://doi.org/10.1016/j.ecolind.2014.09.003

Kosior G, Přibylová P, Vaňková L, Kukučka P, Audy O, Klánová J, Samecka-Cymerman A, Mróz L, Kempers AJ (2017) Bioindication of PBDEs and PCBs by native and transplanted moss Pleurozium schreberi. Ecotoxicol Environ Saf 143:136-142. https://doi.org/10.1016/j. ecoenv.2017.05.025

Kuch B, Körner W, Hagenmaier H (2001) Monitoring von bromierten Flammschutzmitteln in Fließgewässern, Abwässern und Klärschlamm in Baden-Württemberg: Abschlussbericht FZKA-BWPLUS. Landesanstalt für Umwelt Baden-Württemberg (LUBW), Karlsruhe

Kuch B, Schneider C, Rupp S, Recke Rvd, Bopp K, Metzger JW (2005) Polybromierte Diphenylether und Tetrabrombisphenol A: Untersuchungen zum Abbau und Metabolismus, Bestimmung in Nahrungsmitteln: Abschlussbericht 
BWPLUS. Landesanstalt für Umwelt Baden-Württemberg (LUBW), Karlsruhe

Kuch B, Rupp S, Fischer K, Kranert M, Metzger JW (2007) Untersuchungen von Komposten und Gärsubstraten auf organische Schadstoffe in Baden-Württemberg: Abschlussbericht. Landesanstalt für Umwelt BadenWürttemberg (LUBW), Karlsruhe

Law RJ, Allchin CR, de Boer J, Covaci A, Herzke D, Lepom P, Morris S, Tronczynski J, de Wit CA (2006) Levels and trends of brominated flame retardants in the European environment. Chemosphere 64:187-208. https://doi.org/ 10.1016/j.chemosphere.2005.12.007

Law RJ, Losada S, Barber JL, Bersuder P, Deaville R, Brownlow A, Penrose R, Jepson PD (2013) Alternative flame retardants, Dechlorane Plus and BDEs in the blubber of harbour porpoises (Phocoena phocoena) stranded or by caught in the UK during 2008. Environ Int 60:81-88. https://doi.org/10.1016/j.envint.2013.08.009

Leisewitz A, Fengler S, Seel P (2003) Orientierende Messungen gefährlicher Stoffe: Landesweite Untersuchung auf organische Spurenverunreinigungen in hessischen Fließgewässern, Abwässern und Klärschlämmmen.: Zusammenfassender Abschlussbericht 1991-2003. Hessisches Landesamt für Umwelt und Geologie (HLUG), Wiesbaden

Leung AOW, Luksemburg WJ, Wong AS, Wong MH (2007) Spatial distribution of polybrominated diphenyl ethers and polychlorinated dibenzo- $p$-dioxins and dibenzofurans in soil and combusted residue at Guiyu, an electronic waste recycling site in southeast China. Environ Sci Technol 41:2730-2737. https://doi.org/10.1021/es0625935

Li P, Wu H, Li Q, Jin J, Wang Y (2015a) Brominated flame retardants in food and environmental samples from a production area in China: concentrations and human exposure assessment. Environ Monit Assess 187:719. https://doi. org/10.1007/s10661-015-4947-y

Li H, Qu R, Yan L, Guo W, Ma Y (2015b) Field study on the uptake and translocation of PBDEs by wheat (Triticum aestivum L.) in soils amended with sewage sludge. Chemosphere 123:87-92. https://doi.org/10.1016/j. chemosphere.2014.12.045

Li X, Chen AY, Wu Y, Wu L, Xiang L, Zhao HM, Cai QY, Li YW, Mo CH, Wong MH, Li H (2018a) Applying $\beta$-cyclodextrin to amaranth inoculated with white-rot fungus for more efficient remediation of soil co-contaminated with $\mathrm{Cd}$ and BDE-209. Sci Total Environ 634:417-426. https://doi. org/10.1016/j.scitotenv.2018.03.310

Li H, Li X, Xiang L, Zhao HM, Li YW, Cai QY, Zhu L, Mo CH, Wong MH (2018b) Phytoremediation of soil co-contaminated with $\mathrm{Cd}$ and BDE-209 using hyperaccumulator enhanced by AM fungi and surfactant. Sci Total Environ 613-614:447-455. https://doi.org/10.1016/j.scitotenv. 2017.09.066

Li X, Chen AY, Le Yu Y, Chen XX, Xiang L, Zhao HM, Mo CH, Li YW, Cai QY, Wong MH, Li H (2019a) Effects of $\beta$ cyclodextrin on phytoremediation of soil co-contaminated with Cd and BDE-209 by arbuscular mycorrhizal amaranth. Chemosphere 220:910-920. https://doi.org/10.1016/ j.chemosphere.2018.12.211

Li Y, Chiou CT, Li H, Schnoor JL (2019b) Improved prediction of the bioconcentration factors of organic contaminants from soils into plant/crop roots by related physicochemical parameters. Environ Int 126:46-53. https://doi.org/10. 1016/j.envint.2019.02.020

Li H, Shao F, Qiu Y, Ma Y (2019c) Solubility, uptake, and translocation of BDE 47 as affected by DOM extracted from agricultural wastes. Environ Sci Pollut Res 26:19871-19878. https://doi.org/10.1007/s11356-01905393-7

Li H, Huang WX, Gao MY, Li X, Xiang L, Mo CH, Li YW, Cai QY, Wong MH, Wu FY (2020a) AM fungi increase uptake of Cd and BDE-209 and activities of dismutase and catalase in amaranth (Amaranthus hypochondriacus L.) in two contaminants spiked soil. Ecotoxicol Environ Saf 195:110485. https://doi.org/10.1016/j.ecoenv.2020. 110485

Li R, Ding H, Guo M, Shen X, Zan Q (2020b) Do pyrene and Kandelia obovata improve removal of BDE-209 in mangrove soils? Chemosphere 240:124873. https://doi.org/10. 1016/j.chemosphere.2019.124873

Liagkouridis I, Cousins AP, Cousins IT (2015) Physicalchemical properties and evaluative fate modelling of "emerging" and "novel" brominated and organophosphorus flame retardants in the indoor and outdoor environment. Sci Total Environ 524-525:416-426. https://doi. org/10.1016/j.scitotenv.2015.02.106

Lorber M (2008) Exposure of Americans to polybrominated diphenyl ethers. J Expo Sci Environ Epidemiol 18:2-19. https://doi.org/10.1038/sj.jes.7500572

Lu M, Zhang Z-Z (2014) Phytoremediation of soil co-contaminated with heavy metals and deca-BDE by co-planting of Sedum alfredii with tall fescue associated with Bacillus cereus JP12. Plant Soil 382:89-102. https://doi.org/10. 1007/s11104-014-2147-0

Lu M, Zhang Z-Z, Su X-L, Xu Y-X, Wu X-J, Zhang M (2013) Effect of copper on in vivo fate of BDE-209 in pumpkin. J Hazard Mater 262:311-317. https://doi.org/10.1016/j. jhazmat.2013.08.067

Ma J, Addink R, Yun S, Cheng J, Wang W, Kannan K (2009) Polybrominated dibenzo-p-dioxins/ dibenzofurans and polybrominated diphenyl ethers in soil, vegetation, workshop-floor dust, and electronic shredder residue from an electronic waste recycling facility and in soils from a chemical industrial complex in eastern China. Environ Sci Technol 43:7350-7356. https://doi.org/10.1021/ es901713u

Ma J, Zhang Q, Chen F, Zhu Q, Wang Y, Liu G (2020) Remediation of PBDEs-metal co-contaminated soil by the combination of metal stabilization, persulfate oxidation and bioremediation. Chemosphere 252:126538. https://doi. org/10.1016/j.chemosphere.2020.126538

Marb C, Scheithauer M, Bittl T, Köhler R, Veit N (2003) Kompostierung von Bioabfällen mit anderen organischen Abfällen: Abschlussbericht. Bayerisches Landesamt für Umweltschutz, Augsburg

Martellini T, Diletti G, Scortichini G, Lolini M, Lanciotti E, Katsoyiannis A, Cincinelli A (2016) Occurrence of polybrominated diphenyl ethers (PBDEs) in foodstuffs in Italy and implications for human exposure. Food Chem Toxicol 89:32-38. https://doi.org/10.1016/j.fct.2015.12.026

Meylan WM, Howard PH, Boethling RS, Aronson D, Printup H, Gouchie S (1999) Improved method for estimating 
bioconcentration/bioaccumulation factor from octanol/ water partition coefficient. Environ Toxicol Chem 18:664-672. https://doi.org/10.1002/etc.5620180412

Mueller KE, Mueller-Spitz SR, Henry HF, Vonderheide AP, Soman RS, Kinkle BK, Shann JR (2006) Fate of pentabrominated diphenyl ethers in soil: abiotic sorption, plant uptake, and the impact of interspecific plant interactions. Environ Sci Technol 40:6662-6667. https://doi.org/ 10.1021/es0607761

Muenhor D, Harrad S, Ali N, Covaci A (2010) Brominated flame retardants (BFRs) in air and dust from electronic waste storage facilities in Thailand. Environ Int 36:690-698. https://doi.org/10.1016/j.envint.2010.05.002

Navarro I, de La Torre A, Sanz P, Porcel MÁ, Pro J, Carbonell G, de Martínez MLÁ (2017) Uptake of perfluoroalkyl substances and halogenated flame retardants by crop plants grown in biosolids-amended soils. Environ Res 152:199-206. https://doi.org/10.1016/j.envres.2016.10. 018

Nendza M (1991) QSARs of bioconcentration-validity assessment of $\log \mathrm{P} / \log \mathrm{BCF}$ correlations. Bioaccumulation in aquatic systems. VCH, Weinheim

Pan L, Sun J, Wu X, Wei Z, Zhu L (2016) Transformation of hydroxylated and methoxylated 2,2',4,4',5-brominated diphenyl ether (BDE-99) in plants. J Environ Sci 49:197-202. https://doi.org/10.1016/j.jes.2016.06.017

Pan Y, Chen J, Zhou H, Cheung SG, Tam NFY (2020) Degradation of BDE-47 in mangrove sediments with amendment of extra carbon sources. Mar Pollut Bull 153:110972. https://doi.org/10.1016/j.marpolbul.2020.110972

Pi N, Wu Y, Zhu HW, Wong YS, Tam NFY (2017) The uptake of mixed PAHs and PBDEs in wastewater by mangrove plants under different tidal flushing regimes. Environ Pollut 231:104-114. https://doi.org/10.1016/j.envpol. 2017.07.085

Pier MD, Zeeb BA, Reimer KJ (2002) Patterns of contamination among vascular plants exposed to local sources of polychlorinated biphenyls in the Canadian Arctic and Subarctic. Sci Total Environ 297:215-227. https://doi.org/10. 1016/S0048-9697(02)00134-1

Pimviriyakul P, Wongnate T, Tinikul R, Chaiyen P (2020) Microbial degradation of halogenated aromatics: molecular mechanisms and enzymatic reactions. Microb Biotechnol 13:67-86. https://doi.org/10.1111/1751-7915. 13488

Qiu Y-W, Qiu H-L, Zhang G, Li J (2019) Bioaccumulation and cycling of polybrominated diphenyl ethers (PBDEs) and dechlorane plus (DP) in three natural mangrove ecosystems of South China. Sci Total Environ 651:1788-1795. https:// doi.org/10.1016/j.scitotenv.2018.10.055

Reineke W, Mars AE, Kaschabek SR, Janssen DB (2002) Microbial degradation of chlorinated aromatic compounds. In: Agathos SN, Reineke W (eds) Biotechnology for the environment: strategy and fundamentals, 3A. Springer, Dordrecht, pp 157-168

Salamova A, Hites RA (2010) Evaluation of tree bark as a passive atmospheric sampler for flame retardants, PCBs, and organochlorine pesticides. Environ Sci Technol 44:6196-6201. https://doi.org/10.1021/es101599h

Salamova A, Hites RA (2013) Brominated and chlorinated flame retardants in tree bark from around the globe.
Environ Sci Technol 47:349-354. https://doi.org/10.1021/ es303393z

Schecter A, Päpke O, Harris TR, Tung KC, Musumba A, Olson J, Birnbaum L (2006) Polybrominated diphenyl ether (PBDE) levels in an expanded market basket survey of U.S. food and estimated PBDE dietary intake by age and sex. Environ Health Perspect 114:1515-1520. https://doi.org/ 10.1289/ehp.9121

Schreder ED, La Guardia MJ (2014) Flame retardant transfers from U.S. households (dust and laundry wastewater) to the aquatic environment. Environ Sci Technol 48:11575-11583. https://doi.org/10.1021/es502227h

Sellström U, de Wit CA, Lundgren N, Tysklind M (2005) Effect of sewage-sludge application on concentrations of higherbrominated diphenyl ethers in soils and earthworms. Environ Sci Technol 39:9064-9070. https://doi.org/10. 1021/es051190m

She Y-Z, Wu J-P, Zhang Y, Peng Y, Mo L, Luo X-J, Mai B-X (2013) Bioaccumulation of polybrominated diphenyl ethers and several alternative halogenated flame retardants in a small herbivorous food chain. Environ Pollut 174:164-170. https://doi.org/10.1016/j.envpol.2012.11. 024

Sjödin A, Carlsson H, Thuresson K, Sjölin S, Bergman A, Ostman C (2001) Flame retardants in indoor air at an electronics recycling plant and at other work environments. Environ Sci Technol 35:448-454. https://doi.org/10.1021/ es000077n

Stapleton HM, Kelly SM, Allen JG, McClean MD, Webster TF (2008) Measurement of polybrominated diphenyl ethers on hand wipes: estimating exposure from hand-to-mouth contact. Environ Sci Technol 42:3329-3334. https://doi. org/10.1021/es7029625

Stone R (2009) China. Confronting a toxic blowback from the electronics trade. Science 325:1055. https://doi.org/10. 1126/science.325_1055

Sun Y, Wang C, Xu X, Ruan H (2020) Responses of plants to polybrominated diphenyl ethers (PBDEs) induced phytotoxicity: a hierarchical meta-analysis. Chemosphere 240:124865. https://doi.org/10.1016/j.chemosphere.2019. 124865

Száková J, Pulkrabová J, Černý J, Mercl F, Švarcová A, Gramblička T, Najmanová J, Tlustoš P, Balík J (2019) Selected persistent organic pollutants (POPs) in the rhizosphere of sewage sludge-treated soil: implications for the biodegradability of POPs. Arch Agron Soil Sci 65:994-1009. https://doi.org/10.1080/03650340.2018. 1543945

Tao F, Abdallah MA-E, Harrad S (2016) Emerging and legacy flame retardants in UK indoor air and dust: evidence for replacement of PBDEs by emerging flame retardants? Environ Sci Technol 50:13052-13061. https://doi.org/10. 1021/acs.est.6b02816

Teuten EL, Rowland SJ, Galloway TS, Thompson RC (2007) Potential for plastics to transport hydrophobic contaminants. Environ Sci Technol 41:7759-7764. https://doi.org/ $10.1021 / \mathrm{es} 071737 \mathrm{~s}$

Tian M, Chen S-J, Wang J, Luo Y, Luo X-J, Mai B-X (2012) Plant uptake of atmospheric brominated flame retardants at an E-waste site in southern China. Environ Sci Technol 46:2708-2714. https://doi.org/10.1021/es203669n 
Ueno D, Darling C, Alaee M, Pacepavicius G, Teixeira C, Campbell L, Letcher RJ, Bergman A, Marsh G, Muir D (2008) Hydroxylated polybrominated diphenyl ethers (OH-PBDEs) in the abiotic environment: surface water and precipitation from Ontario, Canada. Environ Sci Technol 42:1657-1664. https://doi.org/10.1021/es7021279

Venkatesan AK, Halden RU (2014) Brominated flame retardants in U.S. biosolids from the EPA national sewage sludge survey and chemical persistence in outdoor soil mesocosms. Water Res 55:133-142. https://doi.org/10. 1016/j.watres.2014.02.021

Vitali M, Antonucci A, Owczarek M, Guidotti M, Astolfi ML, Manigrasso M, Avino P, Bhattacharya B, Protano C (2019) Air quality assessment in different environmental scenarios by the determination of typical heavy metals and Persistent Organic Pollutants in native lichen Xanthoria parietina. Environ Pollut 254:113013. https://doi.org/10.1016/j. envpol.2019.113013

Vrkoslavová J, Demnerová K, Macková M, Zemanová T, Macek T, Hajslová J, Pulkrabová J, Hrádková P, Stiborová $\mathrm{H}$ (2010) Absorption and translocation of polybrominated diphenyl ethers (PBDEs) by plants from contaminated sewage sludge. Chemosphere 81:381-386. https://doi.org/ 10.1016/j.chemosphere.2010.07.010

Wang J, Ma Y-J, Chen S-J, Tian M, Luo X-J, Mai B-X (2010) Brominated flame retardants in house dust from e-waste recycling and urban areas in South China: implications on human exposure. Environ Int 36:535-541. https://doi.org/ 10.1016/j.envint.2010.04.005

Wang S, Zhang S, Huang H, Christie P (2011a) Behavior of decabromodiphenyl ether (BDE-209) in soil: effects of rhizosphere and mycorrhizal colonization of ryegrass roots. Environ Pollut 159:749-753. https://doi.org/10. 1016/j.envpol.2010.11.035

Wang Y, Luo C, Li J, Yin H, Li X, Zhang G (2011b) Characterization of PBDEs in soils and vegetations near an e-waste recycling site in South China. Environ Pollut 159:2443-2448. https://doi.org/10.1016/j.envpol.2011.06. 030

Wang S, Zhang S, Huang H, Zhao M, Lv J (2011c) Uptake, translocation and metabolism of polybrominated diphenyl ethers (PBDEs) and polychlorinated biphenyls (PCBs) in maize (Zea mays L.). Chemosphere 85:379-385. https:// doi.org/10.1016/j.chemosphere.2011.07.002

Wang S, Zhang S, Huang H, Lu A, Ping H (2012) Debrominated, hydroxylated and methoxylated metabolism in maize (Zea mays L.) exposed to lesser polybrominated diphenyl ethers (PBDEs). Chemosphere 89:1295-1301. https://doi.org/10.1016/j.chemosphere.2012.05.026

Wang Y, Luo C, Li J, Yin H, Zhang G (2014) Influence of plants on the distribution and composition of PBDEs in soils of an e-waste dismantling area: evidence of the effect of the rhizosphere and selective bioaccumulation. Environ Pollut 186:104-109. https://doi.org/10.1016/j.envpol.2013.11. 018

Wang J, Liu L, Wang J, Pan B, Fu X, Zhang G, Zhang L, Lin K (2015) Distribution of metals and brominated flame retardants (BFRs) in sediments, soils and plants from an informal e-waste dismantling site, South China. Environ Sci Pollut Res Int 22:1020-1033. https://doi.org/10.1007/ s11356-014-3399-1
Wang S, Wang Y, Song M, Luo C, Li J, Zhang G (2016a) Distributions and compositions of old and emerging flame retardants in the rhizosphere and non-rhizosphere soil in an e-waste contaminated area of South China. Environ Pollut 208:619-625. https://doi.org/10.1016/j.envpol.2015.10. 038

Wang S, Wang Y, Luo C, Li J, Yin H, Zhang G (2016b) Plant selective uptake of halogenated flame retardants at an e-waste recycling site in southern China. Environ Pollut 214:705-712. https://doi.org/10.1016/j.envpol.2016.04. 071

Wang C, Ma C, Jia W, Wang D, Sun H, Xing B (2017) Combined effects of dissolved humic acids and tourmaline on the accumulation of 2, 2', 4, 4', 5, 5'- hexabrominated diphenyl ether (BDE-153) in Lactuca sativa. Environ Pollut 231:68-77. https://doi.org/10.1016/j.envpol.2017. 07.094

Wang J, Huang T, Tao X, Li H, Duan X, Zou M, Lu G (2019) Rapid biodegradation of 2,2',4,4'-tetrabromodiphenyl ether (BDE-47) by Achromobacter xylosoxidans GYP4. DWT 162:353-363. https://doi.org/10.5004/dwt.2019. 24353

Wang M, Yang Y, Shen C, Li X, Shen D, Shentu J (2019) Tranformation of decabromodiphenyl ether (BDE-209) in a soil-Sedum Alfredii system and the effect on soil enzyme and acyl-homoserine lactones. Fresenius Environ Bull 28:9140-9151

Wang G, Liu Y, Tao W, Zhao X, Wang H, Lou Y, Li N, Liu Y (2020) Assessing microbial degradation degree and bioavailability of BDE-153 in natural wetland soils: Implication by compound-specific stable isotope analysis. Environ Pollut 260:114014. https://doi.org/10.1016/j. envpol.2020.114014

Wen Z, Chen M, Lu H, Huang S, Xing J, Hong L, Chen Y (2019) Distributions and compositions of brominated diphenyl ethers-209 in pine seedlings inoculated with ectomycorrhizal fungi. Water Air Soil Pollut. https://doi.org/10.1007/ s11270-019-4338-z

Wu N, Herrmann T, Paepke O, Tickner J, Hale R, Harvey LE, La Guardia M, McClean MD, Webster TF (2007) Human exposure to PBDEs: associations of PBDE body burdens with food consumption and house dust concentrations. Environ Sci Technol 41:1584-1589. https://doi.org/10. 1021/es0620282

Wu J, Yi Y, Fang Z, Tsang EP (2018) Effects of biochar on phytotoxicity and translocation of polybrominated diphenyl ethers in $\mathrm{Ni} / \mathrm{Fe}$ bimetallic nanoparticle-treated soil. Environ Sci Pollut Res Int 25:2570-2579. https://doi.org/ 10.1007/s11356-017-0627-5

Wu X, Wang W, Zhu L (2018) Enhanced organic contaminants accumulation in crops: mechanisms, interactions with engineered nanomaterials in soil. Environ Pollut 240:51-59. https://doi.org/10.1016/j.envpol.2018.04.072

Wu Q, Leung JYS, Du Y, Kong D, Shi Y, Wang Y, Xiao T (2019) Trace metals in e-waste lead to serious health risk through consumption of rice growing near an abandoned e-waste recycling site: Comparisons with PBDEs and AHFRs. Environ Pollut 247:46-54. https://doi.org/10. 1016/j.envpol.2018.12.051

Xiang L, Song Y, Bian Y, Liu G, Herzberger A, Gu C, Jiang X, Wang F (2018) Manure amendment reduced plant uptake 
and enhanced rhizodegradation of $2,2^{\prime}, 4,4^{\prime}$-tetrabrominated diphenyl ether in soil. Biol Fertil Soils 54:807-817. https://doi.org/10.1007/s00374-018-1304-7

Xiang L, Sheng H, Gu C, Marc R-G, Wang Y, Bian Y, Jiang X, Wang F (2019a) Biochar combined with compost to reduce the mobility, bioavailability and plant uptake of $2,2^{\prime}, 4,4^{\prime}$ tetrabrominated diphenyl ether in soil. J Hazard Mater 374:341-348. https://doi.org/10.1016/j.jhazmat.2019.04. 048

Xiang L, Sheng H, Xu M, Redmile-Gordon M, Bian Y, Yang X, Jiang X, Wang F (2019b) Reducing plant uptake of a brominated contaminant $\left(2,2^{\prime}, 4,4^{\prime}\right.$-tetrabrominated diphenyl ether) by incorporation of maize straw into horticultural soil. Sci Total Environ 663:29-37. https://doi.org/10.1016/ j.scitotenv.2019.01.297

Xu X, Wen B, Huang H, Wang S, Han R, Zhang S (2016) Uptake, translocation and biotransformation kinetics of BDE-47, 6-OH-BDE-47 and 6-MeO-BDE-47 in maize (Zea mays L.). Environ Pollut 208:714-722. https://doi. org/10.1016/j.envpol.2015.10.051

Xu J, Qian W, Li J, Zhang X, He J, Kong D (2019) Polybrominated diphenyl ethers (PBDEs) in soil and dust from plastic production and surrounding areas in eastern of China. Environ Geochem Health 41:2315-2327. https:// doi.org/10.1007/s10653-019-00247-0

Yan Y, Ma M, Zhang W, Ma W, Li M, Yan L (2017) Effect of elevated nitrate on biodegradation of pentabromodiphenyl ether (BDE-99) and change in microbial communities during groundwater recharge with tertiary-treated municipal wastewater. Int Biodeterior Biodegrad 124:128-137. https://doi.org/10.1016/j.ibiod.2017.03.022

Yang C-Y, Chang M-L, Wu SC, Shih Y-H (2017) Partition uptake of a brominated diphenyl ether by the edible plant root of white radish (Raphanus sativus L.). Environ Pollut 223:178-184. https://doi.org/10.1016/j.envpol.2017.01. 009

Yang C-Y, Wu SC, Lee C-C, Shih Y-H (2018) Translocation of polybrominated diphenyl ethers from field-contaminated soils to an edible plant. J Hazard Mater 351:215-223. https://doi.org/10.1016/j.jhazmat.2018.02.037

Yang NJ, Hinner MJ (2015) Getting across the cell membrane: an overview for small molecules, peptides, and proteins. Methods Mol Biol 1266:29-53. https://doi.org/10.1007/ 978-1-4939-2272-7_3

Yang ZZ, Zhao XR, Zhao Q, Qin ZF, Qin XF, Xu XB, Jin ZX, Xu CX (2008) Polybrominated diphenyl ethers in leaves and soil from typical electronic waste polluted area in South China. Bull Environ Contam Toxicol 80:340-344. https://doi.org/10.1007/s00128-008-9385-X

Yao Y, Wang B, He Y, Wang L, Corvini PF-X, Ji R (2020) Fate of 4-bromodiphenyl ether (BDE3) in soil and the effects of co-existed copper. Environ Pollut 261:114214. https://doi. org/10.1016/j.envpol.2020.114214

Yogui GT, Sericano JL, Montone RC (2011) Accumulation of semivolatile organic compounds in Antarctic vegetation: a case study of polybrominated diphenyl ethers. Sci Total Environ 409:3902-3908. https://doi.org/10.1016/j. scitotenv.2011.06.010

Yu Y, Yin H, Peng H, Lu G, Dang Z (2020) Proteomic mechanism of decabromodiphenyl ether (BDE-209) biodegradation by Microbacterium $\mathrm{Y} 2$ and its potential in remediation of BDE-209 contaminated water-sediment system. J Hazard Mater 387:121708. https://doi.org/10. 1016/j.jhazmat.2019.121708

Zhan L, Lin T, Cheng H, Wang Z, Cheng Z, Zhou D, Qin Z, Zhang G (2019) Atmospheric deposition and air-soil exchange of polybrominated diphenyl ethers (PBDEs) in a background site in Central China. Environ Sci Pollut Res 26:31934-31944. https://doi.org/10.1007/s11356-01906312-6

Zhang Y, Luo X-J, Mo L, Wu J-P, Mai B-X, Peng Y-H (2015) Bioaccumulation and translocation of polyhalogenated compounds in rice (Oryza sativa L.) planted in paddy soil collected from an electronic waste recycling site. South China Chemosphere 137:25-32. https://doi.org/10.1016/j. chemosphere.2015.04.029

Zhao Y-X, Qin X-F, Li Y, Liu P-Y, Tian M, Yan S-S, Qin Z-F, $\mathrm{Xu}$ X-B, Yang Y-J (2009) Diffusion of polybrominated diphenyl ether (PBDE) from an e-waste recycling area to the surrounding regions in Southeast China. Chemosphere 76:1470-1476. https://doi.org/10.1016/j.chemosphere. 2009.07.023

Zhao M, Zhang S, Wang S, Huang H (2012) Uptake, translocation, and debromination of polybrominated diphenyl ethers in maize. J Environ Sci 24:402-409. https://doi.org/ 10.1016/S1001-0742(11)60748-1

Zhao L, Guo W, Zhao W, Long M, Li H (2017a) Effect of three kinds of surfactants and $\beta$-cyclodextrin on the phytoremediation of BDE-209 contaminated sediment. IOP Conf Ser Earth Environ Sci 64:12115. https://doi.org/10.1088/ 1755-1315/64/1/012115

Zhao L, Jiang J, Chen C, Zhan S, Yang J, Yang S (2017b) Efficiency and mechanism of the phytoremediation of decabromodiphenyl ether-contaminated sediments by aquatic macrophyte Scirpus validus. Environ Sci Pollut Res Int 24:12949-12962. https://doi.org/10.1007/s11356017-8900-1

Zhao P, Ye Q, Yu K, Whalen JK, Rajesh Kumar R, Cheng X, Delgado-Moreno L, Wang W (2020) Uptake and transformation of decabromodiphenyl ether in different rice cultivars: evidence from a carbon-14 study. Sci Total Environ 704:135398. https://doi.org/10.1016/j.scitotenv. 2019.135398

Zhou H, Tam NFY, Cheung SG, Wei P, Li S, Wu Q (2019) Contamination of polybrominated diphenyl ethers (PBDEs) in watershed sediments and plants adjacent to e-waste sites. J Hazard Mater 379:120788. https://doi.org/ 10.1016/j.jhazmat.2019.120788

Zhu H, Wang Y, Wang X, Luan T, Tam NFY (2014a) Distribution and accumulation of polybrominated diphenyl ethers (PBDEs) in Hong Kong mangrove sediments. Sci Total Environ 468-469:130-139. https://doi.org/10.1016/j. scitotenv.2013.08.021

Zhu H, Wang Y, Wang X, Luan T, Tam NFY (2014b) Intrinsic debromination potential of polybrominated diphenyl ethers in different sediment slurries. Environ Sci Technol 48:4724-4731. https://doi.org/10.1021/es4053818

Zhu H, Wang Y, Tam NFY (2014c) Microcosm study on fate of polybrominated diphenyl ethers (PBDEs) in contaminated mangrove sediment. J Hazard Mater 265:61-68. https:// doi.org/10.1016/j.jhazmat.2013.11.046 
Zhu C, Li Y, Wang P, Chen Z, Ren D, Ssebugere P, Zhang Q, Jiang G (2015) Polychlorinated biphenyls (PCBs) and polybrominated biphenyl ethers (PBDEs) in environmental samples from Ny-Ålesund and London Island, Svalbard, the Arctic. Chemosphere 126:40-46. https://doi.org/10. 1016/j.chemosphere.2015.01.043

Zhu H, Sun H, Yao Y, Gan Z, Wang Y, Kannan K (2018) Legacy and alternative brominated flame retardants in outdoor dust and pine needles in mainland China: spatial trends, dustplant partitioning and human exposure. Environ Pollut 243:758-765. https://doi.org/10.1016/j.envpol.2018.08. 097
Zhu H, Wang F, Li B, Yao Y, Wang L, Sun H (2020) Accumulation and translocation of polybrominated diphenyl ethers into plant under multiple exposure scenarios. Environ Int 143:105947. https://doi.org/10.1016/j.envint.2020. 105947

Publisher's Note Springer Nature remains neutral with regard to jurisdictional claims in published maps and institutional affiliations. 